\author{
Monograph \\ urn:lsid:zoobank.org:pub:4C9F63B2-DB17-4EDB-ADEE-13AC9EFB921B
}

\title{
Integrative taxonomy of the genus Dyscolus (Coleoptera, Carabidae, Platynini) in Ecuadorian Andes
}

\author{
Pierre MORET $^{1, *} \&$ Jérôme MURIENNE ${ }^{2}$ \\ ${ }^{1}$ Laboratoire TRACES (UMR5608), CNRS, Université Toulouse 2 Jean Jaurès, \\ Toulouse 31058, France. \\ ${ }^{2}$ Laboratoire Evolution et Diversité Biologique (UMR5174), CNRS, Université Toulouse 3 Paul \\ Sabatier, IRD, Toulouse 31062, France. \\ ${ }^{1, *}$ Corresponding author: pierre.moret@univ-tlse2.fr \\ 2Email: jerome.murienne@univ-tlse3.fr \\ ${ }^{1}$ urn:1sid:zoobank.org:author:2E194645-D255-438B-819E-A2B6C39AD699 \\ ${ }^{2}$ urn:lsid:zoobank.org:author:3A6964D4-A7D6-46DB-8129-B762D14BC8F9
}

\begin{abstract}
The genus Dyscolus Dejean, 1831 is a highly speciose taxon of neotropical Carabidae and the major component of high-altitude ground beetle communities in the tropical Andes. The aim of this study is threefold: (i) refine the taxonomic position of the equatorial members of Dyscolus using molecular data, (ii) provide a delimitation of the species found in Ecuador in páramo and montane forest environments based on a robust combination of molecular and morphological data, (iii) describe the new species and take the nomenclatural decisions made necessary by the results of this study. The seclusion of Dyscolus from more basal platynine clades including Platynus, Batenus and Glyptolenus, is supported by a phylogenetic analysis of the COI marker. Twenty-five new species of Dyscolus, most of them microendemic, are described and illustrated: D. aquator Moret sp. nov. (Tandayapa, Pichincha), D. arauzae Moret sp. nov. (Mt Cayambe, Pichincha), D. arborarius Moret sp. nov. (Parque Nacional Yacuri, Loja), D. barragani Moret sp. nov. (Mt Ayapungu, Chimborazo), D. crespoae Moret sp. nov. (Parque Nacional Podocarpus, Zamora-Chinchipe), D. danglesi Moret sp. nov. (Parque Nacional Yacuri, Loja), D. donosoi Moret sp. nov. (Parque Nacional Podocarpus, Zamora-Chinchipe), D. eleonorae Moret sp. nov. (Cotopaxi and Pichincha provinces), D. famelicus Moret sp. nov. (Papallacta, Napo), D. giselae Moret sp. nov. (Reserva Otonga, Cotopaxi), D. globoculus Moret sp. nov. (Parque Nacional Podocarpus, Zamora-Chinchipe), D. gobbii Moret sp. nov. (Guamaní and Mt Antisana, Pichincha), D. incommunis Moret sp. nov. (Tandayapa, Pichincha), D. marini Moret sp. nov. (Parque Nacional Podocarpus, Loja), D. piscator Moret sp. nov. (Guamaní, Napo), D. placitus Moret sp. nov. (Guamaní, Napo), D. ravidus Moret sp. nov. (Parque Nacional Podocarpus, Loja), D. rivinus Moret sp. nov. (Reserva Otonga, Cotopaxi), D. rugitarsis Moret sp. nov. (Parque Nacional Yacuri, Loja), D. ruizi Moret sp. nov. (Parque Nacional Podocarpus, Loja and Zamora), D. salazarae Moret sp. nov. (Parque Nacional Podocarpus, Loja), D. silvestris Moret sp. nov. (Papallacta, Napo), D. sulcipedis Moret sp. nov. (Parque Nacional Yacuri, Loja), D. verecundior Moret sp. nov. (Mt Illiniza and Mt Corazón, Pichincha) and D. verecundissimus Moret sp. nov. (Mt Chimborazo, Chimborazo). Dyscolus palatus Moret, 1998 is newly synonymized with $D$. denigratus (Bates, 1891). We demonstrate the subgenus Hydrodyscolus Moret, 1996 to be polyphyletic and therefore consider it a junior synonym of Dyscolus Dejean, 1831.
\end{abstract}


Keywords. Ground beetles, new species, new synonymy, Ecuador, montane forest, páramo, DNA barcoding.

Moret P. \& Murienne J. 2020. Integrative taxonomy of the genus Dyscolus (Coleoptera, Carabidae, Platynini) in Ecuadorian Andes. European Journal of Taxonomy 646: 1-55. https://doi.org/10.5852/ejt.2020.646

\section{Introduction}

Dyscolus Dejean, 1831 is the most diverse and speciose genus of the ground beetle tribe Platynini in tropical America. Its taxonomic position is still a matter of discussion. From Maximilien de Chaudoir's world-wide revision $(1859,1878)$ to the mid-twentieth century, most neotropical platynines were placed in a huge, pantropical genus Colpodes McLeay, 1825. Moret (1989: 135) and Liebherr (1998) showed that the genus-level name Colpodes is restricted to a small clade of highly distinctive Javanese species and cannot be used in the broad sense of Chaudoir (1878). Whitehead (1973), followed by Liebherr $(1986,1992)$, transferred all the Neotropical Colpodes to the genus Platynus Bonelli, 1810, until then restricted to a moderately diverse lineage of holarctic platynines. However, Moret $(1989,1999)$ argued that characters of submental setation, tarsal morphology and female genitalia made it impossible to include the Neotropical representatives of the former Colpodes complex in the genus Platynus. He removed Dyscolus from synonymy with Colpodes to designate most of the South American platynines previously placed either in Colpodes or in Platynus (Moret 1989). Additionally, five lineages closely related to Dyscolus were isolated in separate genera by Moret or Perrault: Scaphiodactylus Chaudoir, 1838 (Moret 1996), Stenocnemion Moret, 1989 (Moret 1991), Dyscolidion Moret, 1990, Andinocolpodes Perrault, 1990 and Glyptolenopsis Perrault, 1991 (Perrault 1991). At first, these taxonomic changes did not receive wide agreement. All these taxa were treated by Liebherr as species groups within Platynus (Liebherr 1992), whereas Dyscolidion and Glyptolenopsis were considered subgenera of Platynus in Lorenz (2005), and Dyscolus was treated as a subgenus of Platynus in Bousquet (2012b).

A later decisive contribution (Will et al. 2005) showed that the derived condition of male monorchy (i.e., the presence of only one testis) provides evidence for the monophyly of the Colpodes-Dyscolus complex, whereas Platynus shares with other platynine genera a plesiomorphic diorchid condition. Although the taxonomic consequences of this important finding were not explicitly drawn by the authors of this study, the genus name Dyscolus is increasingly used for neotropical platynines of the Colpodes-Dyscolus complex in checklists (Martínez \& Ball 2003; Lorenz 2019) and ecological surveys (Maveety \& Browne 2014). However, the name Platynus has also been used in similar contexts (Camero 2003; Erwin et al. 2015).

This taxonomic uncertainty is all the more problematic since Dyscolus is a hyperdiverse taxon with 445 accepted described species (Lorenz 2019) and several hundreds of undescribed species. Widespread in subtropical and tropical America from Southern United States to northern Argentina, it is the major component of high-altitude ground beetle communities in the equatorial Andes, both in the upper belt of the montane forest above $2000 \mathrm{~m}$ a.s.l. (Maveety \& Browne 2014) and in the tropical alpine páramo ecosystem above $3500 \mathrm{~m}$ a.s.l. (Moret 2005; Gobbi et al. 2018).

The aim of the present study is threefold: (i) refine the taxonomic position of the genus Dyscolus within the tribe Platynini using molecular data; (ii) provide species delimitation for the Ecuadorian highaltitude members of the genus, based on a robust combination of molecular and morphological data; (iii) describe the new species and take the nomenclatural decisions based on the results of the present study. 


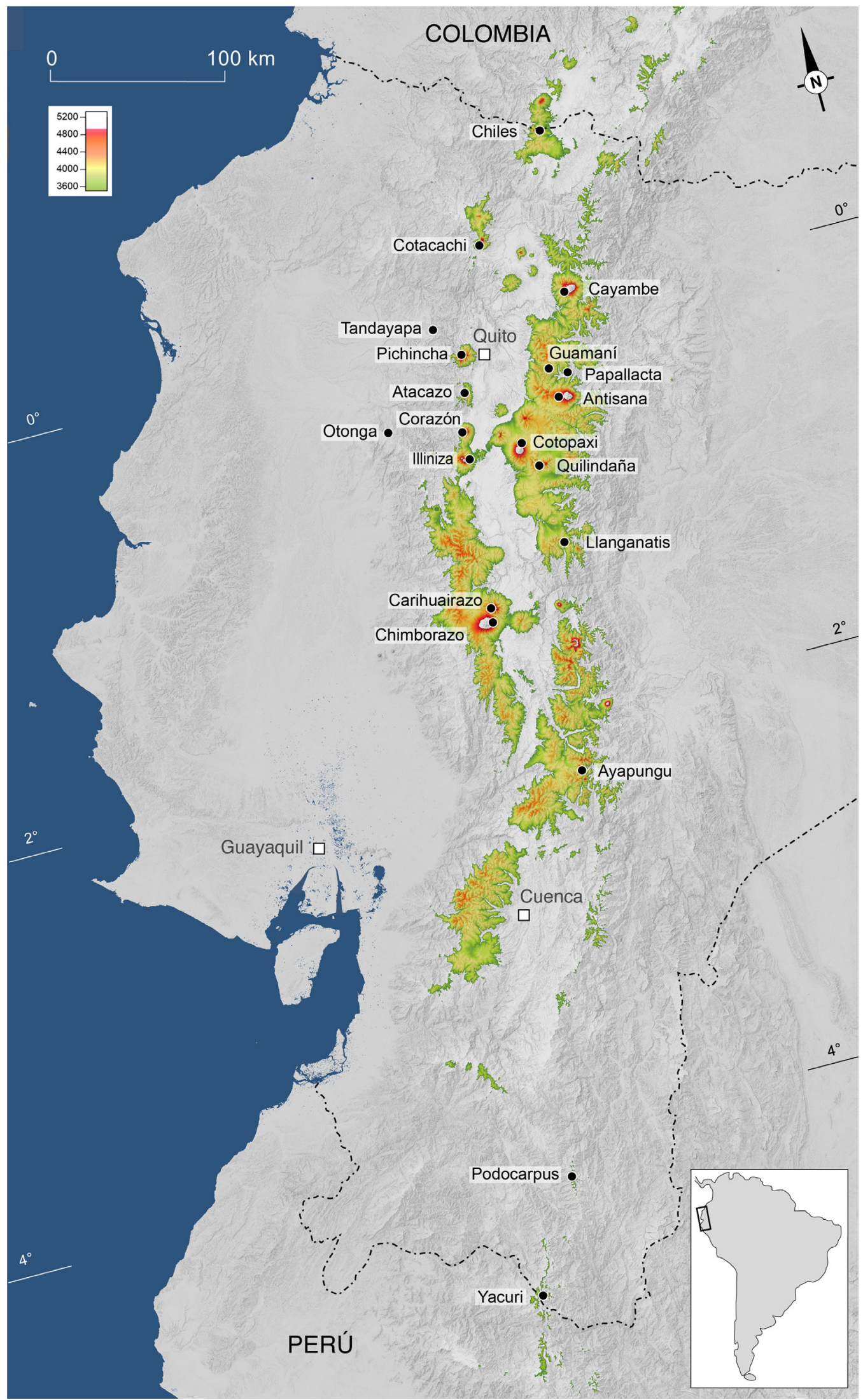

Fig. 1. Map of the Ecuadorian Andes with the localisation of the sampled sites. 


\section{Material and methods}

\section{Sampling}

Around 13800 specimens of carabids were collected between 2015 and 2017 from 17 mountains (mainly volcanoes) of the Andean Cordillera in Ecuador. From north to south (Fig. 1): Volcán Chiles (38004600 m), Volcán Cayambe (3900-4800 m), Volcán Cotacachi (3900-4550 m), Guamaní-Papallacta area (Paso de la Virgen, Termas Jamanco, Guango Lodge, 2700-4350 m), Volcán Antisana (4000-5000 m), Volcán Pichincha (Guagua Pichincha, Rucu Pichincha, 3800-4700 m), Tandayapa-Bellavista Lodge (2000-2100 m), Otonga reserve (1800-2000 m), Volcán Illiniza (4100-4800 m), Volcán Cotopaxi (3700-4900 m), Volcán Quilindaña (4100-4500 m), Llanganatis (Cerro Jaramillo, 4000-4300 m), Volcán Carihuairazo (4200-4800 m), Volcán Chimborazo (4500-5000 m), Ayapungu massif (Cerro Azul, Cerro Pulpito, Cerro Tintillán, 3900-4400 m), Parque Nacional Podocarpus (Estación Cajanuma, Estación El Colibri, 2000-3000 m), Parque Nacional Yacuri (2600-3550 m).

Among this material, 218 specimens identified as Dyscolus were selected for molecular analysis. They were euthanized with ethyl acetate and then immediately stored in $96 \%$ ethanol. After removing one leg for DNA extraction, voucher specimens of the new species were dried, pinned on mounting boards and deposited in public entomological collections (Table 1; further details in the taxonomic section). The vouchers of already described species are kept in $96 \%$ ethanol at Toulouse University. Prior to molecular analyses, specimens were identified to species level following Moret (2005).

\section{Amplification and sequencing}

Total DNA was extracted from one leg. After discarding the ethanol used for fixing the specimens, samples were dried 15 minutes at $70^{\circ} \mathrm{C}$ to ensure complete removal of the ethanol. We used the Macherey Nagel XS kit following manufacturer's protocol. Final elution was performed in $30 \mu \mathrm{L}$ followed by a concentration of 5 minutes at $90^{\circ} \mathrm{C}$ (final volume 15-20 $\mu \mathrm{L}$ ). Purified genomic DNA was used as a template for PCR amplification. The standard 658 base pairs barcode of the mitochondrial proteinencoding gene cytochrome $c$ oxidase subunit I [COI hereafter] was amplified using the primer pair LCO1490 (5' GGT CAA CAA ATC ATA AAG ATA TTG G 3') / HCO2198 (5' TAA ACT TCA GGG TGA CCA AAA AAT CA 3') (Folmer et al. 1994) using the FastStart PCR Master (Roche, Mannheim, Germany). The total PCR volume was $25 \mu \mathrm{L}$ and consisted of $2.5 \mu \mathrm{L}$ of $10 \mathrm{X}$ reaction buffer, $2 \mu \mathrm{L}$ of $10 \mathrm{mM}$ dNTPs, $1.5 \mu \mathrm{L}$ of $25 \mathrm{mM} \mathrm{MgCl}, 1 \mu \mathrm{L}$ of each primer, $8.2 \mu \mathrm{L}$ of $\mathrm{H} 2 \mathrm{O}, 0.2 \mu \mathrm{L}$ of Taq Polymerase and $10 \mu \mathrm{L}$ of template DNA. The PCR cycles were as follow $94^{\circ} \mathrm{C}$ for 4 min, 35 cycles at $94^{\circ} \mathrm{C}$ for $30 \mathrm{~s}, 55^{\circ} \mathrm{C}$ for $30 \mathrm{~s}$ and $72^{\circ} \mathrm{C}$ for $1 \mathrm{~min}$; and then a final extension at $72^{\circ} \mathrm{C}$ for $7 \mathrm{~min}$. The PCR products were verified by capillary migration on a QIAxcel Advanced system (Qiagen) and DNA quantitation was performed using PicoGreen (Turner BioSystems) on an Infinite F400 plate reader (Tecan). The purified PCR products were sequenced directly with the same primer pairs as used for amplification. The sequencing reactions were performed using BigDye Terminator ver. 3.1 (Applied Biosystems). The BigDye-labelled PCR products were purified using Sephadex G-50 medium (Sigma). The sequence reaction products were then analyzed using an ABI Prism 3730xl Genetic Analyzer (Applied Biosystems) by Genoscreen (Lille, France). Forward and reverse sequences were edited and assembled using Geneious 9 (Kearse et al. 2012). The 212 obtained sequences (sequencing failed for six specimens) were uploaded to the Barcode of Life Data Systems (Ratnasingham \& Hebert 2007), and can be found in the BOLD projects "DS-GLYPTO" and "DS-DYSGLYP".

\section{Preliminary molecular analysis}

In order to confirm the monophyly of the genus Dyscolus, we first created a dataset 'DS-GLYPTO' including representatives of all the species of Dyscolus of our dataset as well as specimens of Platynus and other platynine genera. Among the diorchid lineages, we used the following taxa: Platynus (Batenus) hypolithos (Say, 1823) (process ID in BOLD: RRSSA2338-15), Platynus (Batenus) cincticollis (Say, 
1823) (MGOCF068-16), Platynus assimilis (Paykull, 1790) (FBCOA811-10, recorded as Limodromus assimilis) and Platynus decentis (Say, 1823) (BETN168-18). Additional representatives include Agonum decorum (Say, 1823) (COSO475-08), Anchomenus dorsalis (Pontoppidan) (FBCOA710-10), Tanystoma cuyama Liebherr, 1985 (NEONU1755-13), Rhadine lindrothi Barr, 1965 (IUP466-14) and Paranchus albipes (Fabricius, 1796) (FBCOA492-10) from the Nearctic or Palaearctic fauna, as well as members of three neotropical genera: Incagonum aeneum (Reiche, 1843) (SUM068-18), Incagonum andicola (Bates, 1891) (SUM199-18), Glyptolenus apicestriatus (Reiche, 1843) (SUM198-18) and Glyptolenoides azureus (Chaudoir, 1859) (SUM063-18). As representatives of the monorchid Dyscolus complex, we used one specimen per species of our Ecuadorian dataset, plus a selection of Middle and North American species whose barcodes are publicly available in BOLD, including members of the subgenera Dyscolidion and Glyptolenopsis, namely Dyscolus (Dyscolidion) viridiauratus (Bates, 1878) (GMADN010-16, recorded in BOLD as Platynus sp.) and Dyscolus (Glyptolenopsis) ovatulus (Bates, 1884) (NEONU670-11, recorded in BOLD as Platynus ovatulus). This selection also includes North American taxa that have been assigned so far to Platynus, although they share with Dyscolus the derived monorchid character state of the male genitalia: Platynus brunneomarginatus (Mannerheim, 1843) (BBCCA3730-12), P. ovipennis (Mannerheim, 1843) (NEONU1792-13) and P. tenuicollis (LeConte, 1846) (NEONU2053-13). Binomials have been corrected from BOLD original records following the taxonomic arrangement in Lorenz (2019). We used Pterostichus (Cryobius) caribou Ball, 1962 (Pterostichini) as outgroup.

The DS-GLYPTO dataset thus includes 93 specimens, 79 of which are members of the Dyscolus complex. After initial alignment with Muscle (Edgar 2004), a Maximum Likelihood phylogenetic tree was reconstructed using raxml-ng (Kozlov et al. 2019) based on 100 random parsimony starting trees, applying a GTR $+\mathrm{G}$ model and performing an automatic bootstrapping procedure (autoMRE option) using the Transfert Bootstrap Expectation support metric (Lemoine et al. 2018).

\section{Species delimitation}

In the following step of the analysis, we only included representatives of the Dyscolus genus but used all the available sequences, 212, thus including several sequences per nominal species. In addition to our own sequences, we also included nine sequences provided by Carlos Ruiz Carreira, from carabid beetles collected during his project "Estudio de la riqueza de especies y estructura filogenética en comunidades de carábidos a lo largo de un gradiente altitudinal en el Parque Nacional Podocarpus" (Universidad Técnica Particular de Loja, 2013-2014): GBPNP001-17, GBPNP002-17, GBPNP003-17, GBPNP014-17, GBPNP015-17, GBPNP018-17, GBPNP020-17, GBPNP035-17 and GBPNP038-17.

Among the algorithms available for molecular species delimitation, we chose to use a distance-based method that does not rely on ad hoc similarity thresholds and does not require parameters that are difficult to select a priori. We used the REfin Single Linkage clustering approach (RESL; Ratnasingham \& Hebert 2013) as implemented in the Barcoding of Life Data System [BOLD] to define Barcode Index Numbers (BINs) based on our COI dataset. The RESL algorithm has the advantage of using a two-step procedure: an initial clustering at a $2.2 \%$ divergence threshold followed by a refinement step using Markov clustering. In addition, it uses all of the sequences present in the BOLD database for clustering, allowing for a direct comparison of our dataset with sequences produced from other barcoding projects.

\section{Morphological examination and measurements}

Specimens were examined and measured using a Zeiss Stemi 508 trinocular stereo microscope. Photographs were taken with a Zeiss AxioCam 105 microscope camera. Z-series of photographs were stacked using Helicon Focus Software (Helicon Soft Ltd), then enhanced with Photoshop ${ }^{\circ}$. 
Table 1 (continued on next page). Vouchers and genetic sequences of the new species.

\begin{tabular}{|c|c|c|c|}
\hline Species & Voucher specimen & Voucher depository & BOLD process ID \\
\hline Dyscolus aquator & PM081-01 (paratype) & $\mathrm{CPM}$ & SUM213-18 \\
\hline Dyscolus aquator & PM510 (paratype) & OSAC & SUM310-18 \\
\hline Dyscolus arauzae & PM073-03 (paratype) & CPM & SUM020-18 \\
\hline Dyscolus arauzae & PM077-01 (paratype) & CPM & SUM099-18 \\
\hline Dyscolus arborarius & PM170-02 (holotype) & MNHN & SUM191-18 \\
\hline Dyscolus barragani & PM417-02 (paratype) & $\mathrm{CPM}$ & SUM021-18 \\
\hline Dyscolus crespoae & PM402-03 (paratype) & $\mathrm{CPM}$ & SUM188-18 \\
\hline Dyscolus danglesi & PM170-01 (holotype) & MNHN & SUM190-18 \\
\hline Dyscolus donosoi & CR017 (paratype) & CISEC & GBNP014-17 \\
\hline Dyscolus donosoi & CR018 (paratype) & CISEC & GBNP015-17 \\
\hline Dyscolus donosoi & PM402-02 (holotype) & QCAZ & SUM187-18 \\
\hline Dyscolus eleonorae & PM081-03 (paratype) & CPM & SUM014-18 \\
\hline Dyscolus famelicus & PM040-02 (paratype) & $\mathrm{CPM}$ & SUM184-18 \\
\hline Dyscolus giselae & PM513 (paratype) & $\mathrm{CPM}$ & SUM313-18 \\
\hline Dyscolus globoculus & CR064 (holotype) & MNHN & GBNP035-17 \\
\hline Dyscolus gobbii & PM188-01 (paratype) & $\mathrm{CPM}$ & SUM183-18 \\
\hline Dyscolus gobbii & PM210-16 (holotype) & QCAZ & SUM228-18 \\
\hline Dyscolus incommunis & PM081-01 (paratype) & $\mathrm{CPM}$ & SUM214-18 \\
\hline Dyscolus incommunis & PM505 (paratype) & OSAC & SUM305-18 \\
\hline Dyscolus marini & CR029 (paratype) & CISEC & GBNP020-17 \\
\hline Dyscolus marini & PM392-10 (holotype) & QCAZ & SUM057-18 \\
\hline Dyscolus marini & PM397-01 (paratype) & $\mathrm{CPM}$ & SUM248-18 \\
\hline Dyscolus marini & PM399-02 (paratype) & $\mathrm{CPM}$ & SUM189-18 \\
\hline Dyscolus piscator & PM283-01 (paratype) & $\mathrm{CPM}$ & SUM239-18 \\
\hline Dyscolus ravidus & PM397-02 (paratype) & $\mathrm{CPM}$ & SUM058-18 \\
\hline Dyscolus ravidus & PM397-03 (paratype) & $\mathrm{CPM}$ & SUM249-18 \\
\hline Dyscolus rugitarsis & PM167-05 (paratype) & CPM & SUM060-18 \\
\hline Dyscolus ruizi & CR001 (paratype) & CISEC & GBNP001-17 \\
\hline Dyscolus ruizi & CR002 (paratype) & CISEC & GBNP002-17 \\
\hline Dyscolus ruizi & CR003 (paratype) & CISEC & GBNP003-17 \\
\hline Dyscolus ruizi & CR008 (paratype) & CISEC & GBNP006-17 \\
\hline Dyscolus ruizi & CR055 (paratype) & CISEC & GBNP029-17 \\
\hline
\end{tabular}


Table 1 (continued). Vouchers and genetic sequences of the new species.

\begin{tabular}{llll}
\hline Species & Voucher specimen & Voucher depository & BOLD process ID \\
\hline Dyscolus ruizi & CR120 (paratype) & QCAZ & GBNP068-17 \\
Dyscolus ruizi & PM392-68 (holotype) & QCAZ & SUM056-18 \\
Dyscolus salazarae & PM392-09 (holotype) & MNHN & SUM059-18 \\
Dyscolus silvestris & PM041-02 (paratype) & CPM & SUM103-18 \\
Dyscolus silvestris & PM041-06 (paratype) & CPM & SUM104-18 \\
Dyscolus sulcipedis & PM167-09 (paratype) & CPM & SUM061-18 \\
Dyscolus verecundior & PM136-04 (holotype) & CPM & SUM062-18 \\
\hline
\end{tabular}

Body size was measured from the tip of mandibles in closed position to the apex of elytra. The width of the pronotum and elytra was measured at their widest points. The length of the pronotum was measured along the median line. The length of the elytra was measured from the basal bead to the apex of the longer elytron.

\section{Taxonomic treatment}

Following publication procedures aimed at speeding up the description of species in hyperdiverse genera and providing a partial solution to the taxonomic impediment (Butcher et al. 2012; Riedel et al. 2013), we combined concise diagnostic descriptions with DNA-barcoding and high-resolution photographs of type specimens. Morphological descriptions are therefore limited to diagnostic characters allowing a sure separation from any other currently known taxon.

The studied material is housed in the following museums and collections:

CISEC = Colección de Invertebrados del Sur del Ecuador, Universidad Técnica Particular de Loja, Loja, Ecuador

$\mathrm{CMNC}=$ Canadian Museum of Nature Collection, Ottawa, Canada

$\mathrm{CMNH}=$ Carnegie Museum of Natural History, Pittsburgh, Pennsylvania, USA

$\mathrm{CPM}=$ Collection P. Moret, Toulouse University, Toulouse, France

$\mathrm{CPMG}=$ Collection Pier Mauro Giachino, Torino, Italy

MNHN = Muséum national d'histoire naturelle, Paris, France

MZUF = Museo di Storia Naturale, Sezione di Zoologia "La Specola", University of Florence, Italy

OSAC = Oregon State Arthropod Collection, Oregon State University, Corvallis, USA

QCAZ = Museo de Zoología, Pontificia Universidad Católica del Ecuador, Quito, Ecuador

$\mathrm{UASM}=$ Strickland Entomological Museum, University of Alberta, Edmonton, Canada

\section{Results}

\section{Systematic position of Dyscolus}

Even though we acknowledge that a molecular study restricted to COI data might present limited phylogenetic information, our analysis based on a broad taxon sampling (dataset DS-GLYPTO, Fig. 2) confirms morphology-based statement that the genus Dyscolus is only distantly related to Platynus. In particular, our results are congruent with those based on testicular morphology (Will et al. 2005). All the diorchid taxa of our dataset - i.e., those with two testes, which is the plesiomorphic state of this character 


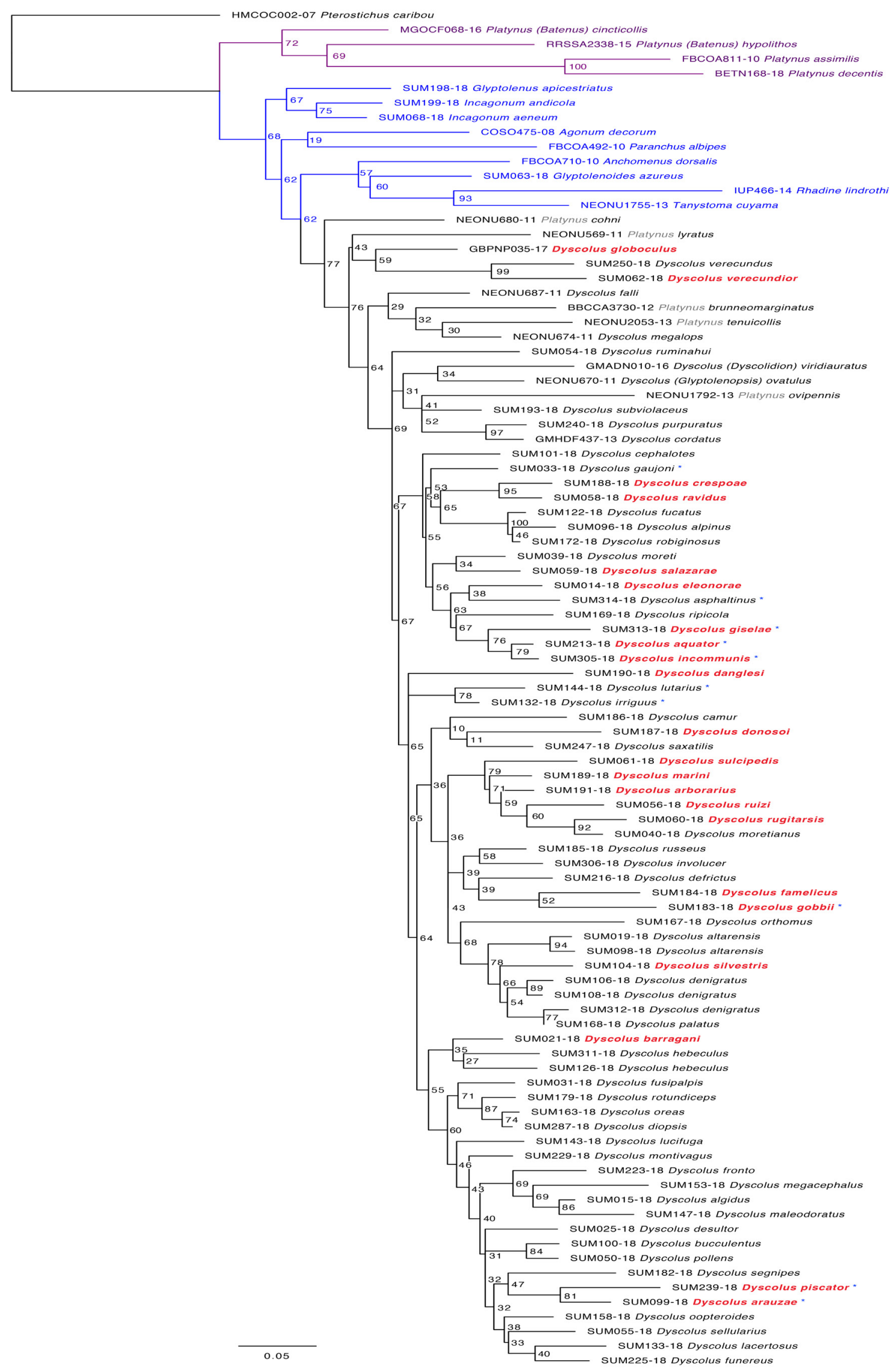


- are grouped at the base of the tree: Platynus, Batenus Motschulsky, 1864, Incagonum Liebherr, 1994, Glyptolenus Bates, 1878, Tanystoma Motschulsky, 1845, Rhadine Le Conte, 1846, Agonum Stephens, 1827 and Anchomenus Stephens, 1827. Taxa with one testis (monorchid lineages) occupy the distal part of the tree, including not only members of Dyscolus and Dyscolus (Glyptolenopsis), but also three North American species identified so far as Platynus in revisions and checklists (Liebherr \& Will 1996; Bousquet 2012a, 2012b; Lorenz 2019): P. brunneomarginatus, P. ovipennis and P. tenuicollis. Together with these three species whose monorchid condition has been experimentally demonstrated (Will et al. 2005), other North American species currently placed in Platynus (Bousquet 2012b) are found far from the Platynus-Batenus clade and close to Dyscolus: P. cohni Liebherr \& Will, 1996, P. falli (Darlington, 1936) [registered as Dyscolus in Lorenz 2019], P. lyratus (Chaudoir, 1879) and P. megalops (Bates, 1882) [registered as Dyscolus in Lorenz 2019].

Platynus in its currently accepted definition thus appears to be polyphyletic. As already suggested (Moret 1989, 1999), Platynus should be restricted to species with only one pair of setae on the submentum and possessing both apical and subapical pairs of setae on the dorsolateral margin of the fourth metatarsomere, as observed in the type species, Platynus assimilis (Paykull, 1790), and in a few related North American species. The species exhibiting a quadrisetose submentum and with only one pair of setae on the dorsolateral margin of the fourth metatarsomere, which is the case of $P$. brunneomarginatus, P. cohni, P. falli, P. lyratus, P. megalops, P. ovipennis and P. tenuicollis in our dataset, should be removed from Platynus. A more comprehensive analysis is needed to find out if all of these species can fit into a broadly defined genus Dyscolus, or if some of them should be placed in another taxon (an option could be Scaphiodactylus, as defined in Moret 1999). We therefore decided not to modify the binomials retrieved from Lorenz (2019) in our phylogenetic tree (Fig. 2).

With regard to the other platynine genera included in our analysis, it should be noted that Glyptolenus and Glyptolenoides are found in different branches, which suggests that the shared derived character of externally canaliculate foretibiae is likely to be a homoplasy. Conversely, Incagonum appears to be closely related to Glyptolenus, rather than to the Rhadine-Tanystoma lineage as previously hypothesized (Liebherr 1994). The melanistic base of the male genitalia, a character shared by Incagonum and Glyptolenus, is likely to give a morphological support to this relationship.

\section{Subgeneric divisions of Dyscolus}

Our results show that representatives of the supraspecific taxa Dyscolidion (GMADN010-16) and Glyptolenopsis (NEONU670-11) are nested within the Dyscolus clade. These positions are compatible with their current treatment as subgenera of Dyscolus (Lorenz 2019). More research is needed to determine whether they should be maintained as subgenera or downgraded to species groups. The supraspecific taxon Stenocnemion could not be included in this study, as no specimens preserved in pure ethanol were available. However, the monorchid condition of at least one Central American Stenocnemion species (Will et al. 2005) suggests that this lineage, defined by two highly distinctive synapomorphies (parascutellar area of elytron bisetose and ventral face of female gonocoxite plurisetose), can be provisionally treated as a subgenus of Dyscolus (Moret 2019).

Ten species of the studied dataset fit the definition of the subgenus Hydrodyscolus: head large with long and acute mandibles, fourth metatarsomere lacking dorsolateral setae but with a dense ventral

Fig. 2 (opposite page). Maximum Likelihood phylogenetic tree of the DS-GLYPTO dataset. Bootstrap support values are indicated on nodes. Purple: the Platynus clade; blue: other platynine lineages; black: the Dyscolus complex. The names of the new species are in bold red. Names with an asterisk refer to species fitting the definition of the subgenus Hydrodyscolus Moret, 1996 (herein synonymised with Dyscolus Dejean, 1831). 
pubescence, riparian way of life. These species turned out to be scattered in five different clades: i/ D. irriguus Moret, 2005 and D. lutarius Moret, 2005; ii/ D. gobbii Moret sp. nov. (pp. 40-42); iii/ D. arauzae Moret sp. nov. and D. piscator Moret sp. nov. (pp. 36-40); iv/ D. asphaltinus (Chaudoir, 1878), D. aquator Moret sp. nov., D. giselae Moret sp. nov. and D. incommunis Moret sp. nov. (pp. 1318); v/ D. gaujoni (Perrault, 1989). Even though COI barcoding does not provide sufficient support to resolve the relationships between species groups within the genus Dyscolus, the mentioned combination of characters appears to be homoplasic. As the loss of the dorsolateral setae is associated in most species with an increasing density and length of the ventral pubescence, it can be assumed that this modification of the tarsal morphology is an adaptive character, related to the capacity of riparian species to move on or in the water. Similarly, the lengthening of the mandibles could be related to the habit of feeding on aquatic arthropods or crustaceae (personal observation in Ecuador, Ayapungu, $4180 \mathrm{~m}$ a.s.l.; 24 Mar. 2015: an adult of D. irriguus plunging his head into the water to capture an amphipod of the genus Hyalella). Accordingly, the subgenus Hydrodyscolus appears to be polyphyletic and we therefore propose to treat it as a junior synonym of Dyscolus.

\section{Taxonomic descriptions}

Class Insecta Linnaeus, 1758

Order Coleoptera Linnaeus, 1758

Family Carabidae Latreille, 1802

Subfamily Harpalinae Bonelli, 1810

Tribe Platynini Bonelli, 1810

Genus Dyscolus Dejean, 1831

Dyscolus Dejean, 1831: 437. Type species: Dyscolus memnonius Dejean, 1831, by subsequent designation (Chaudoir 1878: 343).

Hydrodyscolus Moret, 1996: 498. syn. nov.

Dyscolus - Moret 1989: 143.

The revision of the sequenced species led us to re-examine related material and to describe three new species of which we do not have DNA data, but which can be readily separated from the sequenced taxa (Dyscolus placitus Moret sp. nov., D. rivinus Moret sp. nov. and D. verecundissimus Moret sp. nov.).

All the species under study share the following characters, which are, therefore, not repeatedly mentioned in the descriptions of the new species: labrum with six setae near apical margin; clypeus with two pairs of setae; two supraorbital setae each side; mentum with one pair of setae, submentum with two pairs of setae (except in the species of the hirsutus and verecundus groups, which may have additional submental setae); pronotum with two pairs of lateral setae, the distal one located near the widest point of pronotum, the basal one near or at the laterobasal angle (except $D$. donosoi Moret sp. nov. which lacks the basal seta); parascutellar setiferous pore present; metathoracic wings reduced and metepisternum very short (except in D. eleonorae Moret sp. nov.).

The order in which these 25 new species are presented below is based on broad biogeographic and ecological groupings and on resemblances in external morphology, in order to make comparisons and identifications easier. The five resulting sections are: 1/ full-winged montane forest species (pp. 11-13); 2 / riparian wingless species of the montane forest (pp. 13-18); 3/ wingless, non-riparian species of the montane forest (pp. 18-36); 4/ riparian species of the páramo (pp. 36-42); 5/ non-riparian species of the páramo (pp. 42-51).

All the new species are authored by P. Moret. 


\title{
1. Full-winged montane forest species
}

\author{
Dyscolus eleonorae Moret sp. nov. \\ urn:lsid:zoobank.org:act:D54E7BCD-E9AB-464C-8A97-C140D4E42D80
}

Figs 3-4

\section{Etymology}

Noun in the genitive case, dedicated to Éléonore Deysson.

\section{Type material}

\section{Holotype}

ECUADOR • \} \text { ; Cotopaxi Province, San Francisco de las Pampas, Dos Ríos; } 2 0 0 0 \text { m a.s.l.; Feb. 1993; } L. Bartolozzi leg.; num. mag. 1406; QCAZ.

Paratypes $(11 \hat{\delta}, 10$ 우)

ECUADOR - Pichincha Province - 1 \%; Tandayapa, Bellavista Lodge, Waypoint 81; $0^{\circ} 0^{\prime} 56.6^{\prime \prime} \mathrm{S}$, 78 40'49.1" W; $2250 \mathrm{~m}$ a.s.1.; 2 Nov. 2015; P. Moret leg.; COI voucher PM081-03, BOLD sequence SUM014-18; CPM • 1 đ̃, 1 क; 19 km NW of Nono; 2500 m a.s.l.; Mar. 1976; J.M. Campbell leg.; UASM - 1 ô; Mindo; 7 Aug. 1994; Ohio University leg.; QCAZ • 1 + ; Río Guajalito; 0¹3'53" S, 78 48'10" W; 1800 m a.s.1.; 23 Apr. 2005; A. Rodríguez leg.; QCAZ $10247 \bullet 1$ ơ; same collection data as for preceding; 17 Apr. 2010; A. León leg.; QCAZ 256855. - Santo Domingo Province • 1 đ; Santa Domingo; Nov. 1981; G. Onore leg.; CPM • 1 क ; same collection data as for preceding; QCAZ. - Cotopaxi Province • 1 ó; San Francisco de las Pampas; 1300-1500 m a.s.1.; Feb. 1993; Num. mag. 1406, L. Bartolozzi leg.; MZUF • 1 क; Otonga, río Las Damas; 1800 m a.s.1.; 3-5 Jul. 2001; P. Moret leg.; on vegetation $2 \mathrm{~m}$ above ground; CPM 11 ऊ; Otonga; $1800 \mathrm{~m}$ a.s.l.; 20 Oct. 2000; I.G. Tapia leg.; QCAZ • 1 O; same collection date as for preceding; MNHN • 1 क ; Otonga; $0^{\circ} 25^{\prime} 16.5^{\prime \prime} \mathrm{S}, 7^{\circ} 0^{\prime} 9^{\prime \prime} \mathrm{W}$; 1961 m a.s.1.; 14 Nov. 2007; A.C. Proaño and A. Barragán leg.; CPMG • 1 q; Otonga; 1 Jan. 1997; G. Onore leg.; QCAZ 1 § ; Otonga; 1800 m a.s.1.; 5 Nov. 1992; G. Onore leg.; CMNH • 1 §; Otonga; $0^{\circ} 25^{\prime} \mathrm{S}, 79^{\circ} 0^{\prime} \mathrm{W}$; $1975 \mathrm{~m}$ a.s.1.; 11 Jul. 2007; A.C. Proaño leg.; QCAZ $74255 \bullet 1$ \&; Otonga; $2000 \mathrm{~m}$

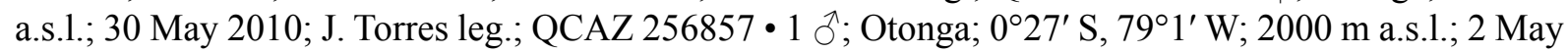
1997; L. Timpe leg.; CPM • 1 क ; Otonga; $0^{\circ} 19^{\prime} 11^{\prime \prime} \mathrm{S}, 7^{\circ} 57^{\prime} 0^{\prime \prime} \mathrm{W} ; 1600 \mathrm{~m}$ a.s.1.; 2 Jul. 2000; A. Pérez leg.; QCAZ • 1 § ; Los Libres; 2000 m a.s.1.; 5 Nov. 1994; S. Espinosa leg.; QCAZ. - El Oro Province • 1 Tे; 9 km NW Atahualpa; 1860 m a.s.1.; 5 Nov. 1987; J. Rawlins, C. Young and R. Davidson leg.; cloud forest; $\mathrm{CMNH}$.

\section{Diagnostic description}

Habitus: Fig. 3. Fully winged. Body length: $10.8-13.7 \mathrm{~mm}$. Shiny black with a strong metallic iridescence on the elytra, legs dark brown to piceous black, antennomeres brownish with the basal third reddish brown, mouthparts dark brown. Head constricted basally, vertex convex, eyes big, genae short. Pronotum broader at base than at apex, sides arcuate, hind angles rounded, laterobasal impressions deeply impressed; two pairs of lateral setae. Elytra convex, subparallel, humeri broadly bulging, striae finely punctate, intervals flat to slightly convex; third interval with three setae, the second one after the middle, the third one near apex; a marked protuberance at the beginning of apical third along intervals 7 and 8; subapical sinuation deep; each elytron with a separate, rounded apical extension. Last visible abdominal ventrite with one pair $\left({ }^{\Uparrow}\right)$ or two pairs $(+$ ) $)$ of setae along its apical margin. Legs thin; fourth metatarsomere with a subapical dorsolateral seta only on the inner lobe, apical lobes elongate, parallel, asymmetrical, the outer lobe 2.5 times longer than the inner lobe. Male genitalia: Fig. 4. Median lobe short, stout, with a short apex; endophallus densely spiculate, with longer and more sclerotized spikes at apex. Female genitalia: unstudied. 

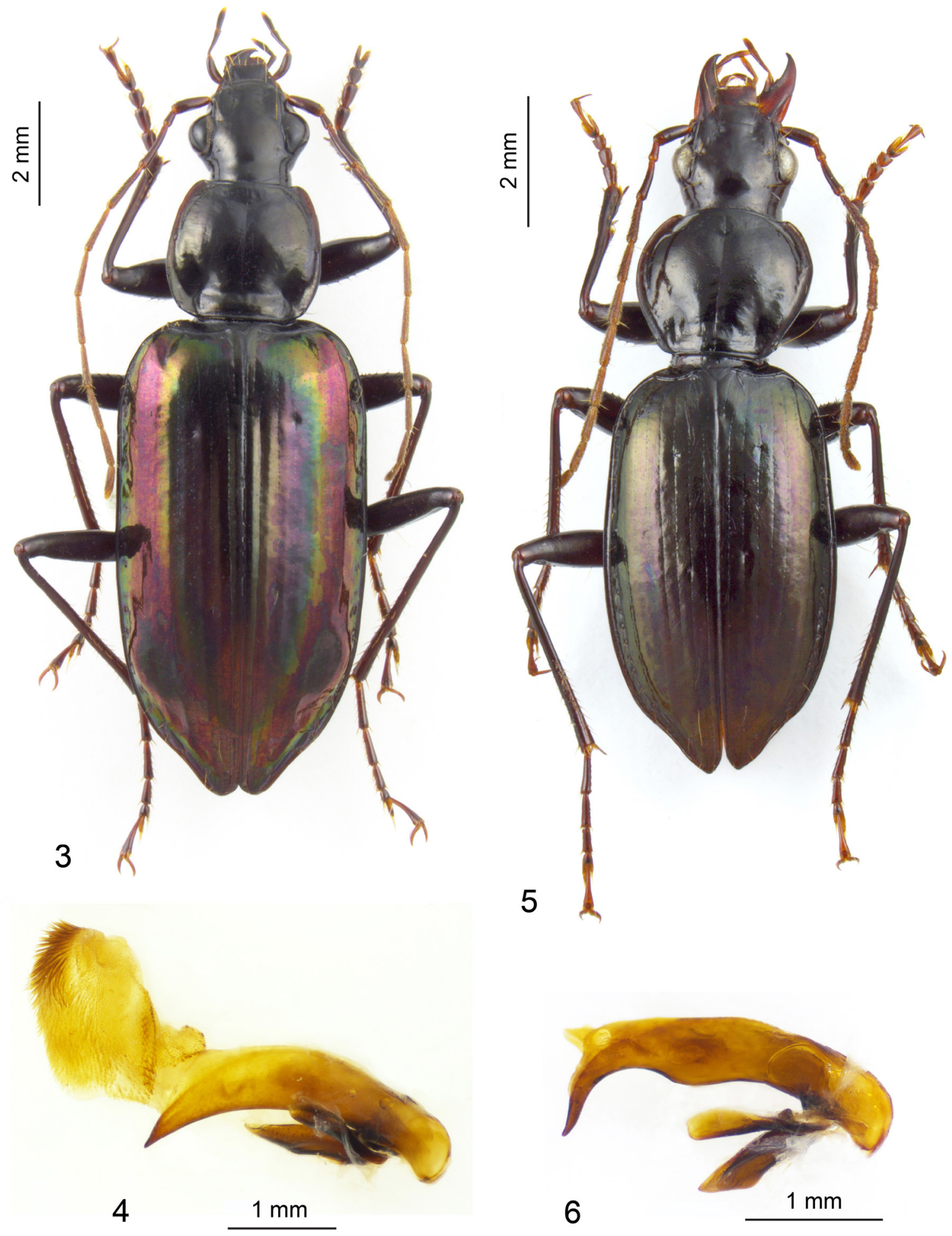

Figs 3-6. 3-4. Dyscolus eleonorae Moret sp. nov. 3. Habitus of the male holotype (QCAZ). 4. Aedeagus, median lobe in lateral view. 5-6. D. giselae Moret sp. nov. 5. Habitus of the male holotype (QCAZ). 6. Aedeagus, median lobe in lateral view. 


\section{Comparisons}

The asymmetrical lobes of the fourth metatarsomere, with one dorsolateral seta on the inner lobe and none on the outer lobe, are similar to those in the subgenus Dyscolidion Moret, 1990. However, in Dyscolidion the dorsolateral seta has an apical position, while in this species it is subapical, and the DNA barcoding does not suggest a phyletic proximity to Dyscolus (Dyscolidion) viridiauratus (Bates, 1878) [Process ID in BOLD: GMADN010-16, recorded as Platynus sp.].

\section{Habitat}

Humid montane forest, from 1300 to $2500 \mathrm{~m}$ a.s.l. Probably arboreal. One of the paratypes has been observed sitting on a leave of the lower vegetation stratum, during the day (personal observation at the Otonga Reserve).

\section{Geographic distribution}

Pacific slope of the Western Cordillera throughout Ecuador. Most specimens were collected at the latitude of Quito, but one paratype is from the southernmost part of the country (El Oro Province). Possibly present across the border in southern Colombia. The record from Chone, in a drier environment in the coastal lowlands of the Manabí Province, is doubtful.

\section{Riparian wingless species of the montane forest}

Dyscolus giselae Moret sp. nov. urn:1sid:zoobank.org:act:235B5F1A-B526-4F29-BB49-0C16A08A5218

Figs 5-6

\section{Etymology}

Noun in the genitive case, dedicated to Gisèle Moret-Deysson.

\section{Type material}

\section{Holotype}

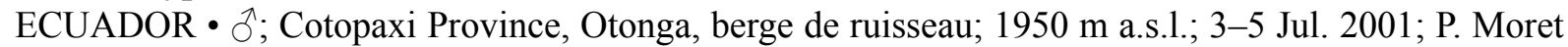
leg.; QCAZ.

\section{Paratypes $(9 \hat{\jmath} \widehat{\partial}, 13$ 우)}

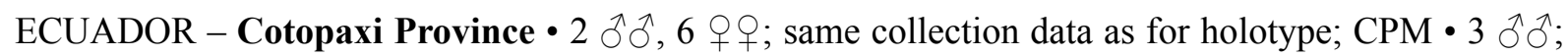

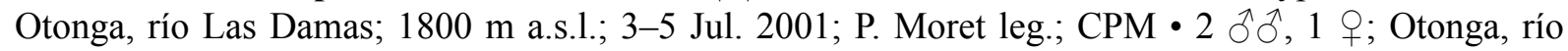
Esmeraldas; 1800 m a.s.1.; 3-5 Jul. 2001; P. Moret leg.; CPM • 1 +; Otonga; 2000 m a.s.1.; 1 May 1997; J. Gil leg.; "debajo de piedras en río"; QCAZ • 1 ð̌; Las Pampas, Otonga; 1 Jan. 1997; G. Onore leg.; QCAZ • 1 क; Otonga; 1900 m a.s.l.; 7 Aug. 1998; I. Tapia leg.; QCAZ・1 ठ; Otonga, río Esmeraldas; $0^{\circ} 25.455^{\prime} \mathrm{S}, 79^{\circ} 00.360^{\prime} \mathrm{W} ; 1883 \mathrm{~m}$ a.s.1.; 13 Aug. 2016; V. Crespo leg.; COI voucher PM513, BOLD sequence SUM313-18; CPM • 3 우; Cantón Sigchos, Las Pampas, Bosque Integral Otonga; 11-12 Jul. 2007; W. Rossi leg.; CPMG • 1 क; San Francisco de las Pampas, Otonga; 30 Jul. 2004; G. Caoduro and G. Avesani leg.; CPMG.

\section{Diagnostic description}

Habitus: Fig. 5. Wingless. Body length: 10.2-12.2 mm. Shiny, piceous black with a faint metallic lustre on the elytra, varying from dark green to copper or pink; legs dark brown, antennae and mouthparts reddish brown to brownish. Elytral microsculpture transverse, shallowly impressed. Head broad, convex, eyes bulging, mandibles long and acute. Pronotum convex, rounded, much narrower at base 
than at apex, not sinuate, hind angles very obtuse, almost rounded; two pairs of lateral setae. Elytra elongate, convex, base narrow, humeri effaced; striae shallowly impressed, finely punctate, intervals flat to subconvex; third interval with three setae, except one male paratype that bears five setae on each side; subapical sinuation deep; apical extension triangular, recurved dorsally, more or less acute at apex. Last visible abdominal ventrite with one pair $\left({ }^{\Uparrow}\right)$ or two pairs ( + ) of setae along its apical margin. Legs moderately slender; fourth metatarsomere without subapical dorsolateral setae, apical lobes parallel, the outer lobe 1.9 times longer than the inner lobe. Male genitalia: Fig. 6. Median lobe swollen in its middle part, abruptly bent ventrally in distal fourth; apical blade long and sinuate in lateral view; endophallus without sclerotized structure. Female genitalia: unstudied.

\title{
Comparisons
}

Metallic coloration and apically subspinose elytra separate $D$. giselae Moret sp. nov. from all the species (previously placed in the subgenus Hydrodyscolus) which share the derived character of a dorsally asetose fourth metatarsomere.

\section{Habitat}

Riparian in the montane forest on the Western slope of the Andes, at around 1800-2000 m a.s.l.

\section{Geographic distribution}

Southern end of the Chocó biogeographic region in northwestern Ecuador. Only known from the type locality, probably microendemic.

\author{
Dyscolus aquator Moret sp. nov. \\ urn:1sid:zoobank.org:act:0CB9ECC0-83A7-4D5D-BCC5-18118ABFAD0F
}

Figs $7-8$

\section{Etymology}

Latin adjective meaning 'related to water'.

\section{Type material}

\section{Holotype}

ECUADOR - O'; Pichincha Province, Tandayapa, Bellavista Lodge, Waypoint 81; $0^{\circ} 0^{\prime} 56.6^{\prime \prime} \mathrm{S}$, 7840'49.1" W; 2250 m a.s.1.; 2 Nov. 2015; P. Moret leg.; QCAZ.

Paratypes $(3 \hat{\partial} \widehat{\partial}, 4 \stackrel{+}{\theta})$

ECUADOR - Pichincha Province -1 ; ; same collection data as for holotype; CPM • 1 क ; same collection data as for holotype; MNHN 1 O ; same collection data as for holotype; COI voucher PM08101, BOLD sequence SUM213-18; CPM - $2 \widehat{\jmath}, 1$ \%; Pichincha Province, Tandayapa, Bellavista, Cascada; UTM 0758443, 9998631; 2100 m a.s.1.; 25 Feb. 2010; P. Moret leg.; under stone; CPM • 1 O; Tandayapa, Bellavista Lodge; $0.0147^{\circ} \mathrm{S}, 78.6833^{\circ} \mathrm{W} ; 2200 \mathrm{~m}$ a.s.l.; 9 Nov. 2010; D. Maddison leg.; COI voucher PM510, BOLD sequence SUM310-18; OSAC.

\section{Diagnostic description}

Habitus: Fig. 7. Wingless. Body length: 10.2-11.9 mm. Body shiny black; basal $3 / 4$ of the femora and basal $1 / 2$ of the tibiae dark brown; rest of the legs, antennae and mouthparts reddish brown. Elytral microsculpture transverse. Head average, eyes moderately bulging, mandibles long and acute. Pronotum elongate, cordiform, hind angles right angled, sharp; two pairs of lateral setae. Elytra narrow, humeri wholly effaced, striae deep, entire, with traces of punctation; third interval with three setae in most 
specimens (four setae on both elytra of one paratype and on the right elytron of another); subapical sinuation very deep; apex with a small acute tooth at sutural angle. Last visible abdominal ventrite with one pair $(\widehat{)})$ or two pairs () of setae along its apical margin. Legs slender; fourth metatarsomere without subapical dorsolateral setae, apical lobes parallel, the outer lobe 1.5 times longer than the inner lobe. Male genitalia: Fig. 8. Middle section of the median lobe straight in lateral view, feebly arcuate distally, apex triangular in lateral view, very short; endophallus without sclerotized structure, except for a subapical denticle. Female genitalia: unstudied.

\section{Comparisons}

See below under D. incommunis Moret sp. nov.

\section{Habitat}

Riparian in the montane forest on the Western slope of the Andes, at around 2200-2250 m a.s.l. The $2100 \mathrm{~m}$ elevation indicated on the labels of the specimens collected in 2010 is wrong, the correct elevation is $2200 \mathrm{~m}$.

\section{Geographic distribution}

Southern end of the Chocó biogeographic region in northwestern Ecuador. Only known from the type locality, probably microendemic.

Dyscolus incommunis Moret sp. nov. urn:Isid:zoobank.org:act:696C59CA-E6A8-46CA-847F-CD9DA0167F60

Figs 9-10

\section{Etymology}

Latin adjective meaning 'not together, not in common'; alluding to the fact that this species is not identical to D. aquator Moret sp. nov., despite the results of BIN analysis.

\section{Type material}

\section{Holotype}

ECUADOR - Ô; Pichincha Province, Tandayapa, Bellavista Lodge, Waypoint 81; $0^{\circ} 0^{\prime} 56.6^{\prime \prime} \mathrm{S}$, $78^{\circ} 40^{\prime} 49.1^{\prime \prime}$ W; 2250 m a.s.1.; 2 Nov. 2015; P. Moret leg.; bromeliad fallen on the ground; QCAZ.

\section{Paratypes $(2 \precsim ふ)$}

ECUADOR - Pichincha Province - 1 ते; same collection data as for holotype; leaf litter at night; COI voucher PM081-02, BOLD sequence SUM214-18; CPM • 1 đ; Tandayapa, Bellavista Lodge; $0.0147^{\circ} \mathrm{S}, 78.6833^{\circ} \mathrm{W} ; 2200 \mathrm{~m}$ a.s.l.; 9 Nov. 2010; D. Maddison leg.; COI voucher PM505, BOLD sequence SUM305-18; OSAC.

\section{Diagnostic description}

Habitus: Fig. 10. Wingless. Body length: $9.6-10.7 \mathrm{~mm}$. Shiny piceous black, femora dark brown, the rest of the legs, antennae and mouthparts reddish brown. Elytral microsculpture transverse. Eyes moderately bulging, genae flat, mandibles long and acute. Pronotum convex, relatively big, elongate, narrowed backward but not cordiform; sides slightly sinuate posterad, hind angles obtuse and blunt; two pairs of lateral setae. Elytra elongate, humeri obliquely sloped, striae entire, finely impressed, with slight traces of punctation; third interval with three setae; subapical sinuation moderate; apical area triangle-shaped, rounded at apex. Last visible abdominal ventrite with one pair ( $\delta$ ) or two pairs (ㅇ) of setae along its apical margin. Legs slender; fourth metatarsomere with or without subapical dorsolateral setae (one seta 
is present on the external lobe of the paratype), apical lobes parallel, the outer lobe 1.5 times longer than the inner lobe. Male genitalia: Fig. 9. Median lobe evenly arcuate, apex finely acute and slightly sinuate in lateral view, apex of the endophallus with a sclerotized structure formed of scales and denticles. Female genitalia: unstudied.

\section{Comparisons}

Although the BIN analysis suggests that D. aquator Moret sp. nov. and D. incommunis Moret sp. nov. are conspecific, the latter is differentiated from the former by important and stable morphological characters: sides of the pronotum less sinuate with obtuse hind angles; elytra broader and more convex, humeri not completely effaced, subapical sinuation weak, no apical tooth. The aedeagus' median lobe is more arcuate, with a shorter apex and a sclerotized area differently shaped in the endophallus. Both species are sympatric in their type locality (Bellavista Lodge), but they live in different habitats.

\section{Habitat}

Montane forest on the Western slope of the Andes, at around $2250 \mathrm{~m}$ a.s.l. Unlike its closest relatives, this species has been collected on the forest ground, far from any stream, in the leaf litter and in fallen bromeliads.

\section{Geographic distribution}

Southern end of the Chocó biogeographic region in northwestern Ecuador. Only known from the type locality, probably microendemic.

Dyscolus rivinus Moret sp. nov. urn:1sid:zoobank.org:act:95AF0791-2EC1-42FD-862D-02F7BCFB1419

Figs $11-12$

\section{Etymology}

Latin adjective meaning 'riparian'.

\section{Type material}

\section{Holotype}

ECUADOR • ${ }^{\text {; }}$; Cotopaxi Province, Otonga; 2000 m a.s.1.; 7 Jul. 1998; I. Tapia leg.; QCAZ.

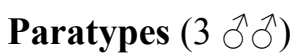

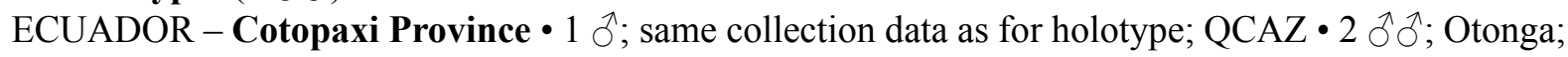
1950 m a.s.1.; 3-5 Jul. 2001; P. Moret leg.; berge de ruisseau; CPM.

\section{Diagnostic escription}

Wingless. Body length: 10.0-11.7 mm. Very similar externally to $D$. incommunis Moret sp. nov., from which it differs in the following features. Base of the pronotum narrower, lateral margins less expanded near base, hind angles more obtuse and more rounded. Apex of elytra ended with a small but protruding and acute tooth, preceded externally by a short sinuation (Fig. 11). Fourth metatarsomere without subapical setae. Male genitalia (Fig. 12) with apex of the median lobe shorter, less acute, not sinuate in lateral view, endophallus unarmed, without a dense squamose area near apex, at most with a single feebly sclerotized squama. Female genitalia unknown. 

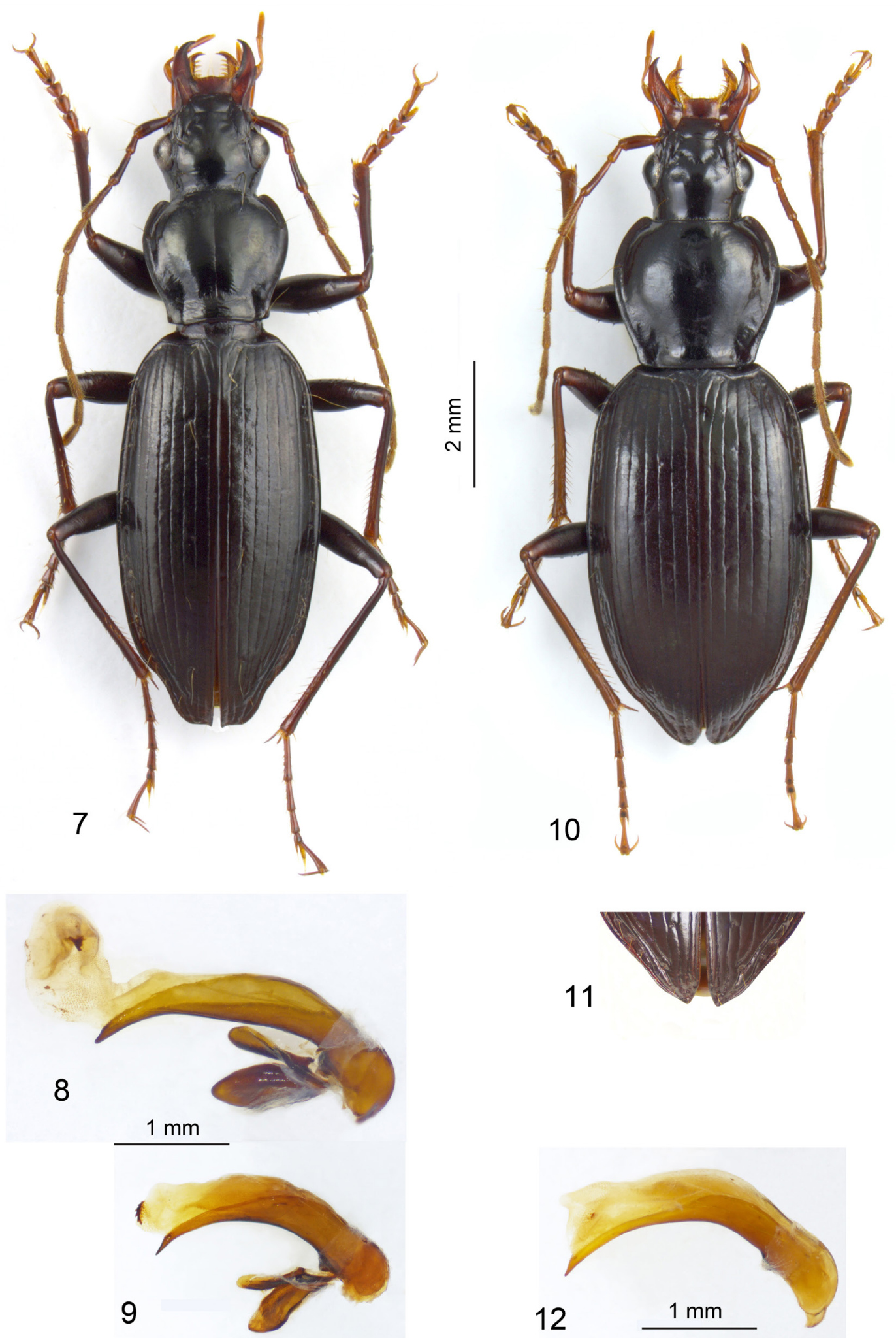

Figs 7-12. 7-8. Dyscolus aquator Moret sp. nov. 7. Habitus of the male holotype (QCAZ). 8. Aedeagus, median lobe in lateral view. 9-10. D. incommunis Moret sp. nov. 9. Aedeagus, median lobe in lateral view. 10. Habitus of the male holotype (QCAZ). 11-12. D. rivinus Moret sp. nov. 11. Apex of the elytra. 12. Aedeagus, median lobe in lateral view. 


\title{
Comparisons
}

Closely related to $D$. incommunis Moret sp. nov., from which it can be distinguished by a few but constant characters, especially the rounded hind angles of the pronotum, the apical tooth of the elytra and the unarmed endophallus.

\section{Habitat}

Riparian in the montane forest on the Western slope of the Andes, at around 1900-2000 m a.s.l. This hygrophile specialisation differs from the more mesic habitat of $D$. incommunis Moret sp. nov.

\section{Geographic distribution}

Southern end of the Chocó biogeographic region in northwestern Ecuador, $75 \mathrm{~km}$ south of the type locality of $D$. incommunis Moret sp. nov. Probably microendemic.

\section{Wingless, non-riparian species of the montane forest}

\author{
Dyscolus globoculus Moret sp. nov. \\ urn:1sid:zoobank.org:act:BDCC6B63-F8CC-4438-8CB3-C7458BCC9715
}

Figs 13-14

\section{Etymology}

Combination of two Latin words, 'globus' and 'oculus', in allusion to the globular form of the eyes of this new species.

\section{Type material}

Holotype (only known specimen)

ECUADOR $-\widehat{o}$ (lacks the left middle leg, the left hind leg and the three last joints of the right antenna); Zamora-Chinchipe Province, Parque Nacional Podocarpus, Bajada Carretera Loja-Zamora; $3.987^{\circ} \mathrm{S}$, 79.118 ${ }^{\circ}$ W; 2530 m a.s.1.; 5 Sep. 2013; D. Marín and C. Ruiz leg.; COI voucher CR064, BOLD sequence GBNP035-17; MNHN.

\section{Diagnostic description}

Habitus: Fig. 13. Wingless. Body length: $12.2 \mathrm{~mm}$. Body shiny black, with a bluish-violaceous metallic lustre on the elytra; femora and tibiae black, tarsi dark brown; palpi reddish brown, antennomeres 1-3 nigropiceous with a darker apex, 4-11 reddish brown. Elytral microsculpture transverse. Head small, very elongate, almost cylindrical, with an abrupt collar constriction; eyes strongly protruding, almost hemispherical; genae long and flat, longer than the eyes; mandibles moderately long and acute. Pronotum almost as wide as the elytra, completely rounded basally, with broadly explanate margins and lacking anterior lobes; two pairs of lateral setae; longitudinal basal impressions narrow. Elytra elongate-oval, convex; humeri effaced; subapical sinuation weak; apex separately rounded. Striae deep and punctate, randomly broken by a few interruptions in the distal part of striae 1-4 and all along striae 5-7. Intervals 1-7 strongly convex, the third interval with two discal setae, one after the middle at ca 0.60 of the elytron length, the other in a broader fovea at $0.85 ; 17$ umbilicate setae along the lateral margin. Last visible abdominal ventrite emarginate, with one pair $\left({ }^{\star}\right)$ of setae along its apical margin. Legs elongate and slender; fourth metatarsomere with one pair of subapical dorsolateral setae (the outer seta has fallen out but the pore is clearly visible), apical lobes asymmetrical, the outer lobe more than two times longer than the inner lobe; fifth tarsomere of all legs setose ventrally. Male genitalia: Fig. 14. Median lobe relatively short, feebly arcuate, apex broadly rounded in dorsal view, endophallus unarmed. Female genitalia: unknown. 


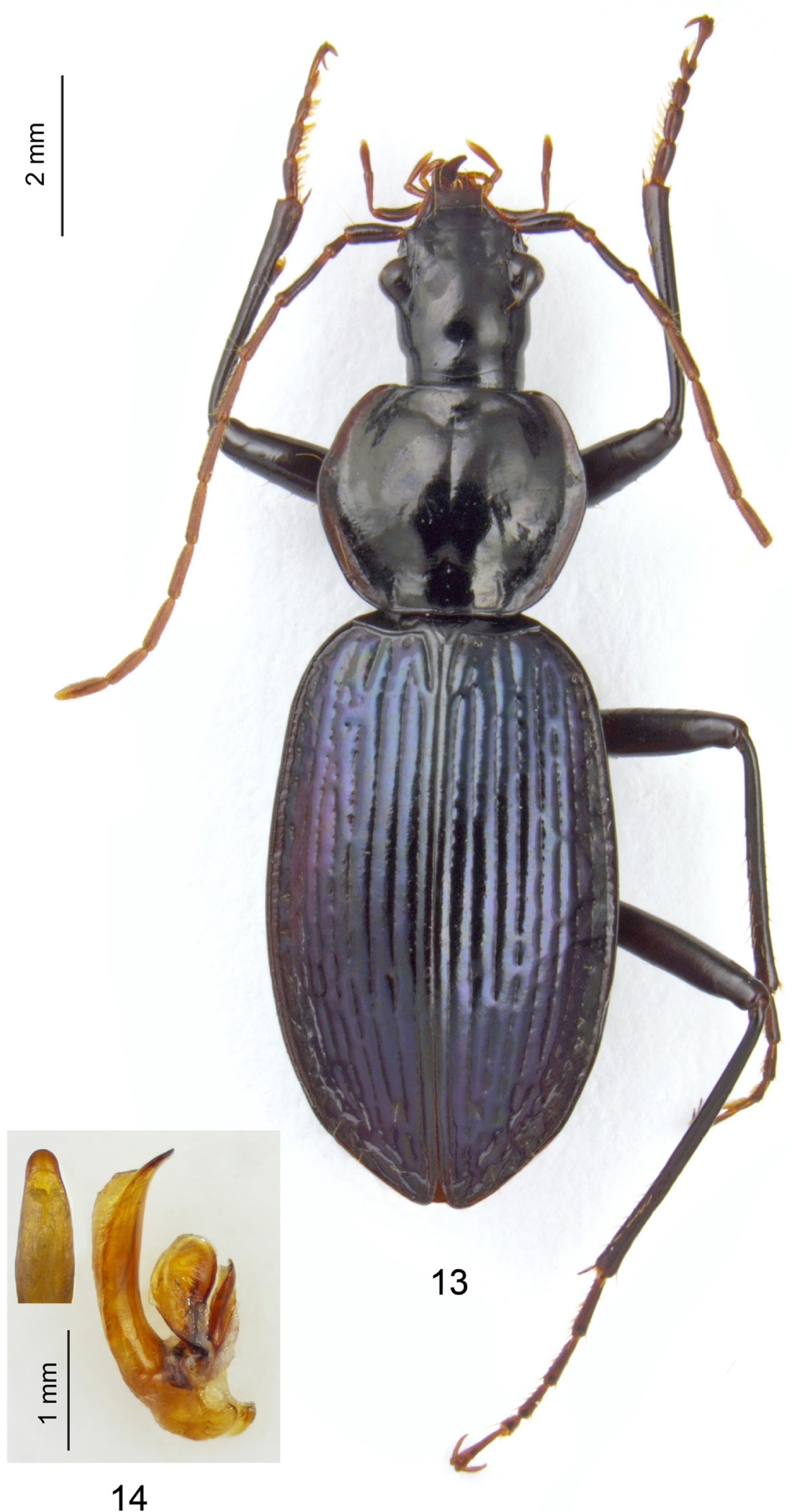

Figs 13-14. Dyscolus globoculus Moret sp. nov. 13. Habitus of the male holotype (MNHN, COI voucher CR064). 14. Aedeagus, median lobe in lateral view. 


\title{
Comparisons
}

Given the unique combination of the following five characters: elytra with violaceous metallic lustre, cylindrical head with hemispherical eyes, rounded pronotum, bisetose third interval of the elytra and setose onychia, Dyscolus globoculus Moret sp. nov. has no close relatives among Neotropical Platynini. Dyscolus globoculus Moret sp. nov. superficially resembles Javanese members of the genus Colpodes in its strongly protruded eyes and explanate margins of the pronotum (Liebherr 1998: fig. 2), but it lacks several derived characters of Colpodes: head with deep sulci bordering the eyes; effaced neck constriction; elytra with a denticle at the sutural apex; fourth tarsomeres without any subapical dorsolateral seta (Moret 1989: fig. 5; Liebherr 1998: figs 4-6). The protuberant eye is probably a homoplastic character which developed independently in these two lineages.

\section{Habitat}

Upper montane forest on the Eastern slope of the Andes, at around $2500 \mathrm{~m}$ a.s.l.

\section{Geographic distribution}

Only known from the type locality in Southern Ecuador, in the Parque Nacional Podocarpus. Probably microendemic.

\author{
Dyscolus donosoi Moret sp. nov. \\ urn:1sid:zoobank.org:act:F31CFECF-7D04-4800-9559-EA234039B5DD
}

Figs $15-16$

\section{Etymology}

Noun in the genitive case, dedicated to David A. Donoso, assistant professor at the Escuela Politécnica Nacional (Quito), specialist of the ecology of neotropical ants, who took part in the discovery of the holotype of this new species.

\section{Type material}

\section{Holotype}

ECUADOR $-q$ (lacks the right foreleg and the right middle leg); Zamora-Chinchipe Province, Parque Nacional Podocarpus, Estación El Colibrí; 359'16.1" S, 795'39.0" W; 2110 m a.s.1.; 18 Mar. 2015; P. Moret, C. Ruiz and D. Donoso leg.; COI voucher PM402-02, BOLD sequence SUM187-18; QCAZ.

\section{Paratypes $(2 \circlearrowleft \widehat{\partial})$}

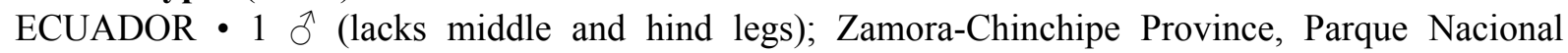
Podocarpus, Fundación Arcoiris; $3.988^{\circ}$ S, $79.093^{\circ}$ W; 2140 m a.s.l.; C. Ruiz and D. Marín leg.; COI voucher CR017, BOLD sequence GBNP014-17; CISEC • 1 त (lacks middle and hind legs); same collection data as for preceding; COI voucher CR018, BOLD sequence GBNP015-17; CISEC.

\section{Diagnostic description}

Habitus: Fig. 15. Wingless. Body length: 11.8-13.9 mm. Body shiny black with a bluish, faintly iridescent lustre on the elytra; femora and tibiae nigropiceous, tarsi and palpi reddish brown; antennomeres 1-3 brunneopiceous, 4-11 reddish brown. Elytral microsculpture transverse. Head elongate, moderately convex, eyes relatively small, not protruding, genae slightly convex; mandibles very long, acute and arcuate at apex. Pronotum large, oval, completely rounded basally, with only one pair of lateral setae, lacking the basal pair; laterobasal depressions shallow. Elytra elongate-oval, convex; base arcuate; striae entire, broad and deeply impressed; intervals flat on disc, subconvex near apex; preapical sinuation obsolete. Third

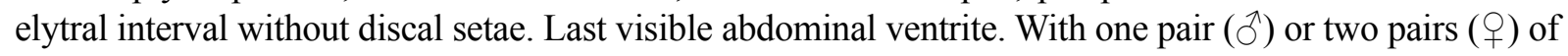



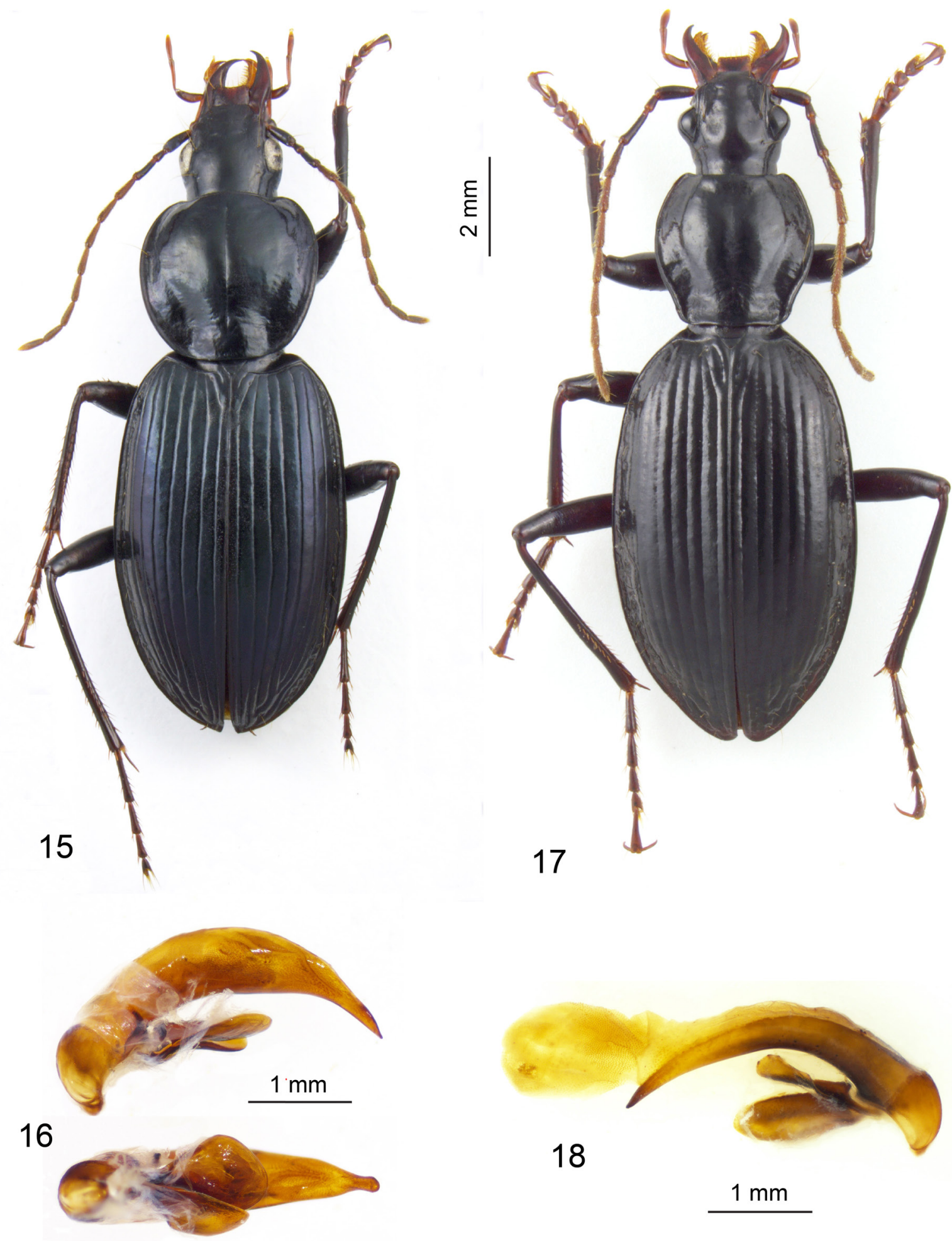

$1 \mathrm{~mm}$

Figs 15-18. 15-16. Dyscolus donosoi Moret sp. nov. 15. Habitus of the female holotype (QCAZ, COI voucher PM402-02). 16. Aedeagus, median lobe in lateral and ventral view. 17-18. D. danglesi Moret sp. nov. 17. Habitus of the male holotype (MNHN, COI voucher PM170-01). 18. Aedeagus, median lobe in lateral view. 
setae along its apical margin. Legs slender, fourth metatarsomere with one pair of subapical dorsolateral setae, apical lobes asymmetrical with a big outer lobe and no inner lobe. Male genitalia: Fig. 16. Median lobe arcuate with a long, spatulate apex, endophallus unarmed. Female genitalia: unstudied.

\section{Comparisons}

Owing to the unique combination of a rounded basal half of pronotum, absence of pronotal hind setae, and asetose third interval of the elytra, Dyscolus donosoi Moret sp. nov. has no close relatives among the described Ecuadorian Dyscolus. In our molecular analysis (Fig. 2) D. donosoi Moret sp. nov. forms a clade with $D$. saxatilis Moret, 1993, but the bootstrap support for this relationship is very weak. Dyscolus saxatilis is a páramo high-altitude species with black non-metallic integuments, broad head, short mandibles, and short and robust appendages.

\section{Habitat}

Montane forest on the Eastern slope of the Andes, at around 2100-2200 m a.s.l. Active at the beginning of the night (7-8.30 pm), on the trunk of a medium-sized tree, one meter above ground.

\section{Geographic distribution}

Only known from the type locality in Southern Ecuador, in the Parque Nacional Podocarpus. Probably microendemic.

Dyscolus danglesi Moret sp. nov. urn:1sid:zoobank.org:act:4D9BB587-2E50-4A2F-BD6A-8C693E0C7029

Figs $17-18$

\section{Etymology}

Noun in the genitive case, dedicated to Olivier Dangles, senior researcher in ecology, companion of Humboldtian adventures.

\section{Type material}

Holotype (only known specimen)

ECUADOR - ${ }^{\top}$; Loja Province, Parque Nacional Yacuri, Waypoint 170; $4.781387^{\circ} \mathrm{S}, 79.386938^{\circ} \mathrm{W}$; 2870 m a.s.1.; 4 Aug. 2016; P. Moret and S. Aguirre leg.; COI voucher PM170-01, BOLD sequence SUM190-18; MNHN.

\section{Diagnostic description}

Habitus: Fig. 17. Wingless. Body length: $12.8 \mathrm{~mm}$. Body entirely black; femora and tibiae nigropiceous, tarsi and palpi reddish brown; antennomeres 1-4 nigropiceous with the base and the apex testaceous, antennomeres 5-11 reddish brown. Elytral microsculpture transverse. Head small, distinctly constricted basally; frons with two broad round depressions close to the anterior supraorbital seta; eyes convex and prominent, genae long, slightly convex; mandibles long, acutely ended. Pronotum cordiform, slightly broader than long; sides feebly arcuate apically, sinuate basally; hind angles rounded; two pairs of lateral setae. Elytra elongate-oval, base very narrow, humeri completely effaced; striae weakly impressed, subpunctate, intervals slightly convex near apex; subapical sinuation obsolete. Third elytral interval without discal setae. Last visible abdominal ventrite of the male with three pairs of setae along its apical margin. Legs slender, fourth metatarsomere with one pair of subapical dorsolateral setae, apical lobes asymmetrical with a big outer lobe and no inner lobe. Male genitalia: Fig. 18. Median lobe arcuate in its basal half, then straight (in lateral view), apex short and blunt, endophallus with seven denticles in a small, slightly sclerotized subapical structure. Female genitalia: unknown. 


\section{Comparisons}

This species shares with D. caulatus Moret, 1993 the general form of the body and the absence of setae on the third interval of the elytra, but $D$. caulatus lacks the anterior supraorbital seta and the posterior pronotal seta, and has a conspicuous foveate elytral pattern.

\section{Habitat}

Upper montane forest on the Eastern slope of the Andes, at around $2870 \mathrm{~m}$ a.s.l. Collected by pyrethrin insecticide fogging on mossy branches and epiphytes, two meters above ground.

\section{Geographic distribution}

Only known from the type locality in Southern Ecuador, in Parque Nacional Yacuri. Probably microendemic.

\section{Dyscolus marini Moret sp. nov. urn:1sid:zoobank.org:act:3E0B11ED-E5E4-438D-9E7B-F7FEC399804B}

Figs 21, 24

\section{Etymology}

Noun in the genitive case, dedicated to Diego Marín, curator of the insect collection (CISEC) at the Universidad Técnica Particular de Loja, Ecuador.

\section{Type material}

\section{Holotype}

ECUADOR - ${ }^{\top}$; Loja Province, Parque Nacional Podocarpus, Cajanuma, Waypoint 392; 4 $6^{\prime} 58.4^{\prime \prime}$ S, 79¹0'18.6" W; $2850 \mathrm{~m}$ a.s.1.; 17 Mar. 2015; P. Moret and C. Ruiz leg.; 19.30-21 pm; bromeliad on tree; COI voucher PM392-10, BOLD sequence SUM057-18; QCAZ.

\section{Paratypes $(5 \hat{\partial} \widehat{\partial}, 3$ 우 $)$}

ECUADOR - Loja Province 11 ; same collection data as for holotype; MNHN 1 o ; Parque Nacional Podocarpus, Cajanuma, Waypoint 397; 4²'2.4" S, 79¹0'6.3" W; 2970 m a.s.1.; 17 Mar. 2015; P. Moret and C. Ruiz leg.; COI voucher PM397-01, BOLD sequence SUM248-18; CPM • 1 +; same collection data as for preceding; QCAZ 252423 • 1 त; Parque Nacional Podocarpus, Cajanuma, Waypoint 399; 47'3.4" S, 799'51.0" W; 3020 m a.s.1.; 17 Mar. 2015; P. Moret and C. Ruiz leg.; COI voucher PM39902, BOLD sequence SUM189-18; CPM - 1 क; Parque Nacional Podocarpus, Cajanuma; 4.115 S, 79.171 W; 2870 m a.s.1.; 4 Jul. 2013; D. Marín and C. Ruiz leg.; COI voucher CR029, BOLD sequence GBNP020-17; CISEC • 1 §ं; Parque Nacional Podocarpus, Cajanuma; $4^{\circ} 5^{\prime} 5$ S, $79^{\circ} 12^{\prime}$ W; 2750 m a.s.l.; 28-30 Dec. 2001; G. Beltrán leg.; QCAZ 74257.

\section{Diagnostic description}

Habitus: Fig. 21. Wingless. Body length: 9.9-12.3 mm. Body colour variable, from reddish brown to brunneous; legs, antennae and mouthparts reddish brown. Elytral microsculpture isodiametric. Head elongate, markedly constricted basally, eyes prominent, genae flat. Pronotum subcordiform; sides arcuate anterad, sinuate posterad before the hind angles which are slightly obtuse or right angled; two pairs of lateral setae. Elytra depressed medially; striae entire, well impressed, relatively broad; intervals flat. Third elytral interval with two or three setae (when only two setae, the median one is missing). Last visible abdominal ventrite with one pair $\left({ }^{\top}\right)$ or two pairs $(+)$ of setae along its apical margin. Legs: tarsi rugose dorsally, metatarsomeres 1-3 bisulcate, fourth metatarsomere with one pair of dorsolateral subapical setae, apical lobes moderately long, the external lobe 1.5 times longer than the inner lobe; fifth 
metatarsomere asetose ventrally. Male genitalia: Fig. 24. Median lobe arcuate, apex short, endophallus without sclerotized structure. Female genitalia: unstudied.

\section{Comparisons}

According to the currently available molecular data, Dyscolus marini Moret sp. nov. belongs to the same clade as D. ruizi Moret sp. nov., D. arborarius Moret sp. nov., D. moretianus Perrault, 1993, D. sulcipedis Moret sp. nov. and D. rugitarsis Moret sp. nov. However, by its external characters it has a close resemblance to D. ravidus Moret sp. nov., which belongs to a different clade. Dyscolus marini Moret sp. nov. differs from $D$. ravidus Moret sp. nov. by the following characters: elytra with the same colour as the pronotum; eyes more convex; hind angles of the pronotum obtuse; elytral striae wider; third interval with at least two discal setae; elytral microsculpture isodiametric; male genitalia: apical blade of the median lobe two times shorter than in D. ravidus Moret sp. nov.

\section{Habitat}

Upper montane forest on the Eastern slope of the Andes, 2750-3050 m a.s.l., found at the beginning of the night on the surface of the leaf litter and above ground on mossy trunks or on epiphytes, especially in leaf axils of epiphytic bromeliads.

\section{Geographic distribution}

Only known from the type locality in Southern Ecuador. Probably microendemic.

Dyscolus rugitarsis Moret sp. nov. urn:1sid:zoobank.org:act:924335EA-EF3D-4630-8607-DE9A9749EEFA

Figs 19, 22

\section{Etymology}

Compound Latin adjective meaning 'with rugose tarsi'.

\section{Type material}

\section{Holotype}

ECUADOR - ${ }^{\text {; }}$; Loja Province, Parque Nacional Yacuri, Waypoint $167 ; 4.711861^{\circ} \mathrm{S}, 79.440355^{\circ} \mathrm{W}$; 3240 m a.s.l.; 4 Aug. 2016; P. Moret, S. Aguirre and E. Moreno leg.; QCAZ.

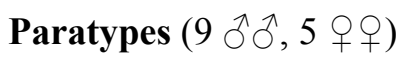

ECUADOR - Loja Province $\bullet 1$; same collection data as for holotype; CPM $\bullet 1$ ô; same collection data as for holotype; COI voucher PM167-05, BOLD sequence SUM060-18; CPM ・ 4 ふぇぇ, 3 우우; Cordillera Lagunillas, Waypoint 3; $4.71198^{\circ}$ S, 79.44045 $\mathrm{W}$; $3240 \mathrm{~m}$ a.s.1.; 11 Aug. 2013; P. Moret leg.; CPM • 1 ; ; same collection data as for preceding; MNHN • $2 \hat{\jmath} \widehat{\jmath}, 1$; ; same collection data as for preceding; QCAZ • 1 §ं; Cordillera Lagunillas, Vía Jimbura-Zumba; 3200 m a.s.1.; 15 Jul. 2001; P. Moret leg.; CPM.

\section{Diagnostic description}

Habitus: Fig. 19. Wingless. Body length: 10.1-11.0 mm. Body colour variable, from brunneous to brownish black; femora brownish; rest of the legs, antennae and mouthparts reddish brown. Elytral microsculpture variable, mostly isodiametric in the middle part of the intervals, oblong near the striae. Head broad, weakly constricted basally, eyes moderately bulging, genae flat. Pronotum transverse, sides slightly arcuate anterad, weakly sinuate posterad; hind angles obtuse; two pairs of lateral setae. Elytra ovoid, slightly convex; striae entire, well impressed, relatively broad; intervals variable, flat to slightly 

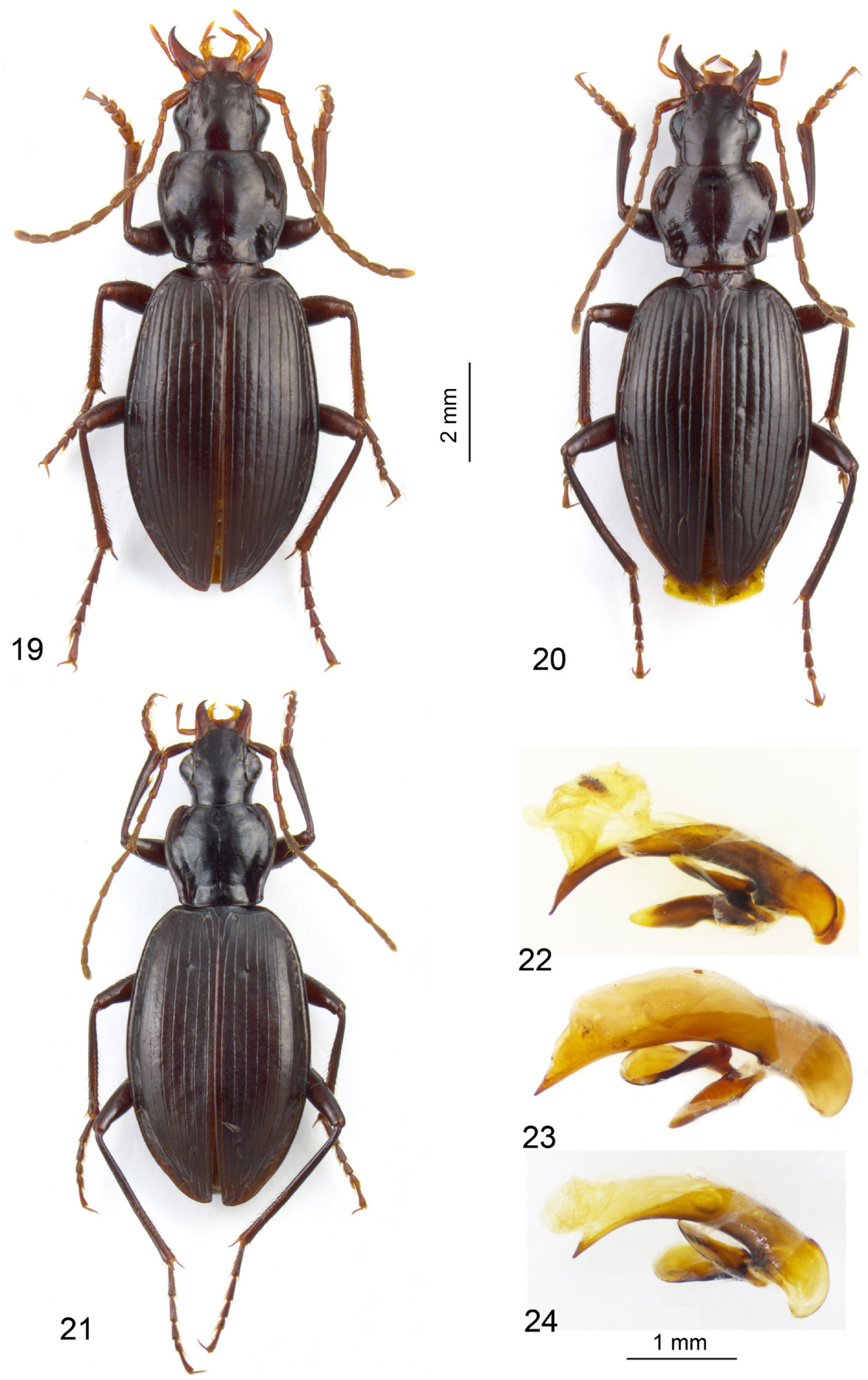

Figs 19-24. Dyscolus spp., habitus (19-21) and aedeagus, median lobe in lateral view (22-24). 19. D. rugitarsis Moret sp. nov., male holotype (QACZ). 20. D. sulcipedis Moret sp. nov., male holotype (QACZ). 21. D. marini Moret sp. nov., female paratype. 22. D. rugitarsis Moret sp. nov. 23. D. sulcipedis Moret sp. nov. 24. D. marini Moret sp. nov. 
convex. Third elytral interval with 2-3 setae (two specimens lack the anterior seta on one elytron only). Last visible abdominal ventrite with one pair $\left({ }^{\Uparrow}\right)$ or two pairs $(+$ ) ) of setae along its apical margin. Legs: tarsi rugose dorsally, metatarsomeres 1-4 bisulcate, fourth metatarsomere with one pair of dorsolateral subapical setae, apical lobes moderately long, the external lobe two times longer than the inner lobe; fifth metatarsomere broadened and dorsally depressed in basal half, ventrally asetose. Male genitalia: Fig. 22. Median lobe arcuate, apex relatively large, very thin in lateral view, endophallus with one subapical sclerotized structure. Female genitalia: unstudied.

\section{Comparisons}

Dyscolus rugitarsis Moret sp. nov. is closely related, within the D. marini Moret sp. nov. clade, to D. moretianus which inhabits the western part of the Loja Province in the Parque Podocarpus, $70 \mathrm{~km}$ northwest from the type locality of this new species. Dyscolus rugitarsis Moret sp. nov. differs from the latter by the blunter hind angles of the pronotum, the presence of at least one seta in the basal half of the third elytral interval (third interval asetose in D. moretianus), slightly longer antennae and tarsi, and a markedly longer external lobe at the apex of the fourth metatarsomere. For comparison with D. sulcipedis Moret sp. nov., see below (p. 27).

\section{Habitat}

Upper montane forest, at around 3200-3250 $\mathrm{m}$ a.s.1. Active at the beginning of the night on the surface of the leaf litter.

\section{Geographic distribution}

Only known from the type locality in Southern Ecuador, in Parque Nacional Yacuri. Probably microendemic.

Dyscolus sulcipedis Moret sp. nov. urn:1sid:zoobank.org:act:611661EF-D8A2-4E28-8622-349EC9F6C992

Figs 20, 23

\section{Etymology}

Compound Latin adjective meaning 'with sulcate feet' (i.e., tarsi).

\section{Type material}

\section{Holotype}

ECUADOR - ${ }^{\top}$; Loja Province, Parque Nacional Yacuri, Waypoint $167 ; 4.711861^{\circ} \mathrm{S}, 79.440355^{\circ} \mathrm{W}$; 3240 m a.s.l.; 4 Aug. 2016; P. Moret, S. Aguirre and E. Moreno leg.; QCAZ.

Paratypes $(2 \lesssim \Uparrow, 2$ 우 $)$

ECUADOR • 1 \%; same collection data as for holotype; MNHN $\bullet 2$ + $q$; same collection data as for holotype; CPM • 1 § ; same collection data as for holotype; COI voucher PM167-09, BOLD sequence SUM061-18; CPM.

\section{Diagnostic description}

Habitus: Fig. 20. Wingless. Body length: 10.6-11.5 mm. Body colour variable, from brunneous to brownish black; femora and tibiae brownish; tarsi, antennae and mouthparts reddish brown. Elytral microsculpture transverse, weakly impressed. Head moderately broad, constricted basally, eyes moderately bulging, genae flat. Pronotum subcordiform, transverse, sides arcuate anterad, markedly sinuate posterad; hind angles slightly obtuse or almost right angled; two pairs of lateral setae. Elytra elongate-ovoid, slightly 
convex; striae entire, well impressed; intervals variable, flat to slightly convex in basal half, convex at apex. Third elytral interval with three setae. Last visible abdominal ventrite with two pairs $\left(\delta^{\Uparrow}\right)$ or four pairs ( $(+)$ of setae along its apical margin. Legs: tarsi smooth dorsally, metatarsomeres 1-3 bisulcate, fourth metatarsomere with one pair of dorsolateral subapical setae, apical lobes moderately long, the external lobe 1.5 times longer than the inner lobe; fifth metatarsomere convex dorsally, asetose ventrally. Male genitalia: Fig. 23. Median lobe weakly arcuate, apex short, acute, endophallus without sclerotized structure. Female genitalia: unstudied.

\section{Comparisons}

Dyscolus sulcipedis Moret sp. nov. belongs to the marini clade along with D. marini Moret sp. nov., D. ruizi Moret sp. nov., D. arborarius Moret sp. nov., D. moretianus and D. rugitarsis Moret sp. nov. Based on external morphology (not on molecular data), its closest relative is D. rugitarsis Moret sp. nov., from which it differs mainly in the following characters: elytral microsculpture transverse, weakly impressed (coarser and mostly isodiametric in D. rugitarsis Moret sp. nov.); head slightly narrower; latero-posterior sinuation of the pronotum deeper; last visible abdominal ventrite with two pairs $\left({ }^{\Uparrow}\right)$ or four pairs ( + ) of apical setae (one and two pairs in D. rugitarsis Moret sp. nov.); tarsi not rugose; fifth metatarsomere plesiomorphic, not broadened and dorsally depressed.

\section{Habitat}

Upper montane forest, at around $3240 \mathrm{~m}$ a.s.l. Active at the beginning of the night on the surface of the leaf litter and on tree trunks $2 \mathrm{~m}$ above ground.

\section{Geographic distribution}

Only known from the type locality in Southern Ecuador, in Parque Nacional Yacuri. Probably microendemic.

$$
\begin{aligned}
& \text { Dyscolus arborarius Moret sp. nov. } \\
& \text { urn:1sid:zoobank.org:act:6FD45E2B-C31E-4486-8285-F537FCBF4FB6 }
\end{aligned}
$$

Figs $25-26$

\section{Etymology}

Latin adjective meaning 'related to trees'.

\section{Type material}

Holotype (only known specimen)

ECUADOR - \} \text { ; Loja Province, Parque Nacional Yacuri, Waypoint 170; } 4 . 7 8 1 3 8 7 ^ { \circ } \mathrm { S } , 7 9 . 3 8 6 9 3 8 ^ { \circ } \mathrm { W } \text { ; } 2870 m a.s.1.; 4 Aug. 2016; P. Moret and S. Aguirre leg.; COI voucher PM170-02, BOLD sequence SUM191-18; MNHN.

\section{Diagnostic description}

Habitus: Fig. 25. Wingless. Body length: $10.8 \mathrm{~mm}$. Body dark brown with the sides of the pronotum and the elytral sutura reddish brown; femora dark brown; rest of the legs, antennae and mouthparts reddish brown. Elytral microsculpture shallowly impressed, transverse. Head large and convex; eyes prominent, very convex; basal constriction strong; mandibles relatively short. Antennae thin, very elongate. Pronotum subcordiform, sides moderately arcuate anterad, slightly sinuate posterad; hind angles obtuse; two pairs of lateral setae. Elytra elongate-ovate with effaced humeri, subapical sinuation obsolete; striae narrow and shallowly impressed; intervals flat; third elytral interval with two or three discal setae. Last visible abdominal ventrite of the male with two pairs of apical setae. Legs thin and 

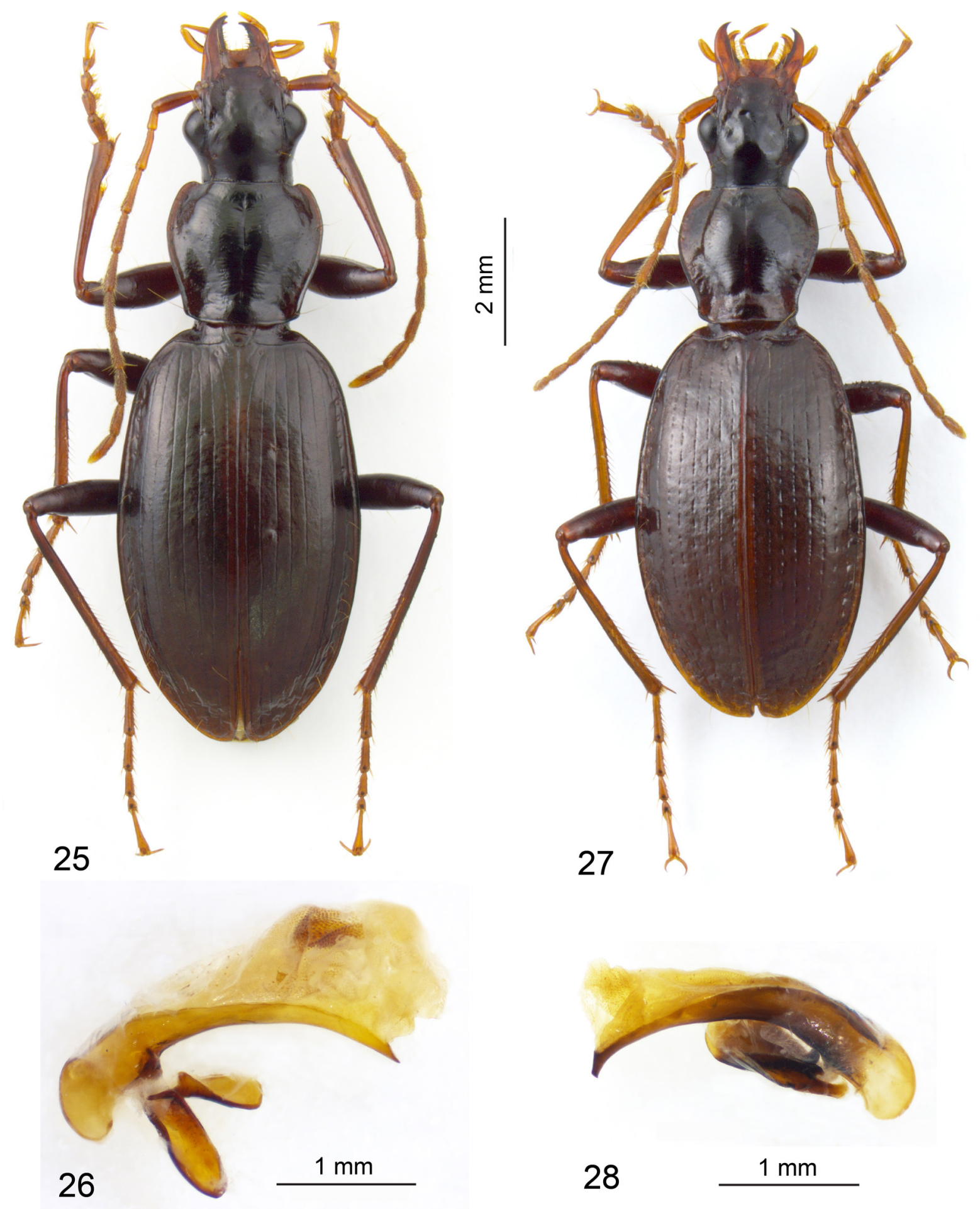

Figs 25-28. 25-26. Dyscolus arborarius Moret sp. nov. 25. Habitus of the male holotype (MNHN, COI voucher PM170-02). 26. Aedeagus, median lobe in lateral view. 27-28. D. famelicus Moret sp. nov. 27. Habitus of a female paratype (CPM). 28. Aedeagus, median lobe in lateral view. 
elongate. Fourth metatarsomere oval-shaped, with one pair of dorsolateral subapical setae and long apical lobes, the external lobe nearly two times longer than the inner lobe. Male genitalia: Fig. 26. Median lobe weakly arcuate, apex short, acute, endophallus with one subapical sclerotized structure. Female genitalia: unknown.

\section{Comparisons}

According to the COI gene, D. arborarius Moret sp. nov. belongs to the marini clade, close to D. ruizi Moret sp. nov. It can be easily distinguished from the other species of this clade by its slender body, large head with very prominent eyes, and effaced humeri.

\section{Habitat}

Upper montane forest on the Eastern slope of the Andes, at around $2870 \mathrm{~m}$ a.s.l. Collected by pyrethrin insecticide fogging on mossy branches and epiphytes, two metres above ground.

\section{Geographic distribution}

Only known from the type locality in Southern Ecuador, in Parque Nacional Yacuri. Probably microendemic.

Dyscolus famelicus Moret sp. nov. urn:1sid:zoobank.org:act:FC15AE30-F921-48BF-BFDE-DD80F0CF7351

Figs $27-28$

\section{Etymology}

Latin adjective meaning 'scrawny, gaunt', in allusion to the narrow and slender body of this species.

\section{Type material}

\section{Holotype}

ECUADOR - Ō; Napo Province, East of Papallacta-Guango Lodge, Waypoint 40; 0²2'42.6" S, 78²'26.6" W; 2708 m a.s.1.; 24 Oct. 2015; P. Moret leg.; QCAZ.

Paratypes ( $2 \widehat{\diamond}, 2$ 우)

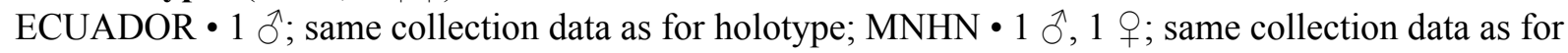
holotype; CPM • 1 ; ; same collection data as for holotype; COI voucher PM040-02, BOLD sequence SUM184-18; CPM.

\section{Diagnostic description}

Habitus: Fig. 27. Wingless. Body length: 9.6-10.5 mm. Elytra brownish, disc of the pronotum brownish black, margins of the pronotum brownish as the elytra, head piceous black; femora brownish, tibiae, tarsi, mouthparts and antennae reddish brown. Elytral microsculpture isodiametric. Head narrow with bulging eyes, frons with two foveae. Pronotum elongate, as wide as long, constricted basally; lateroapical lobes reduced; hind angles laterally prominent, broadly rounded; two pairs of lateral setae. Elytra elongate, ovoid, with effaced humeri and no hint of subapical sinuation; striae shallow, broken into dashes over elytral disc; intervals flat; third interval without discal setae. Last visible abdominal

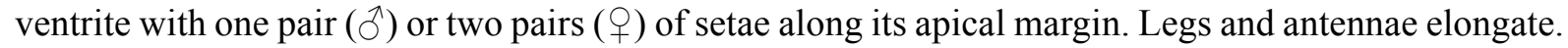
Male genitalia: Fig. 28. Median lobe forming an obtuse angle after basal third (in lateral view), apex short, denticulate and bent downward in lateral view; endophallus without sclerotized structure. Female genitalia: unstudied. 


\section{Comparisons}

The slender, elongate body form, the dashed elytral setae and the hooked apex of the aedeagus separate D. famelicus Moret sp. nov. from any other species having an asetose third elytral interval. Our molecular analysis (Fig. 2) places this species close to D. gobbii Moret sp. nov. which lives in the páramo and has a very different external morphology, but the bootstrap support for this relationship is weak.

\section{Habitat}

Upper montane forest on the Eastern slope of the Andes, at around $2700 \mathrm{~m}$ a.s.1., collected above ground at the beginning of the night, on mossy trunks and on epiphytes.

\section{Geographic distribution}

Only known from the type locality in Northern Ecuador, probably microendemic.

Dyscolus crespoae Moret sp. nov. urn:1sid:zoobank.org:act:AEA12495-C2BD-4A65-AACF-C54DB6CAFBA7

Fig. 29

\section{Etymology}

Noun in the genitive case, dedicated to Verónica Crespo, professor at the Pontificia Universidad Católica del Ecuador, limnologist and specialist of the ecology of Andean tropical streams.

\section{Type material}

\section{Holotype}

ECUADOR - + ; Zamora-Chinchipe Province, Parque Nacional Podocarpus, Estación El Colibrí; $3^{\circ} 59^{\prime} 16.1^{\prime \prime}$ S, 795'39.0" W; 2110 m a.s.1.; 18 Mar. 2015; P. Moret and C. Ruiz leg.; by night 19.30$21 \mathrm{pm}$; on the ground; QCAZ.

\section{Paratype}

ECUADOR • 1 क; same collection data as for holotype; COI voucher PM402-03, BOLD sequence SUM188-18; CPM.

\section{Diagnostic description}

Habitus: Fig. 29. Wingless. Body length: $10.6 \mathrm{~mm}$ (paratype) to $11.3 \mathrm{~mm}$ (holotype). Head and pronotum black, elytra nigropiceous; legs, antennae and mouthparts brownish to reddish brown. Dorsal integuments shiny, elytral microsculpture transverse. Head relatively small, elongate, eyes prominent, genae long, almost flat. Pronotum cordiform; sides markedly sinuate basally, hind angles obtuse and sharp; laterobasal impressions deep, lateral margins reflexed; two pairs of lateral setae. Elytra oval, convex; striae entire, shallowly impressed, distinctly punctate; intervals flat; preapical sinuation weakly marked. Third elytral interval without discal setae. Last visible abdominal ventrite with two pairs of setae along its apical margin. Legs moderately slender, all tarsi densely pubescent ventrally; metatarsomeres 1-3 bisulcate; external lobe of the fourth metatarsomere 2.5 times longer than inner lobe; fifth metatarsomere asetose ventrally. Male unknown. Female genitalia: unstudied.

\section{Comparisons}

This species belongs to the same clade as D. ravidus Moret sp. nov. Both have the same general aspect and share the character of an asetose third interval, but in D. crespoae Moret sp. nov. the dorsal surface is shiny with a transverse microsculpture on the elytra, the elytra are more convex, the hind angles of 

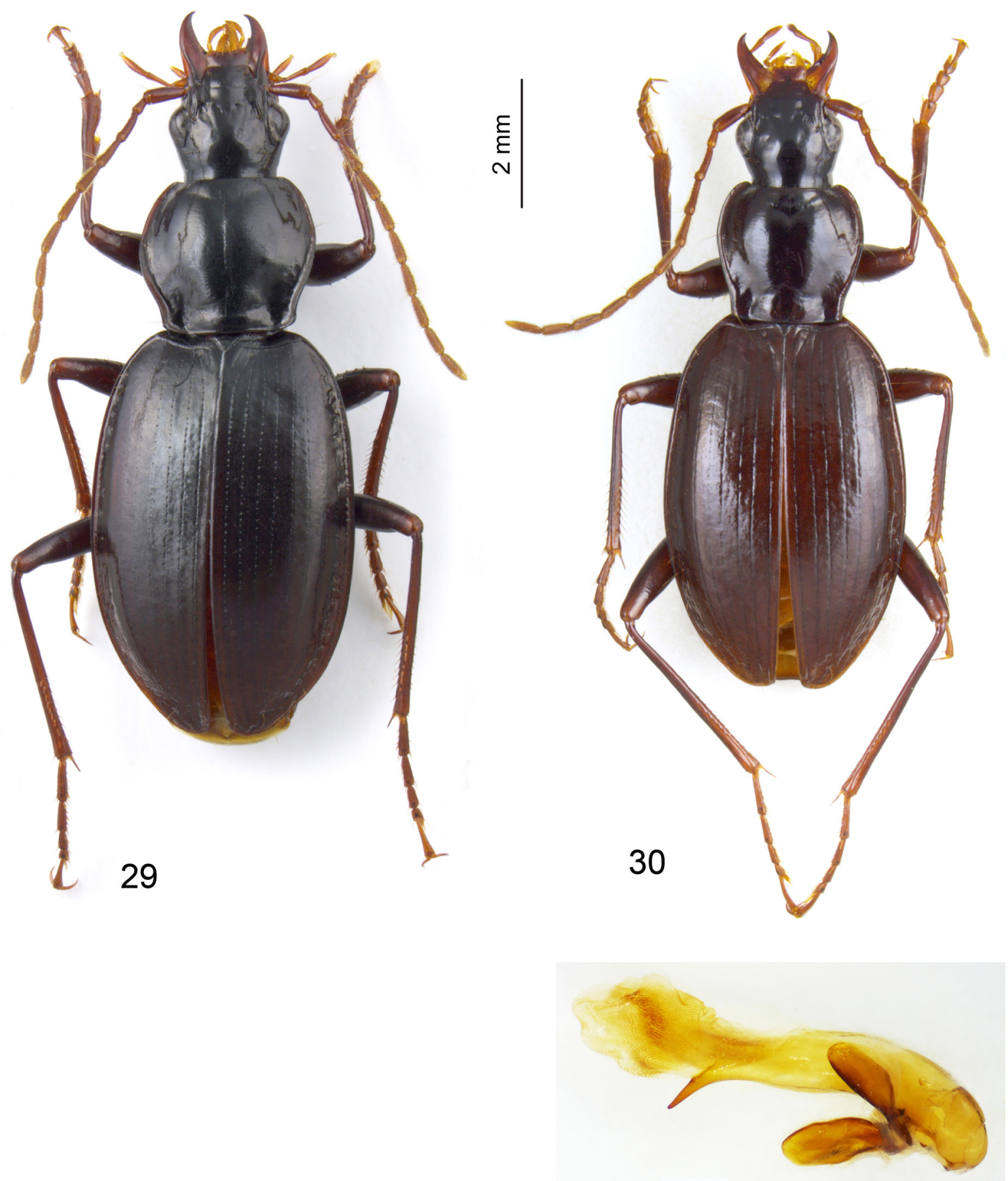

31

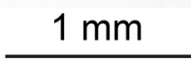

Figs 29-31. 29. Dyscolus crespoae Moret sp. nov., habitus of the female holotype (QACZ). 3031. D. ravidus Moret sp. nov. 30. Habitus of the male holotype (QACZ). 31. Aedeagus, median lobe in lateral view. 
the pronotum more obtuse, the ventral pubescence of the tarsi denser, the apical lobes of the fourth metatarsomere more asymmetrical.

\title{
Habitat
}

Montane forest on the Eastern slope of the Andes, at around $2100 \mathrm{~m}$ a.s.l. Active at the beginning of the night $(7.30-9 \mathrm{pm})$ on the surface of the leaf litter above ground.

\section{Geographic distribution}

Only known from the type locality in Southern Ecuador, in the Parque Nacional Podocarpus. Probably microendemic.

\author{
Dyscolus ravidus Moret sp. nov. \\ urn:1sid:zoobank.org:act:8449EDAE-130C-468E-A1F3-78EE6FB86649
}

Figs $30-31$

\section{Etymology}

Latin adjective meaning 'dark' .

\section{Type material}

Holotype

ECUADOR - Ô; Loja Province, Cajanuma, Refugio Parque Nacional Podocarpus; $4^{\circ} 6^{\prime} 58.4^{\prime \prime}$ S, 79¹0'18.6" W; 2850 m a.s.1.; 17 Mar. 2015; P. Moret and C. Ruiz leg.; QCAZ.

Paratypes $(7 \hat{\jmath}, 5$ 우 $)$

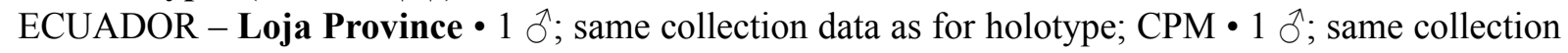
data as for holotype; QCAZ $\bullet 1$ ก, 1 \%; Cajanuma, Refugio Parque Nacional Podocarpus, Waypoint 166; 4.11617 $\mathrm{S}, 79.17204^{\circ} \mathrm{W} ; 2840 \mathrm{~m} ; 2$ Aug. 2016; P. Moret leg.; CPM • 1 Oे, 1 q; same collection data as for preceding; MNHN • 1 đ̊; Valladolid, Límite del Parque Jocotoco y Podocarpus; 6 Jan. 2001; I.G. Tapia leg.; QCAZ • 1 q; Parque Nacional Podocarpus; 2800 m a.s.1.; 12 Feb. 1994; G. Onore leg.; QCAZ・ 1 क; Mamanuma; 2700 m a.s.1.; 28 Dec. 1994; G. Onore leg.; CISEC • 1 ठ̊; Parque Nacional Podocarpus, Cajanuma, Waypoint 397; 4²'2.4" S, 79¹0'6.3" S; 2970 m a.s.1.; 17 Mar. 2015; P. Moret and C. Ruiz leg.; COI voucher PM397-02, BOLD sequence SUM058-18; CPM • 1 ô; same collection data as for preceding; COI voucher PM397-03, BOLD sequence SUM249-18; CPM • 1 \&; km 10 vía Saraguro-Loja; 2850 m a.s.1.; 21 Jul. 1988; P. Moret leg.; CPM.

\section{Diagnostic description}

Habitus: Fig. 30. Wingless. Body length: 9.5-10.8 mm. Body colour from reddish brown to brunneous; legs, antennae and mouthparts reddish brown. Elytral microsculpture transverse. Head elongate, markedly constricted basally, eyes moderately convex, genae flat. Pronotum subcordiform; sides arcuate anterad, sinuate posterad before the hind angles which are sharp and right angled. Elytra slightly convex; striae entire but narrow and shallowly impressed, intervals flat; third interval without discal setae. Last visible abdominal ventrite with one pair $(\widehat{\delta})$ or two pairs $(+$ ) of setae along its apical margin. Legs: tarsi smooth dorsally, metatarsomeres 1-3 bisulcate, fourth metatarsomere with one pair of dorsolateral subapical setae, apical lobes moderately long, the external lobe $>2$ times longer than the inner lobe; fifth metatarsomere asetose ventrally. Male genitalia: Fig. 31. Ventral side of the median lobe bisinuate in lateral view; apical blade elongate; endophallus with a dense squamose area. Female genitalia: unstudied. 


\section{Comparisons}

According to the currently available molecular data, Dyscolus ravidus Moret sp. nov. belongs to the same clade as $D$. crespoae Moret sp. nov. (see above in the description of the latter for the morphological differences between them). However, by its external characters, D. ravidus Moret sp. nov. has a closer resemblance to D. marini Moret sp. nov., which belongs to a different clade. Dyscolus ravidus Moret sp. nov. differs from $D$. marini Moret sp. nov. by the following characters: elytra brownish in contrast with a black or piceous black pronotum; eyes less convex; hind angles of the pronotum sharper, right angled; elytral striae narrower and more shallowly impressed; third interval without discal setae; elytral microsculpture transverse; male genitalia: apical blade of the median lobe two times as long as in D. marini Moret sp. nov.

\section{Habitat}

Upper montane forest on the Eastern slope of the Andes, between 2700 and $2900 \mathrm{~m}$ a.s.l. Active at the beginning of the night (7.30-9 pm) on the ground and in leaf axils of epiphytic bromeliads.

\section{Geographic distribution}

Only known from the Parque Nacional Podocarpus in Southern Ecuador. Probably microendemic.

Dyscolus ruizi Moret sp. nov. urn:lsid:zoobank.org:act:811C080F-1087-49A8-BB75-7B71DA04C593

Figs $34-35$

\section{Etymology}

Noun in the genitive case, dedicated to Carlos Ruiz Carreira, associate professor at the Universidad de La Laguna (Canarias), who investigated in 2013-2014 the biodiversity of carabid beetles along an elevational gradient between Loja and Zamora.

\section{Type material}

\section{Holotype}

ECUADOR - ${ }^{\wedge}$; Loja Province, Parque Nacional Podocarpus, Cajanuma, Waypoint 397; 4 $4^{\circ} 2.4^{\prime \prime}$ S, 79¹0'6.3" W; 2900 m a.s.1.; 17 Mar. 2015; P. Moret and C. Ruiz leg.; COI voucher PM392-68, BOLD sequence SUM056-18; QCAZ.

Paratypes $(10 \AA \hat{\jmath}, 5 q \circ)$

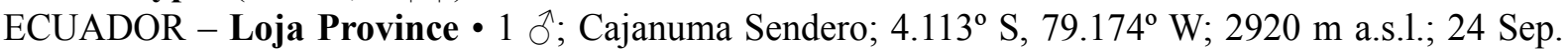
2013; D. Marín and C. Ruiz leg.; CISEC $\bullet 1$; ; same collection data as for preceding; COI voucher CR120, BOLD sequence GBNP068-17; QCAZ • 1 đo; El Tiro; $3.993^{\circ} \mathrm{S}, 79.147^{\circ} \mathrm{W} ; 2838 \mathrm{~m}$ a.s.1.; 11 Jul. 2013; D. Marín and C. Ruiz leg.; COI voucher CR008, BOLD sequence GBNP006-17; CISEC • 1 ô, 1 क; Saraguro, Huashapamba; 2920 m a.s.1.; 10 Dec. 2005; I. Mas leg.; CISEC 0003240, 0003271 - 1 \} \text { ; same collection data as for preceding; CPM. - Loja / Zamora Province • } 1 \text { ô; El Tiro-Cima; }

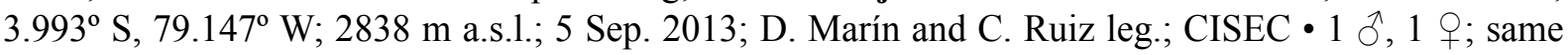

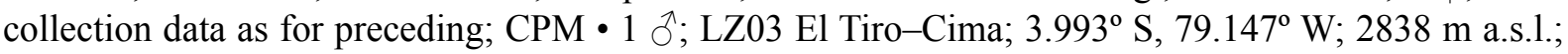
11 Jul. 2013; D. Marín and C. Ruiz leg.; MNHN • 1 क; LZ03 El Tiro; 2813 m a.s.1.; 26 Mar. 2008; Marín Rosero leg.; CISEC 0002573. - Zamora-Chinchipe Province • 1 \%; Carretera Loja-Zamora; 3.988 S, $79.118^{\circ}$ W; 2528 m a.s.1.; 18 Jul. 2013; D. Marín and C. Ruiz leg.; COI voucher CR002, BOLD sequence GBNP002-17; CISEC • 1 q; same collection data as for preceding; COI voucher CR003, BOLD sequence GBNP003-17; CISEC • 1 \%; same collection data as for preceding; 5 Dec. 2013; D. Marín and C. Ruiz leg.; COI voucher CR001, BOLD sequence GBNP001-17; CISEC • 1 §; same collection data as for preceding; COI voucher CR055, BOLD sequence GBNP029-17; CISEC. 


\section{Diagnostic description}

Habitus: Fig. 34. Wingless. Body length: 9.2-11.3 mm. Entirely black or piceous black. Elytral microsculpture finely transverse, weakly impressed. Head broad basally, feebly constricted, eyes small, genae long and convex; antennae short. Pronotum elongate, wider at apex than at base; sides moderately arcuate apically, straight or feebly sinuate basally; hind angles obtuse and blunt; two pairs of lateral setae, the basal one anterad the hind angle. Elytra narrow depressed medially; no subapical sinuation; striae entire, well impressed; intervals flat to subconvex. Third elytral interval with two setae, one near base and one near apex, or with only one subapical seta. Last visible abdominal ventrite with one pair $\left({ }^{\lambda}\right)$ or two pairs (ㅇ) of setae along its apical margin. Legs robust, anterior femora swollen; dorsal surface of tarsi rugose, almost squamose, not sulcate; fourth metatarsomere with one pair of dorsolateral subapical setae, apical lobes short, the external lobe two times longer than the inner lobe; fifth metatarsomere asetose ventrally. Male genitalia: Fig. 35. Median lobe arcuate, apex robust, acute, endophallus without sclerotized structure. Female genitalia: unstudied.

\section{Comparisons}

Dyscolus ruizi Moret sp. nov. belongs to the same clade as D. marini Moret sp. nov., D. arborarius Moret sp. nov., D. moretianus, D. sulcipedis Moret sp. nov. and D. rugitarsis Moret sp. nov. However, by its robust legs, short antennae, small eyes and convex genae, D. ruizi Moret sp. nov. is more similar to species living at higher elevations in the páramo, as D. denigratus (Bates 1891), than to these species which share the same forest environment beneath $3000 \mathrm{~m}$. Dyscolus ruizi Moret sp. nov. differs from D. denigratus by its elongate pronotum and the absence of the middle seta on the third interval.

\section{Habitat}

Upper montane forest and subpáramo on the eastern slope of the Andes, at around 2800-3000 m a.s.1. The specimens from Saraguro-Huashapamba were collected in pitfall traps baited with dung.

\section{Geographic distribution}

Only known from the Parque Nacional Podocarpus and surroundings, in southern Ecuador. Probably microendemic.

$$
\begin{aligned}
& \text { Dyscolus salazarae Moret sp. nov. } \\
& \text { urn:1sid:zoobank.org:act:CD4CC653-FE0C-466A-A380-4C3361CB8579 }
\end{aligned}
$$
Figs $32-33$

\section{Etymology}

Noun in the genitive case, dedicated to Fernanda Salazar, administrator of the invertebrate collection of the QCAZ Museum (Pontificia Universidad Católica del Ecuador, Quito).

\section{Type material}

Holotype (only known specimen)

ECUADOR - $\mathrm{O}^{\lambda}$; Loja Province, Parque Nacional Podocarpus, Cajanuma, Waypoint 392; 4 ${ }^{\circ} 6^{\prime} 58.4^{\prime \prime}$ S, 79¹0'18.6" W; 2850 m a.s.1.; 17 Mar. 2015; P. Moret and C. Ruiz leg.; COI voucher PM392-09, BOLD sequence SUM059-18; MNHN.

\section{Diagnostic description}

Habitus: Fig. 32. Wingless. Body length: 9.3-9.6 mm. Head, pronotum and elytra brunneopiceous; legs, antennae and mouthparts reddish brown. Elytral microsculpture isodiametric. Head convex, markedly constricted basally, eyes small, not bulging, genae almost flat in dorsal view, as long as the eyes. Pronotum 


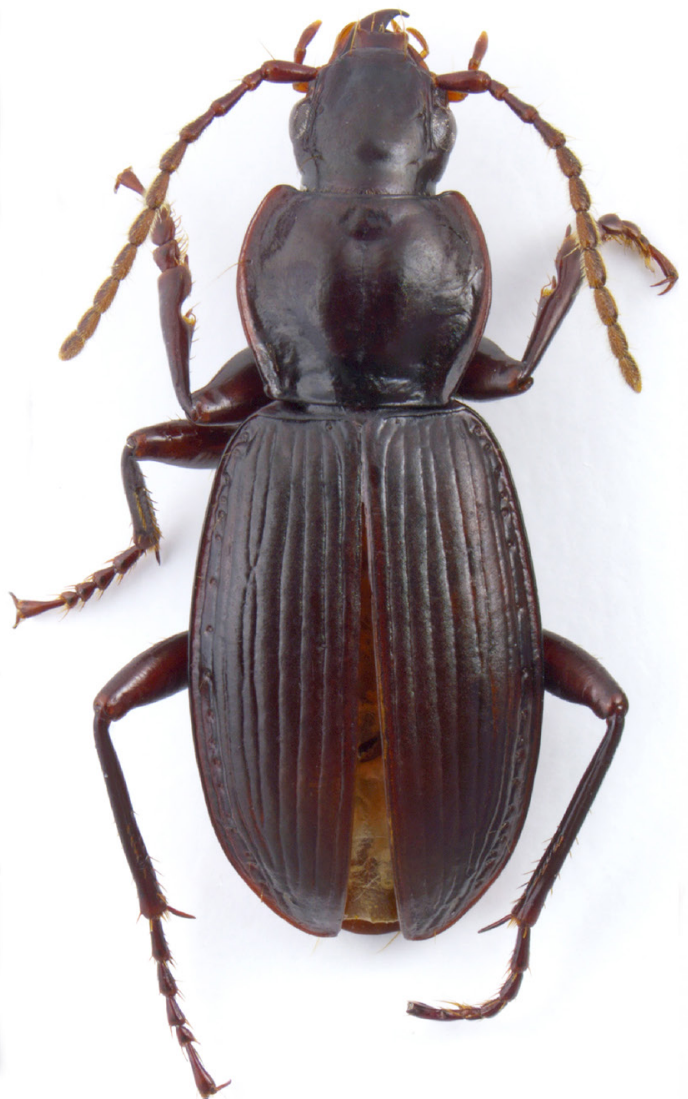

32

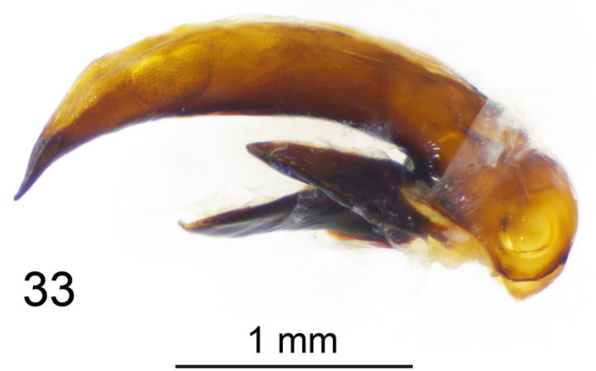

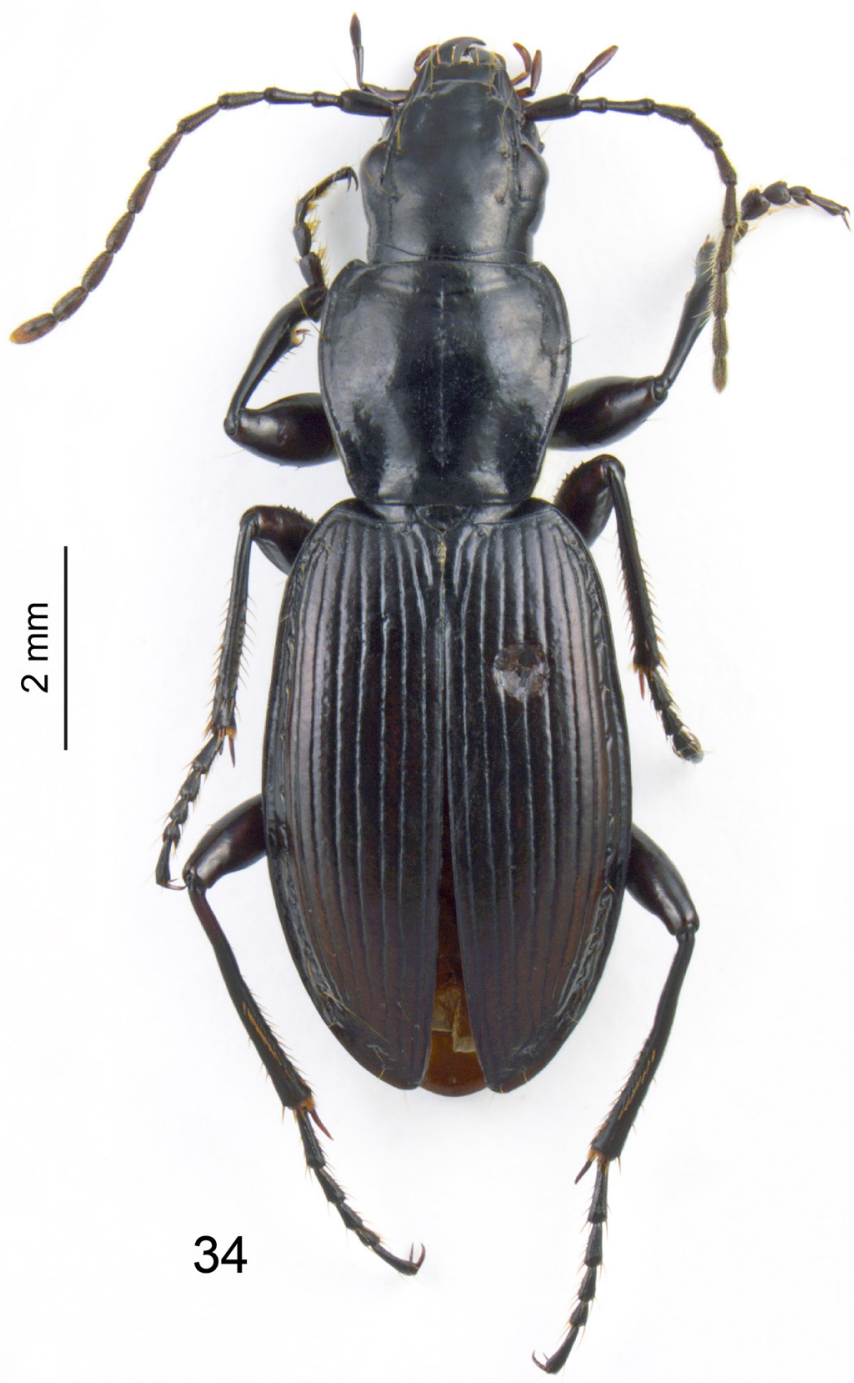

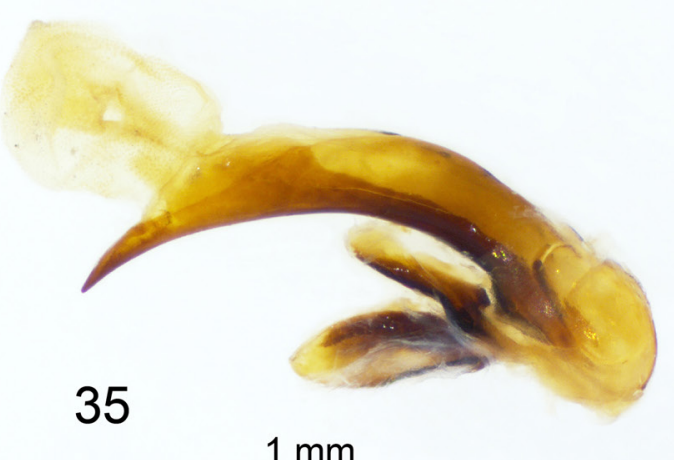

$1 \mathrm{~mm}$

Figs 32-35. 32-33. Dyscolus salazarae Moret sp. nov. 32. Habitus of the male holotype (MNHN, COI voucher PM392-09). 33. Aedeagus, median lobe in lateral view. 34-35. D. ruizi Moret sp. nov. 34. Habitus of a male paratype from Saraguro (CPM). 35. Aedeagus, median lobe in lateral view. 
elongate, convex; sides weakly arcuate anterad, almost straight in basal fourth, with a very short sinuation at level of the basal seta, hind angles obtuse and blunt, anterior angles pronounced, broadly rounded; two pairs of lateral setae. Elytra elongate, subparallel; base relatively narrow, shoulders rounded; sides arcuate apically without subapical sinuation; striae entire, well impressed, not punctate; intervals slightly convex. Third elytral interval asetose. Legs rather short, meso- and metatarsomeres 1-3 with a lateral sulcus on each side; fourth metatarsomere with one pair of dorsolateral subapical setae, its apical lobes very short, the outer lobe twice as large as the inner lobe; fifth metatarsomere asetose ventrally. Last visible abdominal ventrite of the male with one pair of setae along its apical margin. Male genitalia: Fig. 33. Median lobe almost straight in its basal half, shortly arcuate before apex; apex slightly reflexed upward, narrow and acute in lateral view; endophallus without sclerotized structure. Female genitalia: unknown.

\section{Comparisons}

Closely related to $D$. moreti Perrault, 1993, but smaller (most specimens of $D$. moreti range from 10 to $11 \mathrm{~mm}$ ), the lateral margin of the pronotum narrower, the elytra narrower and less convex, the apex of the aedeagus shorter, more acute, and not bent ventrally as in D. moreti.

\section{Habitat}

Upper montane forest on the Eastern slope of the Andes, at around $2850 \mathrm{~m}$ a.s.l.

\section{Geographic distribution}

Only known from the type locality in Southern Ecuador. Probably microendemic.

\section{Riparian species of the páramo}

Dyscolus arauzae Moret sp. nov., D. piscator Moret sp. nov. and D. placitus Moret sp. nov. belong to the group of $D$. hirsutus Moret, 2005, which differs from all the other equatorial clades of Dyscolus by the combination of four characters: elongate body with slender appendages; ventral abdominal sclerites entirely or partly reddish; submentum with supernumerary setae; fifth elytral interval with setae. Dyscolus hirsutus was described on specimens from two distant páramos, both in the Eastern Cordillera: Guamaní and El Altar, $150 \mathrm{~km}$ apart. A closer examination of the type series shows that the Guamaní population (North) and the El Altar population (South) belong to two different species. As the holotype of $D$. hirsutus came from El Altar, the Northern population had to be described as new. It has been named $D$. placitus Moret sp. nov. Furthermore, the material collected in 2015-2017 revealed the existence of a second species, D. piscator Moret sp. nov., sympatric with D. placitus Moret sp. nov. at Guamaní ca $3900 \mathrm{~m}$ a.s.l., but living in a different microhabitat. A third species closely related to D. piscator Moret sp. nov.and D. placitus Moret sp. nov., D. arauzae Moret sp. nov., lives at a higher elevation (4300 m a.s.1.) on Mt Cayambe.

A fourth riparian species, D. gobbii Moret sp. nov., from high elevations (4200-4400 m a.s.1.) in the Guamaní and Antisana areas, belongs to a different clade. It has a more robust morphotype than the members of the hirsutus group, with a broad, convex body and short legs.

Dyscolus placitus Moret sp. nov. urn:1sid:zoobank.org:act:02B83689-1D33-4C9B-85D2-8D6316CBD0FE

Figs 38, 41 (above)

Dyscolus hirsutus Moret, 2005: 151, pro parte.

\section{Etymology}

Latin adjective meaning 'nice, pleasant'. 


\section{Type material}

\section{Holotype}

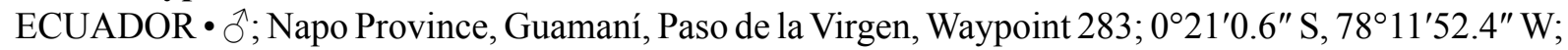
3890 m a.s.l.; 11 Mar. 2017; P. Moret and M. Gobbi leg.; MNHN.

Paratypes $(2 \hat{\jmath} \hat{\partial}, 1$ ㅇ)

ECUADOR • 1 ते; same collection data as for holotype; CPM 1 1 ; same collection data as for holotype; QCAZ 256725 • 1 đ ( red label: "Dyscolus (Hydrodyscolus) hirsutus Moret, Paratype"); Napo Province, Paso de Papallacta (Guamaní), 3810 m a.s.l.; 13 May 1982; H. Frania and F. Sperling leg.; under stones and logs near stream; UASM.

\section{Diagnostic description}

Habitus: Fig. 38. Wingless. Body length: 8.8-9.6 mm. Dorsal surface of the body entirely dark brown; ventral surface mostly dark brown, with reddish areas on the sides of the abdominal sclerites and on most parts of the coxae and trochanters; legs, antennae and mouthparts reddish brown. Elytral microsculpture made of slightly oblong sculpticells. Head convex, collar constriction strong, eyes moderately bulging, genae flat in dorsal view, mandibles moderately long and acute; submentum with two or three pairs of setae, mentum with one pair of setae. Pronotum cordiform, hind angles right angled, blunt; two pairs of lateral setae. Elytra elongate-oval, narrow, without subapical sinuation, rounded at apex; humeri almost entirely effaced. Striae well impressed, intervals feebly convex. Third interval with 3-6 setae, fifth interval with $0-3$ setae, seventh interval with 0 or 1 seta; 17 to 20 umbilicate setae along the lateral margin. Last visible abdominal ventrite with one pair $(\delta)$ or two pairs $(+)$ ) of setae along its apical margin. Legs slender; fourth metatarsomere without subapical dorsolateral setae, apical lobes parallel, the outer lobe 1.5 times longer than the inner lobe. Male genitalia: Fig. 41. Apex of the median lobe bent downwards; endophallus without sclerotized structure. Female genitalia: unstudied.

\section{Comparisons}

Dyscolus hirsutus, now geographically restricted to the El Altar volcano, differs from D. placitus Moret sp. nov. by the following characters: upper surface bicolorous with the head and the elytra dark brown, the pronotum reddish; ventral surface (including the epipleura) entirely reddish, except for the head which is dark brown; mandibles with a long and very acute tip; eyes more bulging; hind angles of the pronotum broadly rounded; humeri more effaced; seventh interval with 1 or 2 setae; apex of the median lobe broader, apically rounded (slightly hooked in D. placitus Moret sp. nov.). The differences with D. arauzae Moret sp. nov. and D. piscator Moret sp. nov. are set forth in the diagnoses of these species.

\section{Habitat}

Hygrophilous in the upper montane forest, at around 3800-3900 m a.s.1. The specimens collected in 2017 were found in the understory of a Polylepis forest, beneath soaked mosses on the ground.

\section{Geographic distribution}

Microendemic species, restricted to the Guamaní area in the Eastern Cordillera.

Dyscolus piscator Moret sp. nov. urn:1sid:zoobank.org:act:C207DE54-A6E2-4C10-AF45-EDBE8BAF3D22

Figs 37, 40, 41 (below)

\section{Etymology}

Latin adjective meaning 'fisherman', in allusion to the feeding habits of this riparian species which preys on small water invertebrates. 


\section{Type material}

\section{Holotype}

ECUADOR • ${ }^{`}$; Napo Province, Guamaní, Paso de la Virgen, Waypoint 283; $0^{\circ} 21^{\prime} 0.6^{\prime \prime}$ S, $78^{\circ} 11^{\prime} 52.4^{\prime \prime}$ W; 3890 m a.s.l.; 11 Mar. 2017; P. Moret and M. Gobbi leg.; QCAZ.

\section{Paratypes $(2 \hat{\jmath}, 1$ \& $)$}

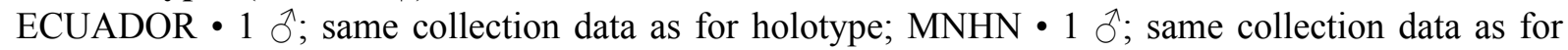
holotype; CPM 1 \% ; same collection data as for holotype; COI voucher in ethanol PM283-01, BOLD sequence SUM239-18; CPM.

\section{Diagnostic description}

Habitus: Fig. 37. Wingless. Body length: 9.6-10.9 mm, bigger than D. placitus Moret sp. nov. Ventral surface paler, abdominal ventrites entirely reddish-testaceous. Elytral microsculpture slightly less transverse. Head bigger, genae slightly but distinctly convex in dorsal view (flat in D. placitus Moret sp. nov.); apex of the labrum bisinuate (straight in D. placitus Moret sp. nov.); mandibles much longer, finely acute at apex (length of the right mandible / width of the frons between the anterior setae $=0.95$ in D. piscator Moret sp. nov., 1.21 in D. placitus Moret sp. nov.). Third elytral interval with 3-4 setae, fifth interval with 2-4 setae, seventh interval with 0-1 seta; 11-13 umbilicate setae along the lateral margin (17-20 in D. placitus Moret sp. nov.). Male genitalia: Fig. 40. Apex of the median lobe slightly curved, not strongly bent downwards as in D. placitus Moret sp. nov., with a rounded tip, not hooked as in D. placitus Moret sp. nov.

\section{Habitat}

Riparian in the upper montane forest with Polylepis, at around $3900 \mathrm{~m}$ a.s.l. Under stones at the edge of a small stream. This biotope is $50 \mathrm{~m}$ away from that of $D$. placitus Moret sp. nov.

\section{Geographic distribution}

Microendemic species, restricted to the Guamaní area in the Eastern Cordillera.

Dyscolus arauzae Moret sp. nov.

urn:1sid:zoobank.org:act:B992F8BA-69F8-4591-A010-440432759483

Figs 36,39

\section{Etymology}

Noun in the genitive case, dedicated to María de los Ángeles Aráuz who took part in the discovery of this species.

\section{Type material}

\section{Holotype}

ECUADOR • ${ }^{\top}$; Pichincha Province, Volcán Cayambe SW, Waypoint $73 ; 0.006962^{\circ} \mathrm{N}, 78.020278^{\circ} \mathrm{W}$; 4405 m a.s.1.; 30 Oct. 2015; P. Moret and M. Aráuz leg.; QCAZ.

$$
\text { Paratypes }(6 \hat{\jmath} \widehat{\partial}, 6 \text { 우) }
$$

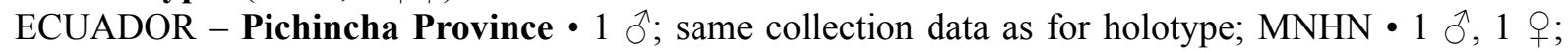
same collection data as for holotype; CPM $\bullet 1$ \%; same collection data as for holotype; COI voucher PM073-03, BOLD sequence SUM020-18; CPM • 1 ð’; Volcán Cayambe SW, Waypoint 77; $0.007724^{\circ} \mathrm{N}$, $78.023350^{\circ} \mathrm{W} ; 4300 \mathrm{~m}$ a.s.1.; 30 Oct. 2015; P. Moret and M. Aráuz leg.; COI voucher PM077-01, BOLD sequence SUM099-18; CPM • $3 \partial^{\lambda} \partial^{\lambda}, 2$ 우; Volcán Cayambe SW, Waypoint 267; 000.415’ N, 

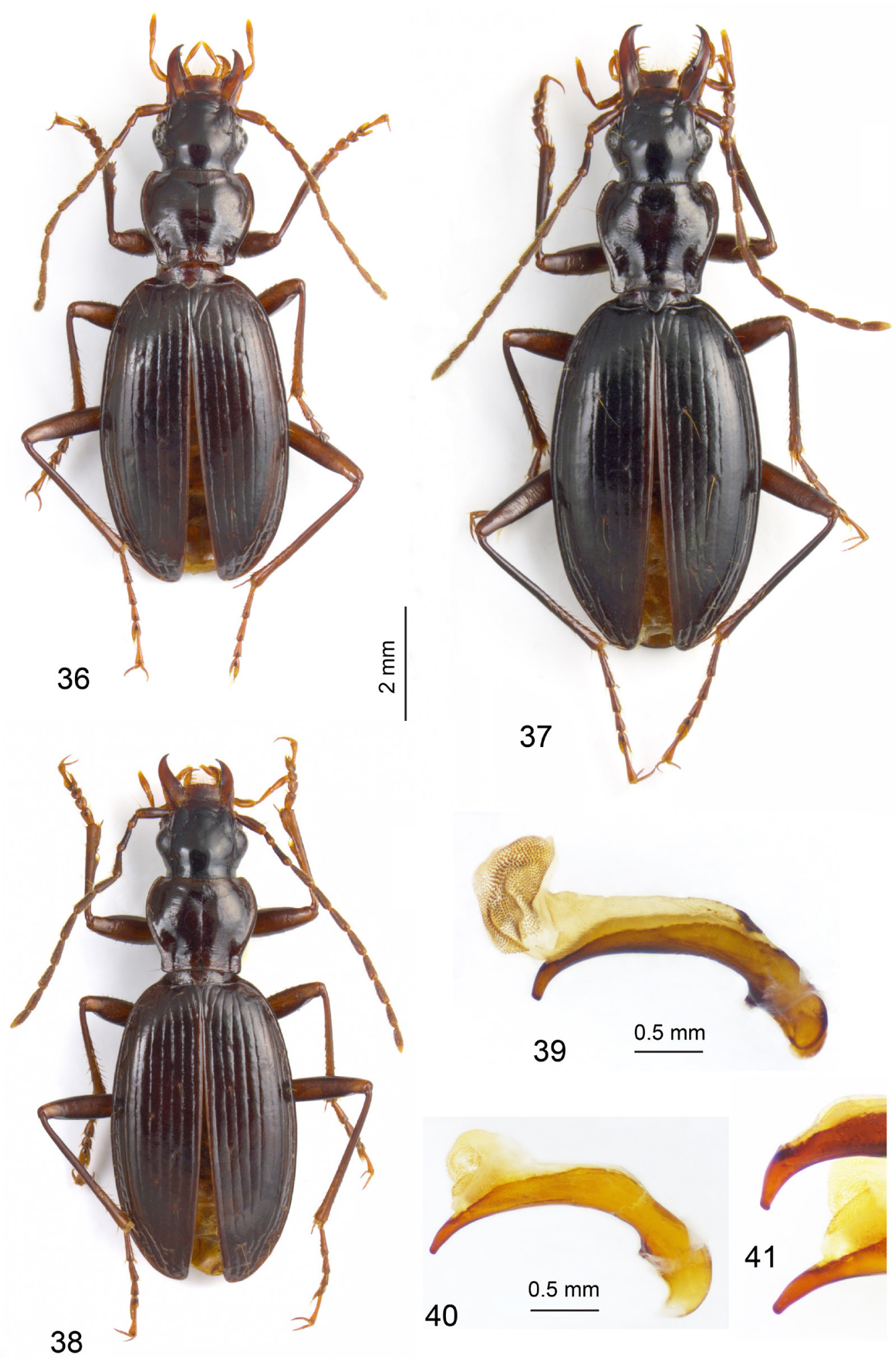

Figs 36-41. Dyscolus spp., habitus (36-38) and aedeagus, median lobe in lateral view (39-40) and apex of the median lobe (41). 36. Dyscolus arauzae Moret sp. nov., male holotype (QCAZ). 37. D. piscator Moret sp. nov., male holotype (QACZ). 38. D. placitus Moret sp. nov., male holotype (MNHN). 39. D. arauzae Moret sp. nov. 40. D. piscator Moret sp. nov. 41. D. placitus Moret sp. nov. (above) and D. piscator Moret sp. nov. (below). 
78¹.338' W; 4294 m a.s.1.; 4 Mar. 2017; P. Moret and M. Gobbi leg.; CPM • 1 q (in ethanol); Volcán Cayambe SW, Waypoint 76; 0.006860 ${ }^{\circ}$ N, 78.020714 ${ }^{\circ} \mathrm{W}$; $4390 \mathrm{~m}$ a.s.1.; 18 Jul. 2016; P. Moret and E. Moreno leg.; CPM • 1 क (in ethanol); same collection data as for preceding; 4 Mar. 2017; P. Moret and M. Gobbi leg.; CPM.

\section{Diagnostic description}

Habitus: Fig. 36. Wingless. Body length: $8.5-10.9 \mathrm{~mm}$. Antennae unicoloured, testaceous, as in D. hirsutus (apical part of the antennomeres darker in D. piscator Moret sp. nov. and D. placitus Moret sp. nov.). Colour of the ventral face variable. Dimensions of the head intermediate between $D$. piscator Moret sp. nov. and D. placitus Moret sp. nov. (length of the right mandible / width of the frons between the anterior setae $=1.05$ ). Apex of the labrum straight. Lateroposterior seta of the pronotum close to the hind angle (slightly shifted forward in D. piscator Moret sp. nov. and D. placitus Moret sp. nov.). Third elytral interval with 4-7 setae, fifth interval with 2-4 setae, seventh interval normally without setae, only one paratype with one seta; $15-17$ umbilicate setae along the lateral margin (11-13 in D. piscator Moret sp. nov., 17-20 in D. placitus Moret sp. nov.). Male genitalia: Fig. 39. Apex of the median lobe bent downwards, resembling that of D. placitus Moret sp. nov.; apical part of the endophallus covered with sclerotized squamae (unarmed in D. piscator Moret sp. nov. and D. placitus Moret sp. nov.).

\section{Habitat}

Riparian along glacier-fed streams in the humid superpáramo at 4300-4400 m a.s.l.

\section{Geographic distribution}

Microendemic species, presumably restricted to the Cayambe mountain.

Dyscolus gobbii Moret sp. nov. urn:1sid:zoobank.org:act:787DC50E-8874-4E7F-BCAD-FE33230508A1

Fig. 42

\section{Etymology}

Noun in the genitive case, dedicated to Mauro Gobbi, specialist of the ecology of glacier-foreland invertebrates, who took part in the discovery of this species.

\section{Type material}

\section{Holotype}

ECUADOR - 9 ; Pichincha Province, Guamaní, Paso de la Virgen, Waypoint 210; 0¹9'18.3" S, 78¹1'54.8" W; 4230 m a.s.1.; 27 Feb. 2017; P. Moret and M. Gobbi leg.; COI voucher PM210-16, BOLD sequence SUM228-18; QCAZ.

\section{Paratype}

ECUADOR • 1 q; Pichincha Province, Volcán Antisana NW, B1C3; $0.457780^{\circ} \mathrm{S}, 78.167970^{\circ} \mathrm{W}$; 4401 m a.s.l.; 22 Apr. 2016; E. Moreno leg.; COI voucher in ethanol PM188-01, BOLD sequence SUM183-18; CPM.

\section{Diagnostic description}

Habitus: Fig. 42. Wingless. Body length: $10.2 \mathrm{~mm}$ (holotype) to $12.3 \mathrm{~mm}$ (paratype). Body piceous black, legs brownish with reddish-brown femora. Elytral microsculpture made of oblong sculpticells, shallowly impressed. Head big, convex dorsally; mandibles long and sharp, as long as the length of the head from base to apex of the labium; eyes moderately bulging, genae oblique, slightly convex in 
dorsal view. Pronotum transverse, subquadrate, narrower at base than at apex; lateroapical lobes broadly rounded; hind angles obtusely rounded; two pairs of lateral setae. Elytra oval-shaped, convex, with effaced humeri. Striae weakly impressed, with traces of punctuation; intervals $1-4$ slightly convex, 5-8 flat; third interval with five or six discal setae. Last visible abdominal ventrite of the female with
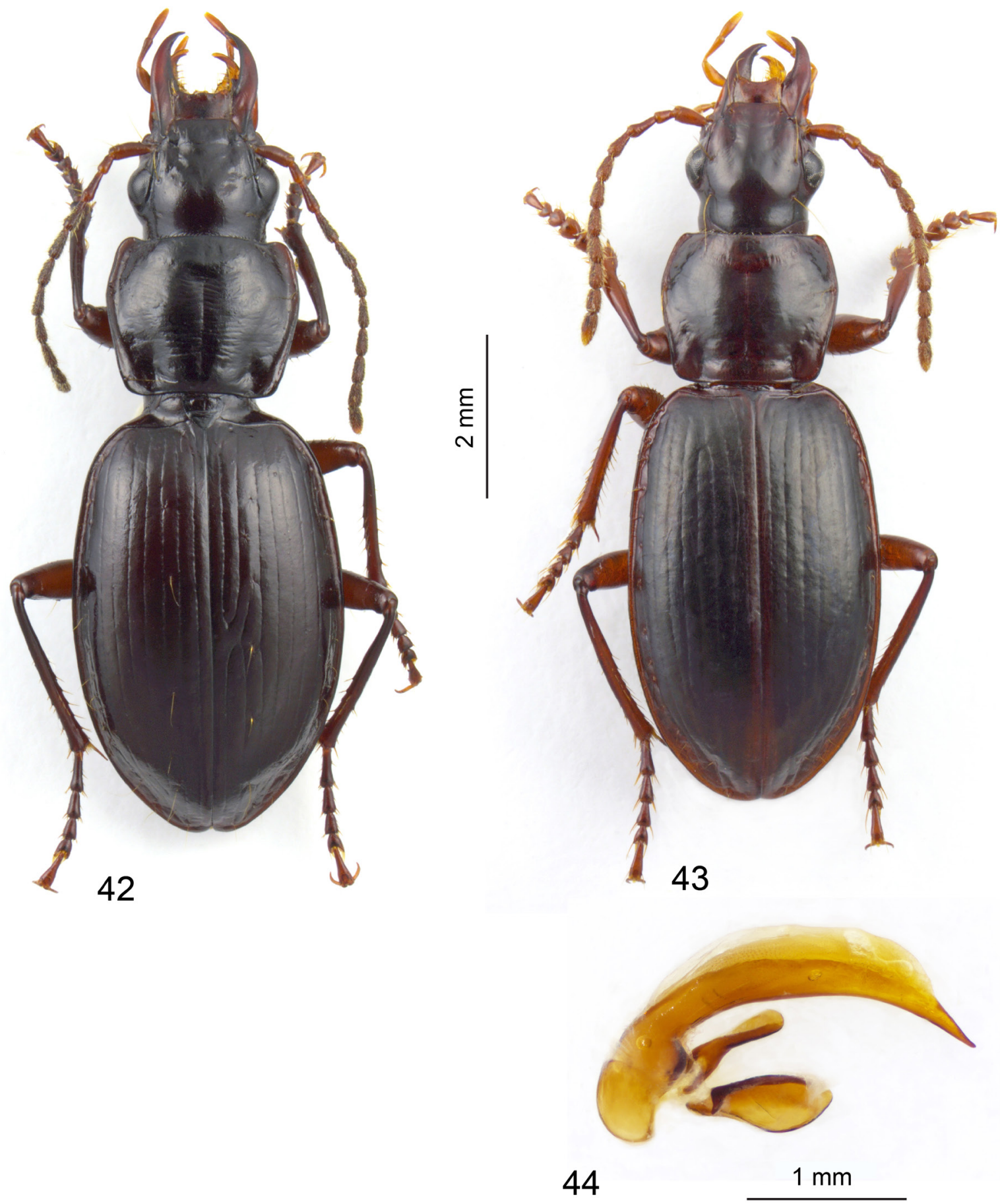

Figs 42-44. 42. Dyscolus gobbii Moret sp. nov., habitus of the female holotype (QACZ, COI voucher PM210-16). 43-44. D. barragani Moret sp. nov. 43. Habitus of the male paratype (CPM, COI voucher PM417-02). 44. Aedeagus, median lobe in lateral view. 
two pairs of setae along its apical margin. Legs slender but short; fourth metatarsomere with convex sides, without subapical dorsolateral setae (holotype) or with weak and short subapical dorsolateral setae (paratype), apical lobes ovoid, the outer lobe slightly longer than the inner lobe. Male genitalia: unknown. Female genitalia: unstudied.

\title{
Comparisons
}

This isolated species remotely resembles Dyscolus segnipes Moret, 1990, with which it coexists in the Guamaní páramo. Dyscolus segnipes has much shorter mandibles and well developed subapical dorsolateral setae on the fourth metatarsomere. The COI tree places gobbii and segnipes in two clades far apart from each other.

\section{Habitat}

Humid superpáramo, from 4200 to $4400 \mathrm{~m}$ a.s.l. The Guamaní specimen was collected under a stone on the shore of a small lake; the Antisana specimen was collected by pitfall trapping in a mesic environment, 20 metres from a glacier-fed stream.

\section{Geographic distribution}

Microendemic species, restricted to the Antisana and Guamaní areas in the Eastern Cordillera.

\section{Non-riparian species of the páramo}

\author{
Dyscolus barragani Moret sp. nov. \\ urn:lsid:zoobank.org:act:ACA0E4AD-2254-492D-9BD9-0107CDD395F6
}

Figs 43-44

\section{Etymology}

Noun in the genitive case, dedicated to Álvaro Barragán, associate professor of entomology at the Pontificia Universidad Católica del Ecuador, co-organizer of the research project that led to the discovery of most of the new species described here.

\section{Type material}

\section{Holotype}

ECUADOR - ô; Chimborazo Province, Ayapungu, Cerro Púlpito, Waypoint 417; $2^{\circ} 18^{\prime} 16.2^{\prime \prime}$ S, 78³4'33.4" W; 4290-4320 m a.s.1.; 24 Mar. 15; P. Moret and A. Barragán leg.; QCAZ.

\section{Paratype}

ECUADOR - 1 ð’; Chimborazo Province, Ayapungu, Cerro Púlpito, Waypoint 416; 2¹8'29.0" S, 78³4'38.8" W; 4180 m a.s.1.; 24 Mar. 15; P. Moret and A. Barragán leg.; COI voucher PM417-02, BOLD sequence SUM021-18; CPM.

\section{Diagnostic description}

Habitus: Fig. 43. Wingless. Body length: 8.9-9.2 mm. Body with a varying coloration, from reddish brown to piceous black, the sides of the pronotum and of the elytra lighter than the discal area; legs, antennae and mouthparts testaceous to reddish brown. Elytral microsculpture isodiametric, distinctly impressed. Head broad and convex, neck markedly constricted, eyes moderately bulging, genae oblique, almost flat in dorsal view; antennae moniliform, very short. Pronotum transverse, quadrate; lateroapical lobes small, not protruding; sides feebly arcuate distally, almost straight in basal third; hind angles bluntly obtuse, almost rounded; two pairs of lateral setae. Elytra subparallel, convex; preapical sinuation obsolete; striae fine and shallowly impressed, almost obsolete; intervals flat or subconvex; third elytral 
interval without discal setae. Legs short and robust; fourth metatarsomere triangular, with one pair of apical dorsolateral setae; apical lobes very short, the outer lobe slightly larger than the inner lobe; fifth metatarsomere asetose ventrally. Last visible abdominal ventrite of the male with one pair of setae along its apical margin. Male genitalia: Fig. 44. Median lobe weakly arcuate with a long apical blade, endophallus unarmed. Female genitalia: unknown.

\section{Comparisons}

This species closely resembles Dyscolus saxatilis Moret, 1993 in its general sturdy aspect, asetose third elytral interval, shallow striae, and in the form of the fourth metatarsomere. It differs from it by its smaller size (D. saxatilis: 10.0-10.8 mm), elytral microsculpture less granulose, eyes bigger, genae shorter and flat (convex in D. saxatilis), lateroapical lobes of the pronotum smaller. Our molecular analysis (Fig. 2) puts D. barragani Moret sp. nov. closer to D. hebeculus (Bates, 1891), with a very weak bootstrap support. Dyscolus hebeculus shares with D. barragani Moret sp. nov. an asetose third elytral interval, but otherwise the morphological differences are many. Dyscolus hebeculus has smaller eyes, longer antennae, a more elongate pronotum with more developed hind angles, elytral striae well impressed, and markedly asymmetrical lobes at the apex of the fourth metatarsomere.

\section{Habitat}

Humid superpáramo, at around $4300 \mathrm{~m}$ a.s.1.

\section{Geographic distribution}

Microendemic species, restricted to the Ayapungu massif.

\section{Dyscolus denigratus (Bates, 1891)}

Figs $45-50$

Colpodes denigratus Bates, 1891: 17.

Dyscolus palatus Moret, 1998: 18. syn. nov.

Dyscolus (Dyscolus) denigratus - Moret 2005: 128.

Dyscolus (Dyscolus) palatus - Moret 2005: 130.

Dyscolus denigratus is a highly variable species, with a broad range of variation within each population regarding body size, form of the pronotum, length of the legs, and form of the apex of the male aedeagus (Figs 45-46, 48-50). The tree based on the COI sequences separates two clades (Fig. 2): one in the south-west part of the area of $D$. denigratus, represented in our dataset by the Cotopaxi and Pichincha populations, vs a north and north-east zone represented by the Cotacachi, Cayambe and Guamaní populations. Additionally, three species-level units are recognized through BIN analysis: the first one embraces the populations of the south-western clade, including specimens identified as D. palatus. The northern clade is split into two BIN units: one for the Guamaní population, and another for the Cotacachi and Cayambe populations. However, we were unable to find any morphological character that reliably reflects these divisions. According to the form of the apex of the median lobe, the Cotacachi population (Fig. 49) seems to be closer to the Pichincha population (Fig. 50) than to the Guamaní one (Fig. 48), in contradiction with the molecular results. Obviously, the phylogeny of the denigratus complex cannot be resolved from the COI sequences alone.

We thus take a conservative approach, with no taxonomic decision regarding the specific or subspecific status of the components of the denigratus complex, except for the synonymy of Dyscolus palatus with Dyscolus denigratus. Dyscolus palatus was described from specimens from the Pichincha, Atacazo and 

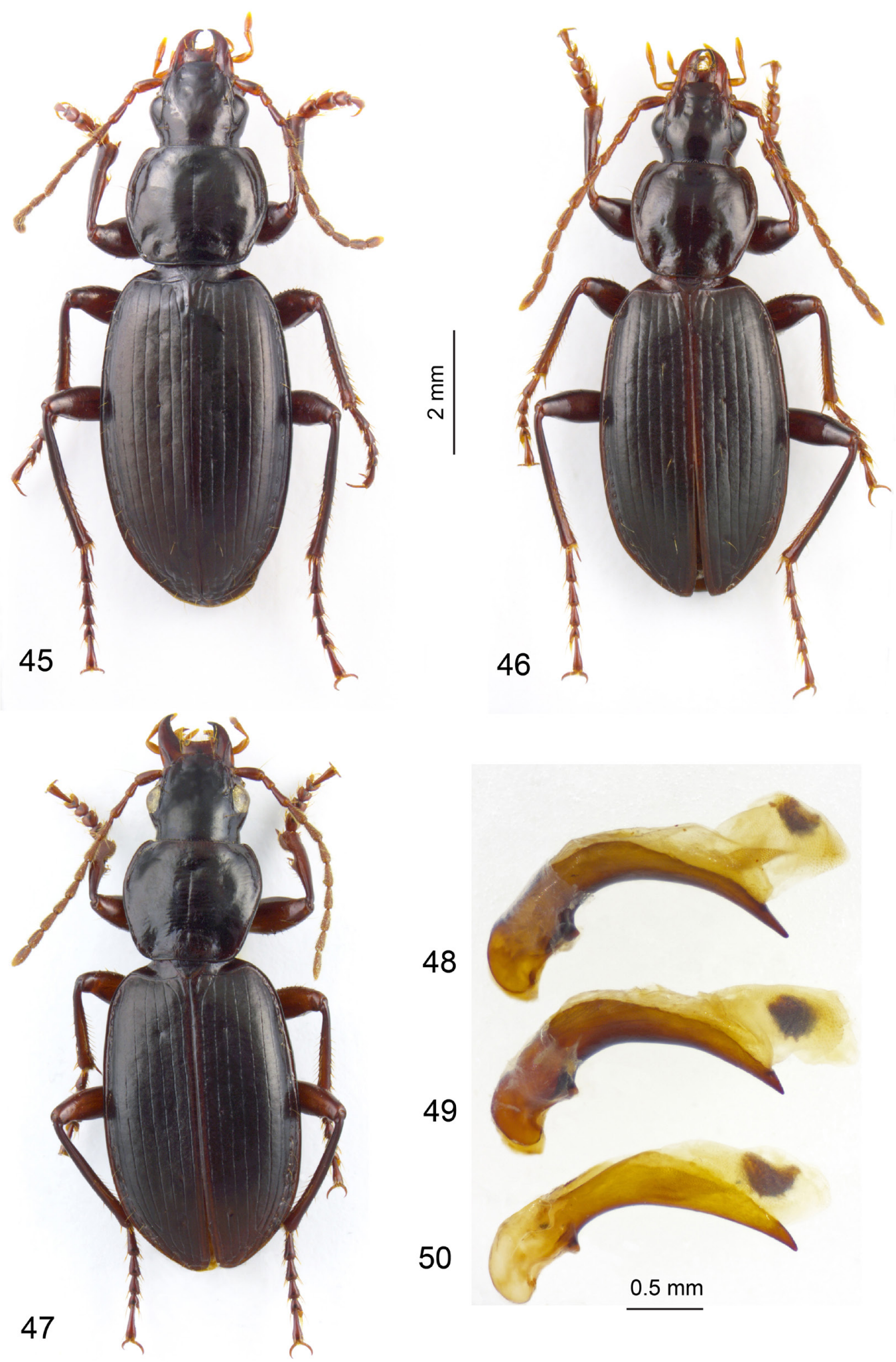

Figs 45-50. Dyscolus spp., habitus (45-47) and aedeagus, median lobe in lateral view (48-50). 45. D. denigratus (Bates, 1891), male specimen from Guamaní. 46. D. denigratus, male specimen from Guagua Pichincha (type locality). 47. D. palatus Moret, 1998, male paratype from Atacazo. 4850. D. denigratus. 48. From Guamaní. 49. From Cotacachi. 50. From Guagua Pichincha. 


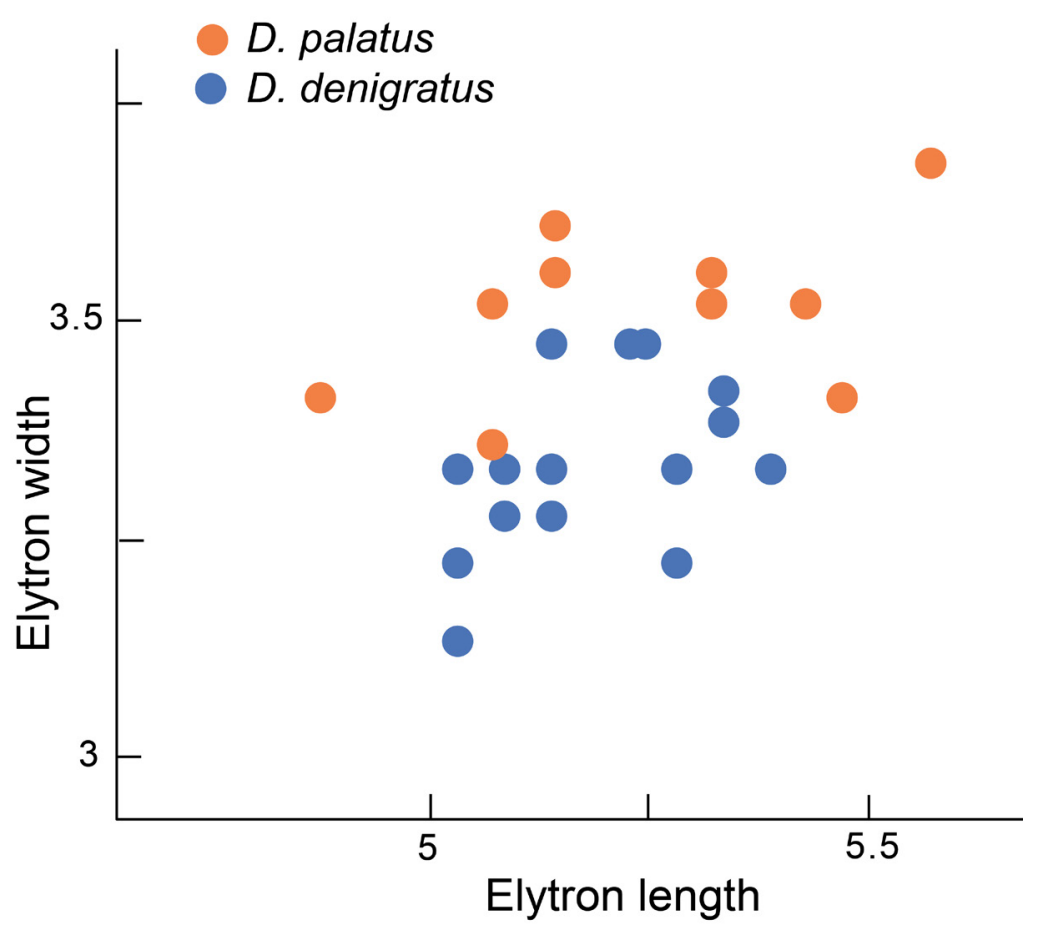

Fig. 51. Compared dimensions of the elytra of Dyscolus denigratus (Bates, 1891) and D. palatus Moret, 1998.

Corazón volcanoes in the Western Cordillera (Fig. 47). This taxon was then thought to be more closely related to $D$. altarensis (Bates, 1891) than to $D$. denigratus, due to its relatively broader and shorter body. The specimen of $D$. palatus included in our analysis (COI voucher PM359-01, BOLD sequence SUM16818 ) instead suggests that $D$. palatus and $D$. denigratus are conspecific. A re-examination of the type series of $D$. palatus and of large series of specimens recently collected on the Pichincha shows that the body dimensions of the two taxa partly overlap (Fig. 51). Owing to the existence of these transition forms, $D$. palatus cannot be maintained as a good species and we therefore treat it as a synonym of $D$. denigratus.

Dyscolus silvestris Moret sp. nov. urn:1sid:zoobank.org:act:8DA5B9B7-F332-4D75-AC2D-CEBBD34ADA3C

Figs $52-53$

\section{Etymology}

Latin adjective meaning 'forest related'.

\section{Type material}

\section{Holotype}

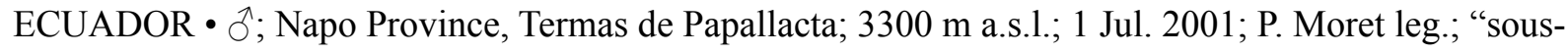
bois"; QCAZ.

\section{Paratypes $(5 \hat{o} \hat{\partial}, 10$ 우 $)$}

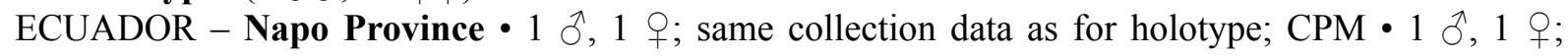
Papallacta, Termas Jamanco, Waypoint 41; $0^{\circ} 22^{\prime} 24.6^{\prime \prime} \mathrm{S}, 78^{\circ} 10^{\prime} 5.5^{\prime \prime} \mathrm{W} ; 3410 \mathrm{~m}$ a.s.1.; 25 Oct. 2015; P. Moret leg.; MNHN • 1 \%; same collection data as for preceding; QCAZ $\bullet 1$ ô, 3 우; same collection data as for preceding; CPM $\bullet 1 \hat{\delta}$; same collection data as for preceding; COI voucher PM041-02, 
BOLD sequence SUM103-18; CPM • 1 \%; same collection data as for preceding; COI voucher in ethanol PM041-06, BOLD sequence SUM104-18; CPM • 2 o o o; Lago Papallacta; 3370 m a.s.1.; 9 Apr. 1986; A. Vigna; CPM・ 1 क; Papallacta; 2700 m a.s.l.; 6-8 Apr. 1979; H. Frania leg.; UASM・ 1 §ं; Lago Papallacta; 0²0'29" S, 78¹0'23" W; 3400 m a.s.1.; 6 Nov. 1999; R. Anderson leg.; CMNC.

\section{Diagnostic description}

Habitus: Fig. 52. Wingless. Body length: 9.1-10.0 mm. Body colour variable, predominantly dark brown with reddish brown areas in some specimens; legs, antennae and mouthparts reddish brown. Elytral microsculpture isodiametric. Head broad and convex, neck slightly constricted, eyes moderately bulging. Pronotum subcordiform, the base much narrower than the apex; sides arcuate anterad, markedly sinuate posterad; hind angles obtuse, sharp; two pairs of lateral setae. Elytra subovate, moderately convex; striae entire, well impressed; intervals flat. Third elytral interval with 3-4 discal setae. Legs: protarsi of the male much broader than those of the female. Fifth metatarsomere asetose ventrally. Last visible abdominal ventrite with one pair $\left({ }^{\Uparrow}\right)$ or two pairs $(+)$ of setae along its apical margin. Male

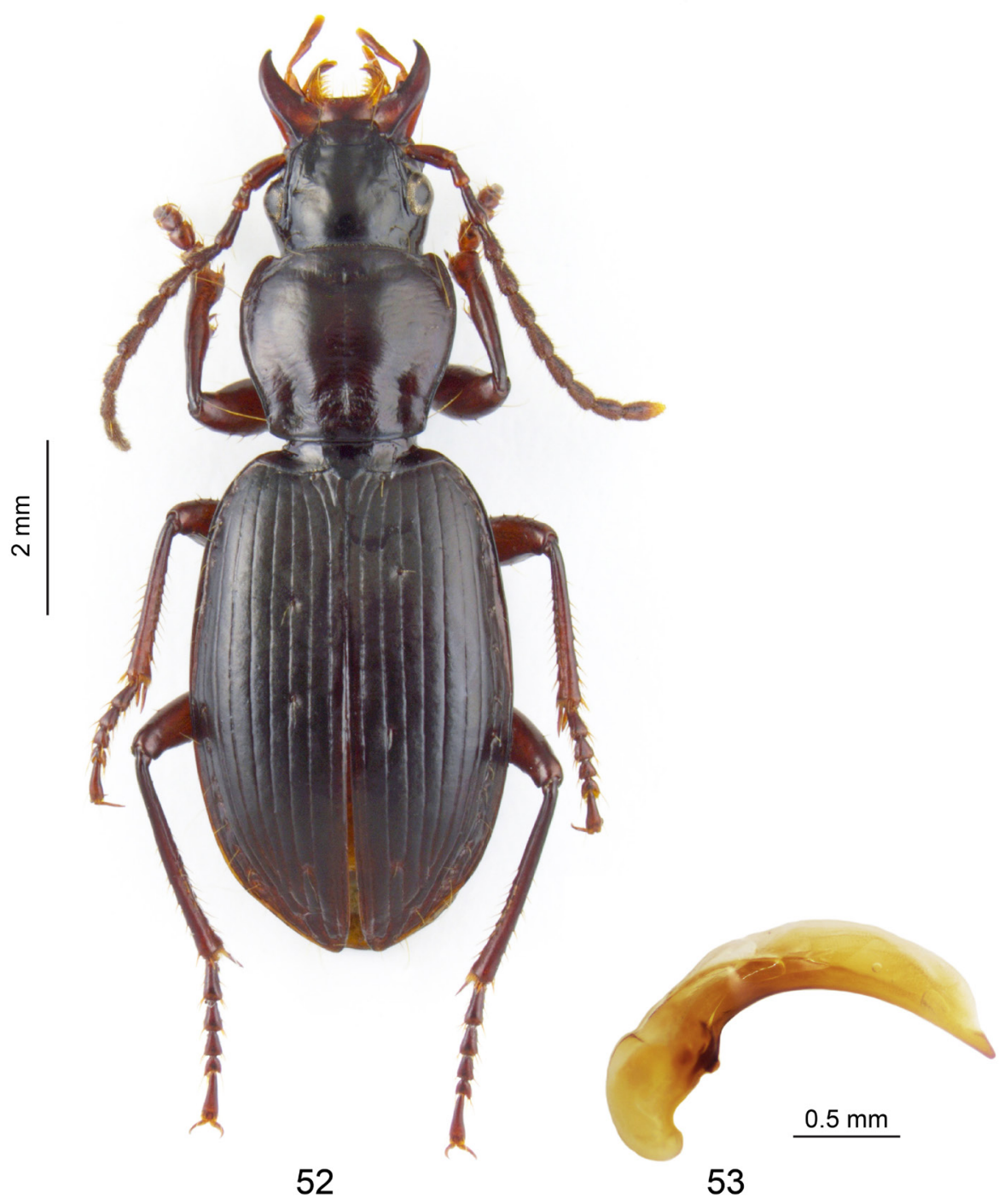

Figs 52-53. Dyscolus silvestris Moret sp. nov., male holotype (QCAZ). 52. Habitus. 53. Male aedeagus, median lobe in lateral view. 
genitalia: Fig. 53. Median lobe arcuate, shortly and bluntly triangular at apex, endophallus unarmed. Female genitalia: unstudied.

\section{Comparisons}

Dyscolus silvestris Moret sp. nov. is similar to the shorter and broader individuals of Dyscolus denigratus. The main differences are: head slightly bigger and broader; sides of the pronotum sinuate basally, hind angles sharply obtuse (completely rounded in D. denigratus); femora of the male not swollen as in D. denigratus. The apex of the median lobe of the male genitalia has a shorter apex, and the endophallus is entirely unarmed (with a heavily sclerotized area in D. denigratus).

\section{Habitat}

Upper montane forest on the Amazonian slope of the Andes, from 2700 to 3400 m a.s.l. This species lives in the leaf litter.

\section{Geographic distribution}

Only known from the type locality around Papallacta in Northern Ecuador, probably microendemic.

\section{The group of Dyscolus verecundus}

Dyscolus verecundus Moret, 1998 was originally thought to be a morphologically variable species, widespread in the northern Andes of Ecuador. The type series includes specimens from five volcanoes: Pichincha, Atacazo, Illiniza, Cotopaxi and Chimborazo. The COI sequences revealed a strong separation between two specimens collected on Mt Pichincha and a third one from Mt Illiniza. The re-examination of the material used to describe this uncommon species confirms the existence of several microendemic taxa, two of which are described herein. Further investigation will probably reveal a highly fragmented pattern, with vicariant species on each mountain.

Furthermore, the two specimens of Mt Pichincha (PM360-01 / SUM194-18 from Rucu Pichincha, the western summit of this mountain, and PM 385-02 / SUM250-18 from Guagua Pichincha, its eastern summit) are also separated by relatively long branches, and the BIN analysis assigns them to different species. However, no morphological differences could be detected between these two populations. The distance from Rucu Pichincha to Guagua Pichincha is only $4 \mathrm{~km}$, with no discontinuity of the páramo ecosystem at the elevations where the specimens have been found (4200 to $4500 \mathrm{~m}$ ). Pending more comprehensive analyses, we kept a conservative position and decided not to split the Pichincha population of $D$. verecundus into two species.

Another important result of the molecular analysis is that D. verecundus is found near the base of the tree, far from the rest of the páramo Dyscolus species, among clades of Central and North America. It shares with these low altitude platynines, traditionally placed in the genus Platynus, an emarginate, triangularshaped fourth metatarsomere, without protruding apical lobes and with dorsal setae in a lateroapical position, two character states that can be considered plesiomorphic, whereas the rest of the páramo lineages of Dyscolus have a bilobed fourth metatarsomere with dorsolateral setae in a subapical position.

Dyscolus verecundior Moret sp. nov.

urn:1sid:zoobank.org:act:DAB1A22E-25D1-438C-AE2E-25542AF7E50F

Figs 54, 58

Dyscolus verecundus Moret, 1998: 20, pro parte.

Dyscolus (Dyscolus) verecundus - Moret 2005: 142, pro parte. 


\section{Etymology}

Comparative form of the Latin adjective 'verecundus', which is the name of a closely related species.

\section{Type material}

\section{Holotype}

ECUADOR - đ̃; Pichincha Province, Volcán Illiniza, ENE slope, Waypoint $136 ; 0.644404^{\circ} \mathrm{S}$, 78.703469 ${ }^{\circ}$ W; $4335 \mathrm{~m}$ a.s.1.; 15 Jul. 2016; P. Moret and A. Barragán leg.; COI voucher in ethanol PM136-04, BOLD sequence SUM062-18; MNHN.

\section{Paratypes $(2 \circlearrowleft ふ)$}

ECUADOR - Pichincha Province - 1 đ (red printed label: "Dyscolus verecundus Moret, 1998, Paratype"); Volcán Illiniza, NE slope; 4080 m a.s.l.; 7 Aug. 1985; P. Moret leg.; Polylepis forest; CPM • 1 ô (red printed label: "Dyscolus verecundus Moret, 1998, Paratype"); E slope of Volcán Corazón; 4450 m a.s.1.; 24 Jan. 1986; P. Moret leg.; CPM.

\section{Diagnostic description}

Habitus: Fig. 54. Wingless. Body length: 10.8-11.0 mm. Body colour variable, from reddish brown to piceous black, the vertex and the sutural zone of the elytra reddish; legs, antennae and mouthparts reddish. Elytral microsculpture isodiametric, distinctly impressed. Head robust, convex, neck strongly constricted, eyes moderately bulging, genae almost flat in dorsal view; antennae short. Pronotum transverse, subquadrate; sides moderately arcuate distally, weakly sinuate in basal third; hind angles variable, obtuse or almost quadrate, but always blunt; two pairs of lateral setae. Elytra subparallel, disc almost depressed; humeri rounded but not effaced, subapical sinuation obsolete; striae thin, shallowly impressed; intervals flat; third elytral interval with 3-5 discal setae. Fourth metatarsomere triangular, with one pair of lateroapical setae and without subapical dorsolateral setae; apical lobes very short, the inner one not extending beyond the insertion point of the lateroapical seta; fifth metatarsomere asetose ventrally. Last visible abdominal ventrite of the male with one pair of setae along its apical margin (ठ). Male genitalia: Fig. 58. Median lobe weakly arcuate; apical blade bluntly triangular in dorsal view; endophallus with two sclerotized squamose areas, ovoid in shape, median and subapical. Female genitalia: unknown.

\section{Comparisons}

This species closely resembles $D$. verecundus, now restricted to Mt Pichincha, its type locality. Dyscolus verecundior Moret sp. nov. differs from $D$. verecundus in a few external and genital characters: genae almost flat (convex in D. verecundus); antennae slightly thicker, the second antennomere of the male 1.41 to 1.49 times as long as wide (1.50 to 1.65 times in $D$. verecundus); fourth metatarsomere thinner, 1.16 to 1.20 times as long as wide (1.07 to 1.13 times in $D$. verecundus); apical blade of the median lobe thinner in lateral view (compare Figs 56-57 and 58); sclerotized areas of the endophallus bigger.

\section{Habitat}

Lower superpáramo from 4080 to $4450 \mathrm{~m}$ a.s.1.

\section{Geographic distribution}

Microendemic species, restricted to the Illiniza and Corazón volcanoes in the Western Cordillera. 


\section{Dyscolus verecundissimus Moret $\mathrm{sp}$. nov.}

urn:lsid:zoobank.org:act:CD4CC133-EF1C-4F71-8F38-0E954A5F94B4

Figs 55, 59

Dyscolus verecundus Moret, 1998: 20, pro parte.

Dyscolus (Dyscolus) verecundus - Moret 2005: 142, pro parte.

\section{Etymology}

Superlative form of the Latin adjective 'verecundus', which is the name of a related species.

\section{Type material}

\section{Holotype}

ECUADOR • Ј ; Chimborazo Province, Volcán Chimborazo Est, moraine; 4470-4530 m a.s.1.; 4 Aug. 1998; P. Moret leg.; MNHN.

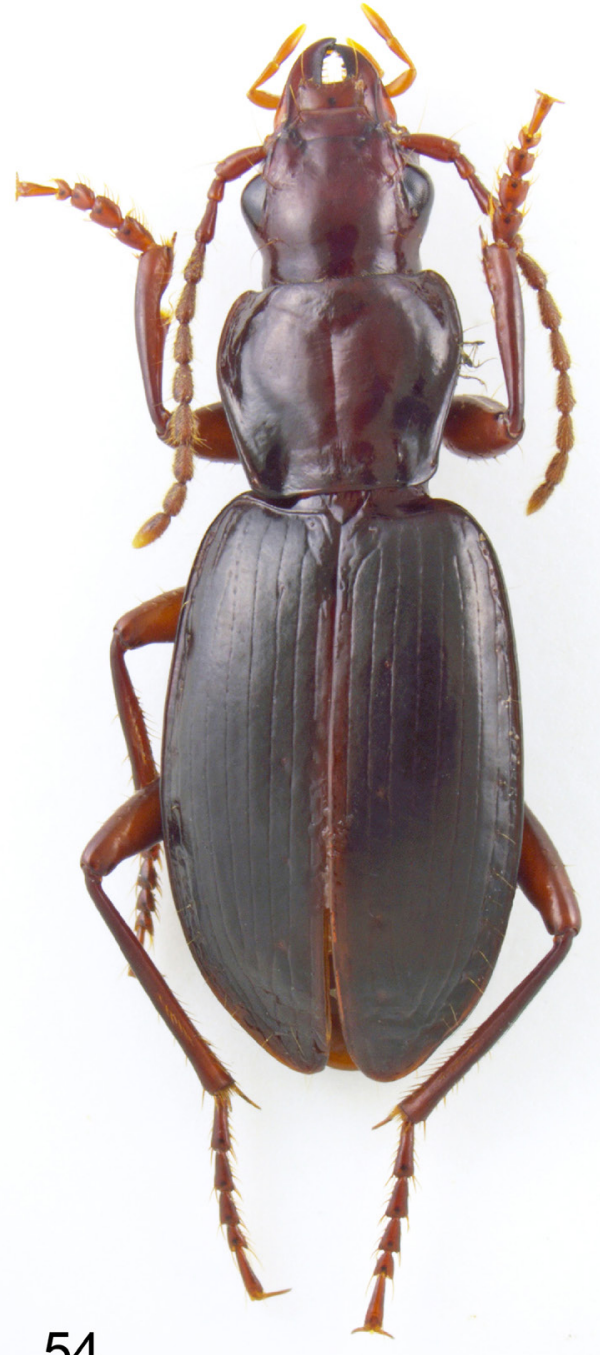

54

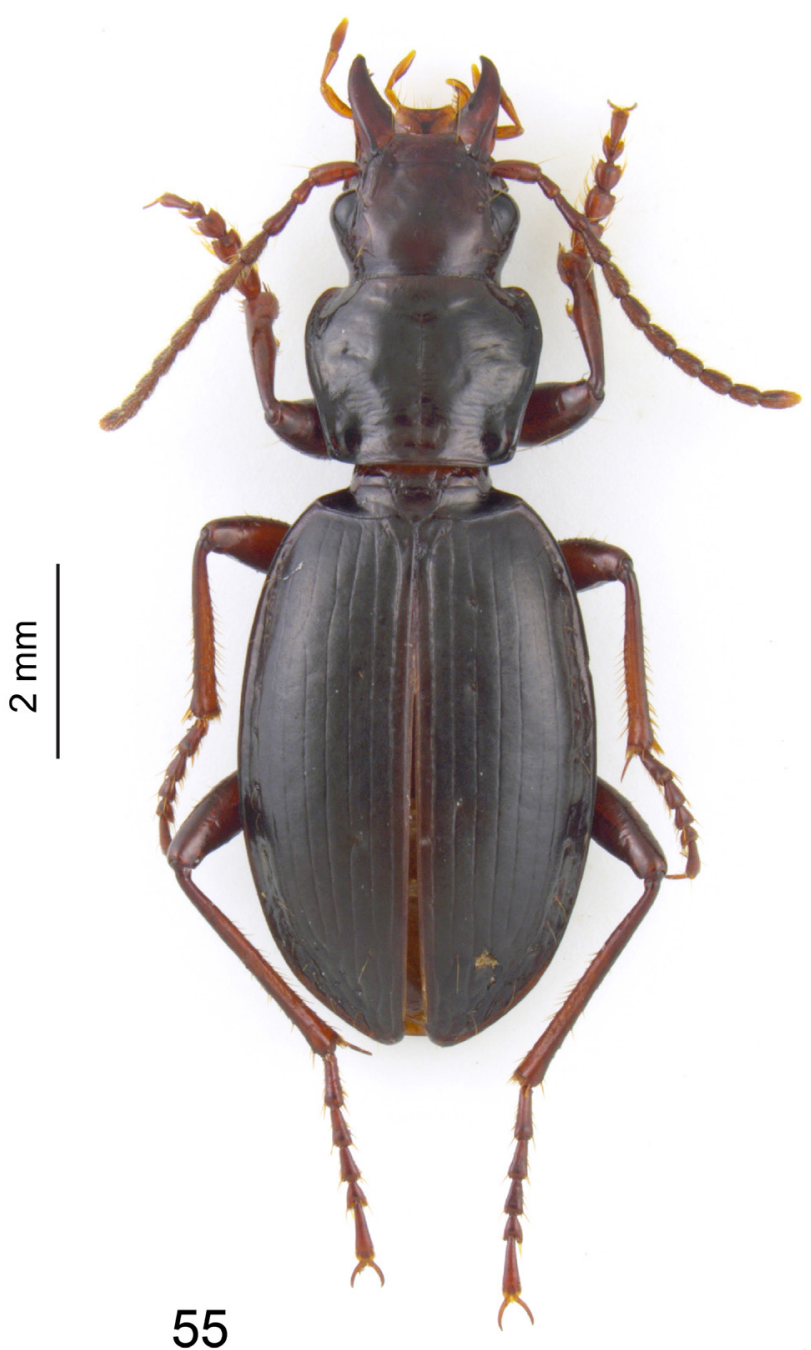

Figs 54-55. Dyscolus spp., habitus. 54. D. verecundior Moret sp. nov., male holotype (MNHN, COI voucher PM136-04). 55. D. verecundissimus Moret sp. nov., male holotype (MNHN). 


\section{Paratype}

ECUADOR • 1 \%; same collection data as for holotype; CPM.

\section{Diagnostic description}

Habitus: Fig. 55. Very similar in almost every aspect to $D$. verecundus and $D$. verecundior Moret sp. nov., so the description will be limited to the few distinctive characters of this new species. Body length: $11.5-11.9 \mathrm{~mm}$, as the biggest specimens of $D$. verecundus; head slightly broader with convex eyes; antennae thinner, the second antennomere 1.76 to 1.77 times as long as wide (1.41 to 1.65 times in $D$. verecundus and $D$. verecundior Moret sp. nov.); pronotum broader, 1.27 to 1.28 times as wide as long (1.13 to 1.24 times in D. verecundus and D. verecundior Moret sp. nov.); apical blade of the median lobe broader and more rounded at apex in dorsal view (Fig. 59); endophallus with a large sclerotized area at middle, and a reduced, almost obsolete squamose area near apex (two sclerotized areas of similar size in $D$. verecundus and D. verecundior Moret sp. nov.).

\section{Habitat}

Humid superpáramo at around $4500 \mathrm{~m}$ a.s.1.
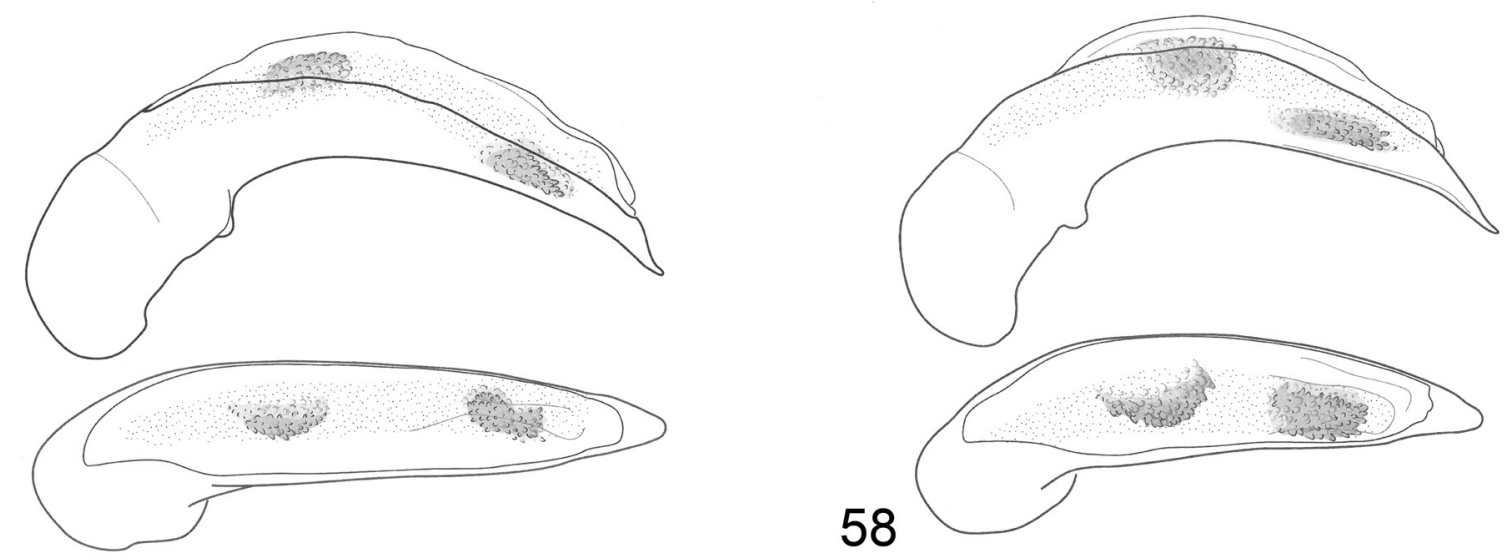

\section{6}
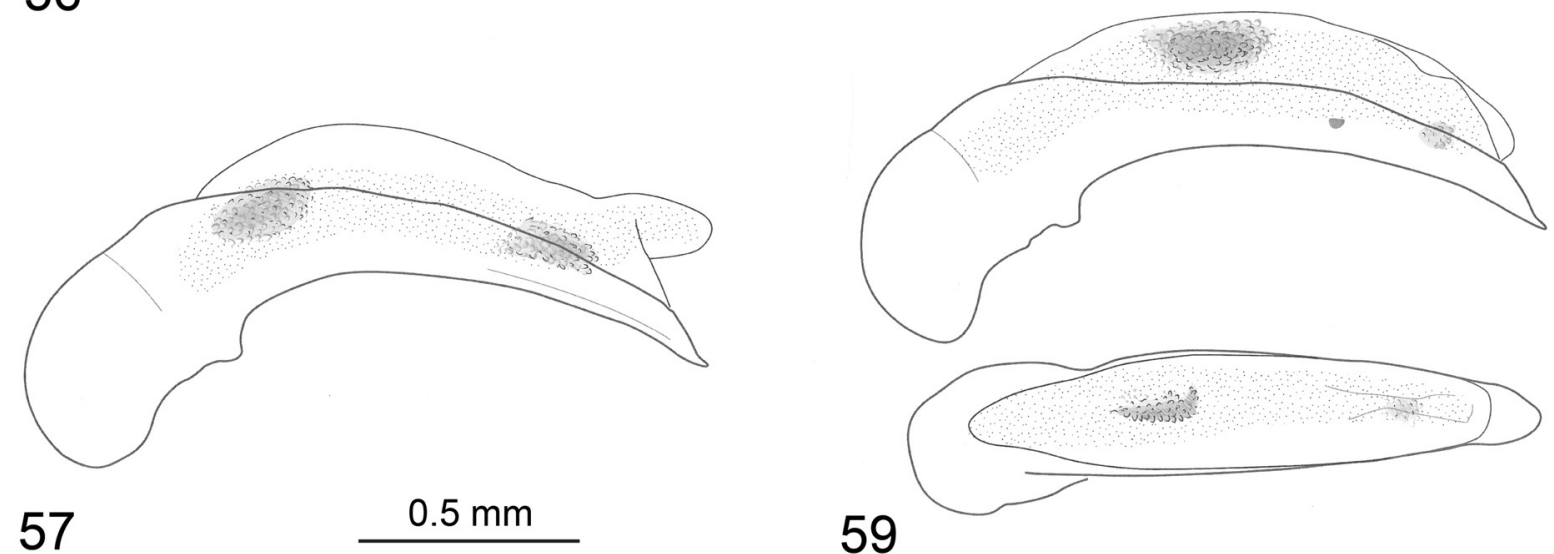

59

Figs 56-59. Group of Dyscolus verecundus Moret, 1998, male aedeagus, median lobe in lateral and dorsal view. 56. D. verecundus, paratype from Rucu Pichincha. 57. D. verecundus, paratype from Guagua Pichincha. 58. D. verecundior Moret sp. nov., holotype (MNHN, COI voucher PM13604);.59. D. verecundissimus Moret sp. nov., holotype (MNHN). 


\section{Geographic distribution}

Microendemic species, restricted to the Chimborazo volcano in the Western Cordillera.

\section{Comments}

The isolated population we raise here to species rank was initially assigned to $D$. verecundus by Moret (2005). There are more morphological differences between $D$. verecundissimus Moret sp. nov. and the pair of sister species $D$. verecundus and $D$. verecundior Moret sp. nov. than between the two latter, especially in the male aedeagus.

\section{Discussion}

The species delimitations generated by the Barcode Index Number (BIN) System (Ratnasingham \& Hebert 2013) are most often congruent with the results of a previous taxonomic study, only based on characters of external and genital morphology (Moret 2005). Discrepancies with the morphology-based identifications occur in 14 cases, out of 64 morphospecies under study. All these cases are examined below, first the cases of species merged by the Bin analysis, then the species split by the BIN analysis. As a general rule, our taxonomic decisions were based on a conservative approach: we only followed the indications of molecular analysis if they have the support of stable and unambiguous morphological characters.

\section{Species merged by the BIN analysis}

In four cases, pairs of taxa are merged into one by BIN assignments: D. denigratus with D. palatus, D. fucatus Moret, 2005 with D. robiginosus Moret, 2005, D. diopsis (Bates, 1891) with D. oreas (Bates, 1891 ) and $D$. aquator Moret sp. nov. with $D$. incommunis Moret sp. nov. In the first case, we follow the results of the barcoding-based delimitation. In the three others, robust morphological characters support the separation of two species.

$1 /$ The re-examination of the type material has confirmed that D. palatus and D. denigratus are conspecific. We therefore proposed to synonymize $D$. palatus with $D$. denigratus, the former being a junior subjective synonym of the latter (see the discussion above, pp. 43-45).

2/ Dyscolus fucatus and D. robiginosus are sympatric in the Ayapungu massif. After examination of the type specimens and of new material collected in 2015-2017, we maintain the existence of two different species. The characters already mentioned in the original description (Moret 2005) are confirmed, and several more can be added. In $D$. fucatus the overall body size is bigger $(9.6-11.0 \mathrm{~mm}$ vs $8.6-9.5 \mathrm{~mm}$ in D. robiginosus); the upper surface is shinier, due to a shallower microsculpture with more oblong sculpticells; the antennae are longer; the elytra are less elongate (length from basal bead to apex / maximum width $=1.47-1.48$ in D. fucatus, $1.53-1.62$ in D. robiginosus); the fourth metatarsomere is thinner with much more asymmetrical apical lobes. Above all, the number of umbilicate setae along the lateral margin of the elytron is always higher (14-19 in D. fucatus, 10-12 in D. robiginosus).

3/ Dyscolus diopsis and D. oreas are closely related taxa, both adapted to extreme environments at the highest elevations of Northern Ecuador's superpáramos. Dyscolus diopsis has been found on several mountains (Cotacachi, Pichincha, Corazón, Illiniza, Cayambe, Guamaní, Antisana, Cotopaxi, Quilindaña, Llanganatis), generally above $4500 \mathrm{~m}$ a.s.l. (Moret et al. 2016). Being probably a southern vicariant of $D$. diopsis, $D$. oreas is a microendemic taxon, restricted to the connected superpáramos of Mt Chimborazo and Mt Carihuairazo. The morphological differences between D. diopsis and D. oreas, although slight, are constant and higher than the differences among the currently isolated populations of D. diopsis (Moret 2005). 
4/ We found strong morphological arguments to distinguish two new species, D. aquator Moret sp. nov. and $D$. incommunis Moret sp. nov., among the material of recent samplings in the montane forest of Western Ecuador (see above pp. 14-16), although the BIN algorithms give them the same number, therefore suggesting that they are conspecific.

\section{Species split by the BIN analysis}

In ten cases, a described and so far accepted species is split into two or more that two BINs: $D$. diopsis (4 BINs), D. rotundiceps (3 BINs), D. fusipalpis (Bates, 1891) (2 BINs), D. orthomus (Chaudoir, 1878) (4 BINs), D. oopteroides (Chaudoir, 1878) (5 BINs), D. lucifuga Moret, 1990 (2 BINs), D. alpinus (Chaudoir, 1878) (2 BINs), D. denigratus (3 BINs), D. hebeculus (2 BINs) and D. verecundus (3 BINs).

In the first seven cases, the species, as currently defined, proves to be monophyletic, and most of the included BINs correspond to high-altitude isolated populations that have probably begun a genetic differentiation. However, the morphological characters that could support the recognition of a species or subspecies status for these BIN-based entities are extremely weak (fusipalpis, orthomus, oopteroides) or could not be found at all (diopsis, rotundiceps, lucifuga, alpinus). We therefore decided to be conservative and not to split these species into different taxa. The more complex case of $D$. denigratus is discussed above (pp. 43-45).

In only two cases, those of $D$. hebeculus and $D$. verecundus, have we seen the need to split the existing taxon into two species, in agreement with the BIN analysis. Regarding D. verecundus Moret, 1998, please refer to the discussion in pp. 47-51 (D. verecundior Moret sp. nov.). The description of a new sibling species is postponed in the case of Dyscolus hebeculus (Bates, 1891). The holotype of this species was collected by Edward Whymper in 1880 "between Antisanilla and Piñantura, 11,000 feet"; in the vast subpáramo grasslands that extend west of Mt Antisana (Pichincha Province). The distribution area of $D$. hebeculus was later enlarged to the Cotopaxi Province (Moret 2005). Two specimens assigned to this species have been sequenced, one from Papallacta (COI voucher PM041-05, BOLD sequence SUM126-18), the other from the lower slopes of Mt Cotopaxi (COI voucher PM511, BOLD sequence SUM311-18), revealing a long molecular distance between them. As the type locality of D. hebeculus is just halfway between the sample sites of these two vouchers, a re-examination of the unique male holotype, held in the Bates Collection in Paris (MNHN), will be required to assign one of the barcoded specimens to the existing taxon, and describe the other as a new species.

\section{Acknowledgements}

This work was supported by 'Investissement d'Avenir' grants managed by Agence nationale de la Recherche (CEBA: ANR-10-LABX-25-01; TULIP: ANR-10-LABX-41), by the CNRS (SUMMITEX: PICS-06724 and MSHS-T USR 3414, 2015-2017; INSPYRAND: PEPS 2016, INSHS and Réseau National des MSH) and by the Pontificia Universidad Católica del Ecuador (projects N13456A, M13434, and MICCAA- N13419, 2016-2017). The Ecuadorian Ministerio de Ambiente provided research and collection permits numbers 005-12-IC-FAU-DNB/MA, 003-15-IC-FAU-DNB/MA, 005-14-IC-FAU-DNB/MA and 005-15-IC-FAU-DNB/MA. Special thanks are due to Álvaro Barragán, Washington Pruna, Emilia Moreno, María de los Ángeles Aráuz, Saúl Aguirre, Verónica Crespo, David Donoso, Ricardo Jaramillo and Priscilla Muriel for their help during the field work. We are greatly indebted to Carlos Ruiz Carreira (Universidad de La Laguna, Canarias) and Diego Marín (CISEC, Universidad Técnica Particular de Loja) who gave us access to the voucher specimens and barcodes of six Dyscolus species collected during their project "Estudio de la riqueza de especies y estructura filogenética en comunidades de carábidos a lo largo de un gradiente altitudinal en el Parque Nacional Podocarpus" (UTPL, 2013-2014). 


\section{References}

Bates H.W. 1891. Coleoptera. In: Whymper E. (ed.) Supplementary Appendix to Travels amongst the Great Andes of the Equator: 7-39. John Murray, London.

Bousquet Y. 2012a. Description of a new species of Platynus Bonelli from the Appalachian Mountains of eastern North America (Coleoptera, Carabidae). ZooKeys 163: 69-81.

https://doi.org/10.3897/zookeys.163.2295

Bousquet Y. 2012b. Catalogue of Geadephaga (Coleoptera, Adephaga) of America, north of Mexico. ZooKeys 245: 1-1722. https://doi.org/10.3897/zookeys.245.3416

Butcher B.A., Smith M.A., Sharkey M.J. \& Quicke D.L.J. 2012. A turbo-taxonomic study of Thai Aleiodes (Aleiodes) and Aleiodes (Arcaleiodes) (Hymenoptera: Braconidae: Rogadinae) based largely on COI barcoded specimens, with rapid descriptions of 179 new species. Zootaxa 3457: 1-232.

https://www.biotaxa.org/Zootaxa/article/view/zootaxa.3457.1.1

Camero E. 2003. Caracterización de la fauna de carábidos (Coleoptera: Carabidae) en un perfil altitudinal de la Sierra Nevada de Santa Marta, Colombia. Revista de la Academia Colombiana de Ciencias 27 (105): 491-516.

Chaudoir M. de 1859. Monographie du genre Colpodes MacLeay. Annales de la Société entomologique de France ( $3^{\text {e }}$ Série) 7: 287-364.

Chaudoir M. de 1878. Révision des genres Onychopterygia, Dicranoncus et Colpodes. Annales de la Société entomologique de France (5 Série) 8: 275-382.

Dejean P.F. 1831. Spécies général des Coléoptères de la collection de M. le comte Dejean. Tome cinquième. Méquignon-Marvis, Paris. https://doi.org/10.5962/bhl.title.8863

Edgar R.C. 2004. MUSCLE: multiple sequence alignment with high accuracy and high throughput. Nucleic Acids Research. https://doi.org/10.1093/nar/gkh340

Erwin T.L., Micheli C. \& Chaboo C.S. 2015. Beetles (Coleoptera) of Peru: a survey of the families. Carabidae. Journal of the Kansas Entomological Society 88 (2): 151-162.

https://doi.org/10.2317/kent-88-02-151-162.1

Folmer O., Black M., Hoeh W., Lutz R. \& Vrijenhoek R. 1994. DNA primers for amplification of mitochondrial cytochrome c oxidase subunit I from diverse metazoan invertebrates. Molecular Marine Biology and Biotechnology 3 (5): 294-99.

Gobbi M., Barragán A., Brambilla M., Moreno E., Pruna W. \& Moret P. 2018. Hand searching versus pitfall trapping: how to assess biodiversity of ground beetles (Coleoptera: Carabidae) in high altitude equatorial Andes? Journal of Insect Conservation 22 (3-4): 533-543.

https://doi.org/10.1007/s10841-018-0082-8

Kearse M., Moir R., Wilson A., Stones-Havas S., Cheung M., Sturrock S., Buxton S., Cooper A., Markowitz S., Duran C., Thierer T., Ashton B., Meintjes P. \& Drummond A. 2012. Geneious Basic: an integrated and extendable desktop software platform for the organization and analysis of sequence data. Bioinformatics 28 (12): 1647-1649. https://doi.org/10.1093/bioinformatics/bts199

Kozlov A., Darriba D., Flouri T., Morel B. \& Stamatakis A. 2019. RAxML-NG: a fast, scalable and user-friendly tool for maximum likelihood phylogenetic inference. Bioinformatics 35 (21): 4453-4455. https://doi.org/10.1093/bioinformatics/btz305

Lemoine F., Domelevo Entfellner J., Wilkinson E., Correia M., Dávila Felipe M., De Oliveira T. \& Gascuel O. 2018. Renewing Felsenstein's phylogenetic bootstrap in the era of big data. Nature 556: 452-456. https://doi.org/10.1038/s41586-018-0043-0 
Liebherr J.K. 1986. Cladistic Analysis of North American Platynini and Revision of the Agonum extensicolle Species Group (Coleoptera: Carabidae). University of California Publications in Entomology 106, Berkeley.

Liebherr J.K. 1992. Phylogeny and revision of the Platynus degallieri species group (Coleoptera: Carabidae: Platynini). Bulletin of the American Museum of Natural History 214: 1-115. Available from http://hdl.handle.net/2246/1625 [accessed 10 Apr. 2020].

Liebherr J.K. 1994. Identification of New World Agonum, review of the Mexican fauna, and description of Incagonum, new genus, from South America (Coleoptera: Carabidae: Platynini). Journal of the New York Entomological Society 102 (1): 1-55.

Liebherr J.K. 1998. On Rembus (Colpodes) brunneus MacLeay (Coleoptera: Carabidae, Platynini): redescription and relationships. Journal of Natural History 32: 987-1000.

https://doi.org/10.1080/00222939800770511

Liebherr J.K. \& Will K.W. 1996. New North American Platynus Bonelli (Coleoptera: Carabidae), a key to species north of Mexico, and notes on species from the southwestern United States. The Coleopterists Bulletin 50: 301-320.

Lorenz W. 2005. Systematic List of Extant Ground Beetles of the World. W. Lorenz private publication, Tutzing, Germany.

Lorenz W. 2019. CarabCat: Global database of ground beetles (version Oct 2017). In: Roskov Y., Ower G., Orrell T. et al. (eds) Species 2000 \& ITIS Catalogue of Life, 2019 Annual Checklist. Available from www.catalogueoflife.org/annual-checklist/2019 [accessed 10 Apr. 2020].

Martínez C. \& Ball G.E. 2003. Los Platynini (Coleoptera: Carabidae) de Colombia. Biota Colombiana 4 (2): $175-186$.

Maveety S.A. \& Browne R.A. 2014. Patterns of morphology in carabid beetles (Coleoptera: Carabidae) along a Neotropical altitudinal gradient. International Journal of Tropical Insect Science 34 (3): 157171. https://doi.org/10.1017/S1742758414000356

Moret P. 1989. Démembrement du genre Colpodes auctorum. I: Individualisation et définition des genres néotropicaux Dyscolus Dejean et Stenocnemion gen. nov. (Col. Caraboidea Platyninae). Bulletin de la Société entomologique de France 93 (5-6): 133-148.

Moret P. 1991. Contribution à la connaissance du genre Stenocnemion (Coleoptera, Harpalidae, Platyninae). Revue française d'Entomologie (N.S.) 13 (2): 65-74.

Moret P. 1996. Mise au point taxinomique sur le genre Dyscolus Dejean et description de cinq espèces nouvelles (Caraboidea, Harpalidae, Platynini). Bollettino del Museo regionale di Scienze naturaliTorino 14 (2): 491-503.

Moret P. 1998. Les Dyscolus de la zone périglaciaire des Andes équatoriennes (Coleoptera, Harpalidae, Platyninae). Bulletin de la Société entomologique de France 103 (1): 11-28.

Moret P. 1999. A contribution to the systematics of Neotropical Platynina. The supra-specific taxa of the Dyscolus complex (Coleoptera, Carabidae, Platynini). In: Zamotajlov D. \& Sciaky R. (eds) Advances in Carabidology - Papers dedicated to the Memory of Prof. O.L. Kryzhanovskij: 285-298. Krasnodar.

Moret P. 2005. Los Coleópteros Carabidae del Páramo en los Andes del Ecuador: Sistemática, Ecología y Biogeografía. Pontificia Universidad Católica del Ecuador, Centro de Biodiversidad y Ambiente, Monografía 2, Quito.

Moret P. 2019. Quatre nouvelles espèces de Dyscolus (Stenocnemion) de la Colombie et du Panama (Coleoptera, Carabidae, Platynini). Coléoptères 25 (6): 103-114. 
Moret P., Barragán A., Aráuz M.A. \& Gobbi M. 2016. Climate warming effects in the tropical Andes: first evidence for upslope shifts of Carabidae (Coleoptera) in Ecuador. Insect Conservation and Diversity 9 (4): 342-350. https://doi.org/10.1111/icad.12173

Perrault G.G. 1991. Etudes sur les Carabidae des Andes septentrionales. VIII. Démembrement du genre Glyptolenus Bates et description d'un genre voisin (Coleoptera). Nouvelle Revue d'Entomologie (N.S.) 8 (1): 43-59.

Ratnasingham S. \& Hebert P.D.N. 2007. BARCODING: Bold: The Barcode of Life Data System (http://www.barcodinglife.org). Molecular Ecology Notes 7 (3): 355-364.

https://doi.org/10.1111/j.1471-8286.2007.01678.x

Ratnasingham S. \& Hebert P.D.N. 2013. A DNA-based registry for all animal species: the Barcode Index Number (BIN) system. PloS ONE 8 (7): e66213. https://doi.org/10.1371/journal.pone.0066213

Riedel A., Sagata K., Surbakti S., Tänzler R. \& Balke M. 2013. One hundred and one new species of Trigonopterus weevils from New Guinea.ZooKeys 280: 1-150.https://doi.org/10.3897/zookeys.280.3906

Whitehead D.R. 1973. Annotated key to Platynus, including Mexisphodrus and most "Colpodes", so far described from North America including Mexico (Coleoptera: Carabidae: Agonini). Quaestiones Entomologicae 9: 173-217.

Will K.W., Liebherr J.K., Maddison D.R. \& Galián J. 2005. Absence asymmetry: the evolution of monorchid beetles (Insecta: Coleoptera: Carabidae). Journal of Morphology 264: 75-93.

https://doi.org/10.1002/jmor.10319

Manuscript received: 9 January 2020

Manuscript accepted: 24 March 2020

Published on: 15 May 2020

Topic editor: Nesrine Akkari

Section editor: Max Barclay

Desk editor: Pepe Fernández

Printed versions of all papers are also deposited in the libraries of the institutes that are members of the EJT consortium: Muséum national d'histoire naturelle, Paris, France; Meise Botanic Garden, Belgium; Royal Museum for Central Africa, Tervuren, Belgium; Royal Belgian Institute of Natural Sciences, Brussels, Belgium; Natural History Museum of Denmark, Copenhagen, Denmark; Naturalis Biodiversity Center, Leiden, the Netherlands; Museo Nacional de Ciencias Naturales-CSIC, Madrid, Spain; Real Jardín Botánico de Madrid CSIC, Spain; Zoological Research Museum Alexander Koenig, Bonn, Germany; National Museum, Prague, Czech Republic. 